atha șoḍaśayogādhyāyo vyākhyāyate | tatrekkavālādiṣoḍaśayogānāṃ nāmāny uktāni tājikabhūṣaṇe |

ikkavālenduvārākhyāv itthaśālam ataḥ pare |

isarāphaś ca naktam ca yamayā maṇaū tatah $\|$

kambūlaṃ gairakambūlam khallāsarakaraddake |

tato duhphālikutthaś ca dutthadabbìratambirau \|

kutthaś ca duruphaś caite yogāh șodaśa kirtitāḥ|

tājikācāryavaryaiś ca phalavijñānahetave \|

athetthaśālādiyogopayuktāḥ sūryādīnāṃ dīptāṃśā uktās tejaḥsiṃhena |

īkṣate 'rka iha pañcadaśāmsśair dīptakaiś ca ravibhir vidhur āraḥ|

aștabhir bhrgumrgānikatanūjau saptabhir guruśanī navabhiś ca || iti |

tājikasāre 'pi |

ravị śarābjais tapanaị śaśāniko lavair mahïjo vasubhiś ca bhāgaị̣| jñabhärgavau saptalavair nabhogair devejyamandau prayutim karoti $\|$

1 yogādhyāyo] yogādhyāyah B N G || vyākhyāyate] om. B N G || tatrekkavālādi] yatrekkavālādi $\mathrm{T} \quad 3$ itthaśālam atạ pare] itthaśālas tatah param K T M $\quad 7$ kutthaś] dutthaś $\mathrm{B}$ N G || duruphaś] durukaś G 8 -ācāryavaryaiś] -ācāryyaiś B a.c. N 10 'rka] om. N G a.c. 11 guru] guruh B N G 14 prayutiṃ] prayatim N G

3-8 ikkavāle- ... hetave] TBh 4.4-6 10-11 ìkșate ... ca] DA 8.9 13-14 ravih ... karoti] TS 88

(C) MARTIN GANSTEN, 2020 | DOI:10.1163/9789004433717_005

This is an open access chapter distributed under the terms of the CeC BY 4 -olicẹnse. 


\section{The Sixteen Configurations} Planets

Now the chapter on the sixteen configurations is explained; and the names of the sixteen configurations beginning with ikkavāla are described in Täjikabhūṣaṇa [4.4-6]:

Those called [1] ikkavāla and [2] induvāra, [3] itthaśāla and then [4] isarāpha, [5] nakta and [6] yamayā, [7] manaū and then [8] kambüla, [9] gairikambūla, [10] khallāsara, [11] radda, and then [12] duhphōlikuttha, [13] dutthotthadabira and [14] tambìra, [15] kuttha and [16] duruhpha: these are the sixteen configurations declared by the foremost of Tājika teachers for understanding the results [of the planets]. ${ }^{1}$

Next, the orbs of light of the sun and other [planets], employed in the configurations beginning with itthaśâla, are described by Tejạ̣siṃha [in Daivajñālamkrti 8.9]:

Here the sun aspects within an orb of light of fifteen degrees, the moon within twelve, Mars within eight, Venus and Mercury within seven, and Jupiter and Saturn within nine.

And in Tājikasāra [88 it is said]:

Within fifteen degrees the sun; within twelve, the moon; within eight degrees, Mars; within seven degrees, Mercury and Venus; and within nine, Jupiter and Saturn make a joining.

1 For the Arabic antecedents of these names and their transmission, see the Introduction. Sanskritized forms vary considerably within the text and across witnesses. For the sake of intelligibility, the nomenclature has been standardized in the translation, using the variants most frequently found and/or closest to the Arabic originals. The most common variant forms are noted in the Glossary. 
atra pañcadaśabhir aṃśaị raviḥ prayutim vakṣyamāṇetthaśālādiyogam karotīty arthah | evaṃ sarvatra | praśnavaiṣnave rāhor api dvādaśa dīptabhāgā uktāḥ ||

athekkavālenduvārau | tatrekkavālenduvārayor lakṣaṇam uktaṃ saṃjñātantre |

cet kaṇțake pañaphare ca khagāh samastāh

syād ikkavāla iti rājyasukhāptihetuh |

āpoklime yadi khagāh sa kilenduvāro

na syāc chubhạ̣ kvacana tājikaśāstragītah || iti |

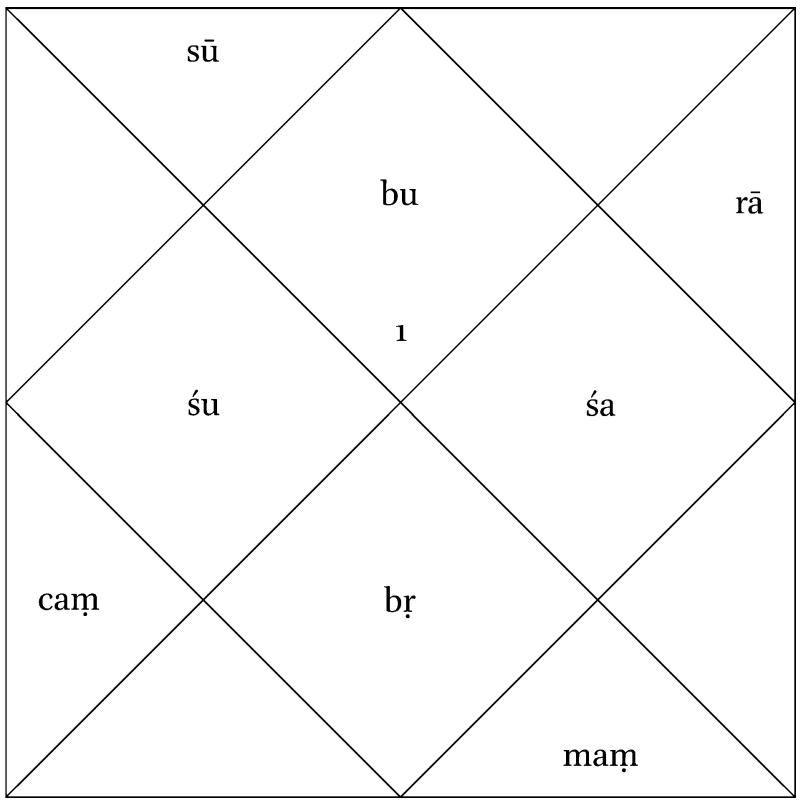

ikkavālayogaḥ

5 tantre] taṃtraivam B N G 8 sa kilenduvāro] sakaleṃduvāro B; sa keleṃduvāro K T

6-9 cet ... gītah] ST 2.17 
That is, the sun makes a joining, [meaning] a configuration such as the itthaśa $a$ a described below, within fifteen degrees; and so on throughout. In the Praśnavaiṣnava, Rāhu, too, is assigned an orb of twelve degrees.

\subsection{The Ikkavāla and Induvāra Configurations}

Next, ikkavāla and induvāra; and the definitions of ikkavāla and induvāra are stated in Samjñātantra [2.17]:

If all the planets are in an angle or a succedent house, that is ikkava $l a$, causing attainment of dominion and happiness. If the planets are in a cadent house, that is induvāra, never praised as good in the Tājika science.

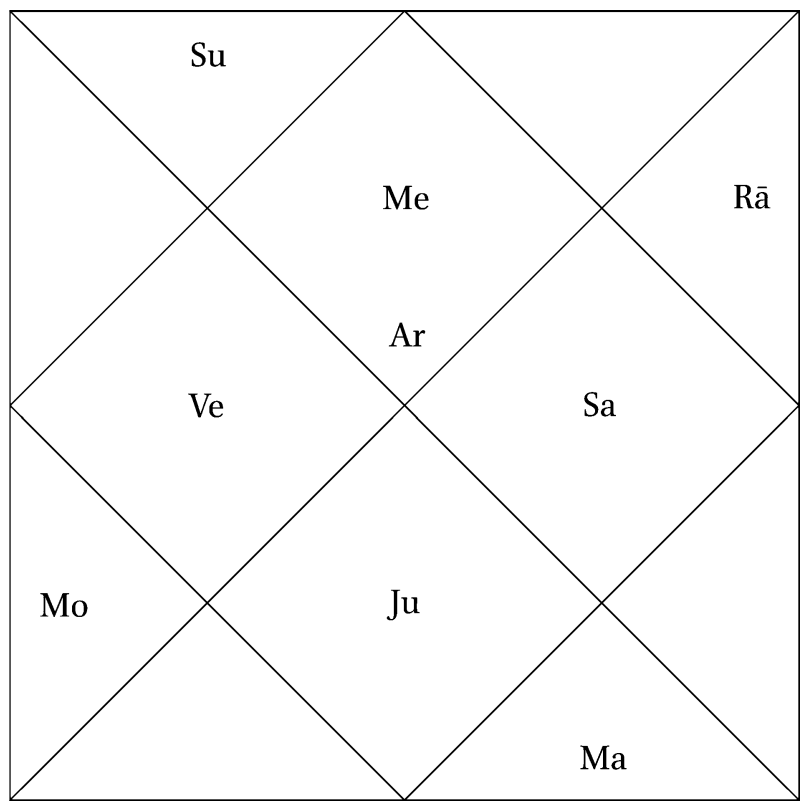

The ikkavāla configuration 


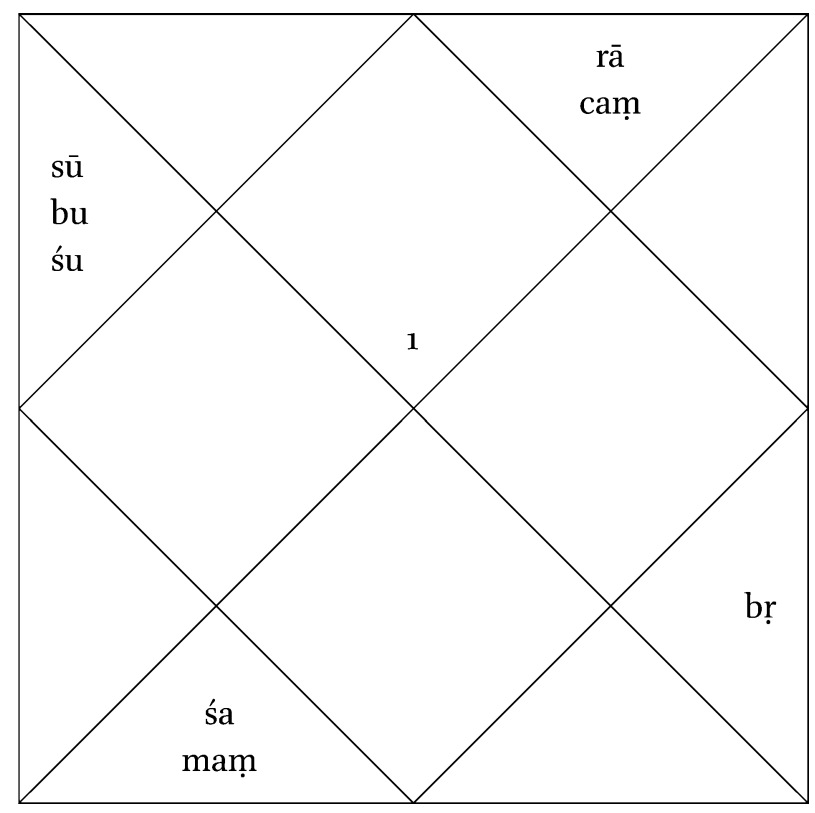

induvārayogah

atra varșapraveśe ikkavālayogotpattau rājyasukhayor labdhị̣ kulānumānena vācyā | varșārișțe 'py ariștabhango vācyah | kvacana varșapraveśamāsapraveśādau yadā kendrāpoklimasthā grahāḥ paṇapharāpoklimasthā vā syus tadā ko 'pi yogo na sambhavet | sarve grahā dvitrișv api kendrādișu sthitā yogakartārojñeyāḥ iti jīrṇațīkākṛt | yādavenaitau yogau anyathaiva kathitau |

\section{kendrasthitadvitayarāśigayoḥ khadhāmnor}

drșțis tadā nigadito 'tra sa ikkavālah |

apoklimopagatakendragayor yadi syād

yogas tadā munivaraiś ca sa induvāraḥ || iti |

2 arișța] ariștya $\mathrm{N} \|$ praveśa] praveśo B N G a.c. 3 yadā] tu add. G 5 ț̣ikākṛt] țīkāt B N G a.c. || kathitau] kathitam $\mathrm{G} \quad 6$ kha] sva B K M

6-9 kendra ... induvāraḥ] TYS 6.5 


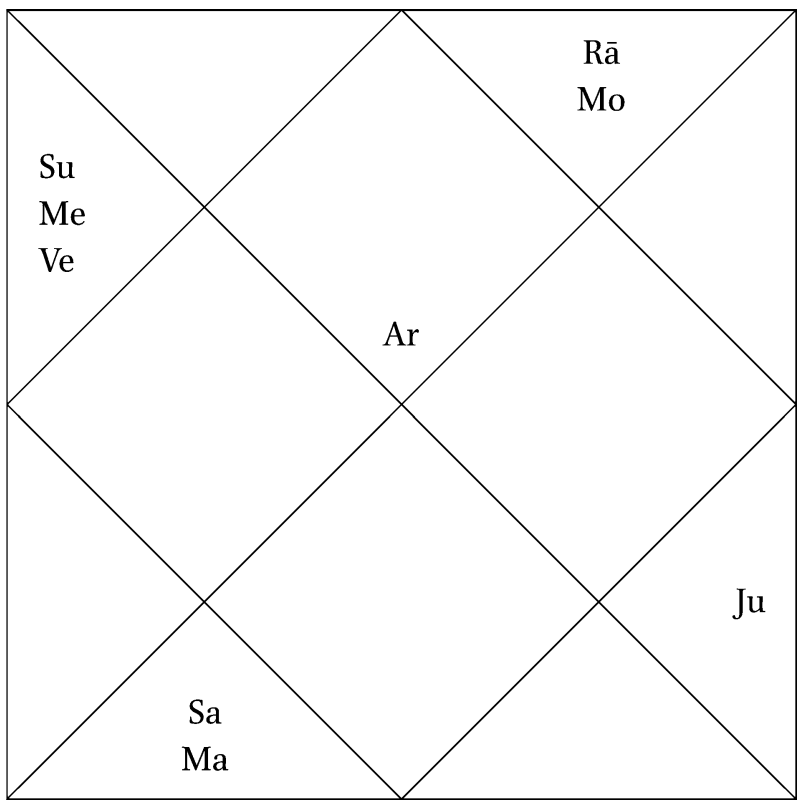

The induvāra configuration

Here, if the ikkavāla configuration arises in the revolution of the year, the attainment of dominion and happiness should be predicted in accordance with [the native's] family community; and if a misfortune [is expected] in that year, the reversal of that misfortune should be predicted. But if, in any revolution of the year or month and so on, the planets occupy angles and cadent houses, or succedent and cadent houses, then no [such] configuration can occur. So says the ancient commentator: 'All the planets, even occupying two or three angles and so on, should be understood to cause the [ikkavāla] configuration.' [But] Yādava describes these configurations quite differently [in Täjikayogasudhānidhi 6.5]:

[If there is] an aspect between planets placed in signs that occupy two angles, then the great sages call that ikkavāla; if the configuration is between [planets] placed in a cadent house and an angle, [respectively], then that is induvarra.

2 Or 'the commentator [called] Jìrna' or 'the commentator on [the work of] Jirnna'. See the Introduction. 
dvayor eva grahayoh kendrapaṇapharasaṃsthayor dṛșțau satyām ikkavālayogaḥ | dṛșțau satyāṃ kendrāpoklimasthayor dvayor eva grahayor induvārayoga iti yādavamatam | atra dīptāṃśair dṛșțau yogāḥ sambhavanty ato yādavokta eva pakṣaḥ sādhīyān iti cen na | yato yamayāyoge sarvais tājikakartṛbhir dṛsțyabhāva udāhṛto 'sti | iti ikkavālenduvārau ||

athetthaśālaḥ | tac ca vartamānaparipūrṇabhaviṣyanmuthaśilabhedena tridhetthaśālayogah | tatra vartamānamuthaśilayoge lakṣaṇam uktaṃ tājikālaṃkāre |

dṛ̦țau satyāṃ proktadīptākhyabhāgair

mandāt khețac chïghrakhețo yadālpaḥ

amśais tulyậ kimcid ünas tadettha-

śālo yogo mūthaśllạ̣ sa eva || iti |

atretthaśālādiyogeṣu grahāṇāṃ śīghragatvaṃ mandagatatvaṃ ca spaștagatyā jñeyam | atra kecic chīghramandagrahayor ekarāśisthayor eva muthaśilayogaḥ na navapañcādibhinnarāśau | yatạ̣ samarasiṃhena madhyamādhamakambūlalakșaṇe

meșasthe 'bje śaninā karkasthe bhübhuvā striyām kavinā | makarasthe guruñà saha minasthe jñena na śubhạ̣ ca \|

1-3 ikkavāla ... dṛșțau] om. B N 3 yogāh] yogah B N G $\quad 5$ dṛsṭyabhāva] dașṭābhāva N; daștyabhāva G 6 bhavișyan] bhavișya K M \| muthaśila] munthaśila K 11 tulyah] svalpah B N G a.c. 15 na] om. B N G M 16 lakṣaṇe] kṣaṇe N 18 makarasthe] makarasthena K T \| jñena] jñe M

17-18 meșasthe ... ca] Also quoted in full in PK ad ST 2.51, which contains part of the same stanza. 
The ikkavāla configuration is when there is an aspect between just two planets occupying angles or succedent houses; the induvāra configuration is when there is an aspect between just two planets occupying an angle and a cadent house: this is Yādava's opinion. If [anyone should say] that because [all] configurations come to be when there is an aspect within the orbs of light [of the planets involved], Yādava's position is better, [we say]: not so, because the yamayā configuration is defined by all Tājika authors as an absence of aspect. ${ }^{3}$ This concludes the ikkavāla and induvāra.

\subsection{The Itthaśāla Configuration}

Next, itthaśāla; and the itthaśāla configuration is threefold, by the distinction between an ongoing, perfected, and future mutthaśila. ${ }^{4}$ Among them, the definition of an ongoing mutthaśila configuration is stated in the Tājikālaṇkāra:

In an aspect occurring within the [previously] described orbs of light, when the swifter planet is less than the slower planet in degrees [of longitude], equal [or just] slightly less, then the configuration is [called] itthaśála; mutthaśila is the same.

The swiftness or slowness of the planets in these configurations beginning with itthaśăla should be known from their true motions. Now, some [say that] a mutthaśila configuration pertains only to a swifter and a slower planet occupying a single sign, not when they are nine and five signs apart and so forth, ${ }^{5}$ because Samarasiṃha presents a mutthaśila configuration as [taking place] in a single sign, not in different signs, in defining a middling/inferior kambūla in this verse [from the Tãjikaśāstra]:

If the moon is in Aries with Saturn, in Cancer with Mars, in Virgo with Venus, in Capricorn with Jupiter, or in Pisces with Mercury, [the result] is not good.

3 Or: 'in the absence of an aspect'. In either case, Balabhadra's argument does not hold up, as even yamaya does require an aspect - in fact, two aspects - within the respective orbs of light of the planets; cf. section 3.6.

4 Itthaśāla and mutthaśila (from Arabic ittișāl and muttașil, respectively) are typically used entirely synonymously.

5 In a trine aspect, counting inclusively, planet $A$ will be in the fifth sign from planet $B$, while planet $\mathrm{B}$ is in the ninth sign from planet $\mathrm{A}$. 
iti padyenaikarāśau muthaśilayogo 'bhihito na bhinnarāśau | iti cen na yatas tena tatraiva nīcagayor grahayor itthaśālaḥ kāryanāśakaḥ proktaḥ | tad yathā |

yadi nìco nīcena ca muthaśilakārī tathā ripur dvișatā | tadvat tat kambūlaṃ candro 'pi vināśako 'muṣmin || iti |

atra muthaśilakārinoror grahayor ekaṃ nīcaṃ na sambhavati | trayāṇāṃ lagneśakāryeśacandrāṇāṃ tu sutarāṃ na sambhavati | tasmād ekag̣̣hagayor eva muthaśílayoga iti vyāptir gataiva | uktaṃ ca tejaḥsiṃhena |

uktāṃśakāntaradrguttham apītthaśāla-

kambūlakạ̣ ca prthagṛș̣agayor dvayoh syāt | iti |

anye punar āhuh | rāśicakre śīghragrahasyāgre yadā mandagraho bhavati tadetthaśālayogo netarathā | etad avicāritaramaṇīyam | yatạ̣ samarasiṃhena uttamottamakambūlodāharaṇe ravibhaumābhyām yathā meșe ity anena

candräparau yadi mithạ̣ svagṛhoccasamsthau meșe yathā kujaravì tad atīiva śastam |

ity anena ca tejaḥsiṃhenāpi meșasthayor arkabhaumayoḥ karkasthena candreṇa sahetthaśālayoga uktah | tatra meșasthayor arkabhaumayor mandagayoḥ śīghragaś candro agre bhavati na tu pṛșțhe | tasmāc chīghra-

1 padyenaika] yadyenaika G 4 kārī] yathārī add. N G a.c. \| tathā] scripsi; yathā B N G K T M 5 tadvat] madvat G $\|$ tat] om. B N G 7 gṛhagayor] grahayor B G a.c.; graharyor N; grahayogar G p.c. 8 yoga] yogo B N G \| vyāptir] vāpti B N G 10 pṛthagṛkṣa] pṛthagṛharkṣa N p.c.; pṛthagarkșa K T M 12 netarathā] netarayā B N || avicārita] avicāritaṃ B N K T \| ramaṇìyam] maraṇìyạ̣ G a.c.; ramaraṇīyaṃ G p.c.

9-10 uktāṃśakā- ... syāt] DA 9.10 $\quad$ 15-16 candrāparau ... śastam] DA 9.7

4-5 yadi ... 'mușmin] Also quoted with minor variations ( $p \bar{a} d a$ c reads tat kambülam neștam $)$ in PK ad ST 2.52, which paraphrases the same stanza. My emendation is supported by the reading of the PK. 
If [anyone says] thus, [we say]: not so, because [Samarasimha] himself in that same [Täjikaśāstra] declares that an itthaśála between two planets in their fall destroys the matter sought, as follows:

If a [planet] in its fall forms a mutthaśila with [another planet] in its fall, or an enemy with an enemy, that kambüla is the same: in this [configuration], the moon destroys [the matter]. ${ }^{6}$

Regarding this, it is not possible for two planets forming a mutthaśila to have a single sign of fall; and it is most certainly not possible for three [planets]: the ruler of the ascendant, the ruler of the matter sought, and the moon. Therefore, the [supposed] rule that a mutthaśila configuration pertains only to [planets] occupying a single sign is revoked. And Tejahsimha says [in Daivajñälaṃkrti 9.10]:

An itthaśăla [or] kambūla produced by an aspect within the degrees stated [for the orbs of light] may take place between two [planets] occupying different signs.

Others, moreover, say that there is an itthaśa la configuration when the slower planet is ahead of the swifter planet in the zodiac, and not otherwise. This is agreeable [only] to the unreflecting, because in illustrating a superior/superior kambūla, Samarasiṃha in the [verse from the Täjikaśāstra] beginning 'Like the sun and Mars in Aries', and also Tejahssiṃha in this [verse, Daivajñālaṃkrti 9.7]:

If the two [planets] other than the moon occupy each other's domicile or exaltation, like Mars and the sun in Aries, that is exceedingly fortunate.

- describe an itthaśāla configuration of the sun and Mars in Aries with the moon in Cancer. In that [configuration], the swifter moon is ahead of the slower sun and Mars placed in Aries, not behind them. Therefore it should be understood that, of the swifter and the slower planet, which is ahead

6 'The same' presumably means 'as in the previous verse', that is, not good. These two stanzas from Samarasiṃha's lost work are also quoted by Viśvanātha in his commentary on Samjiñätantra $2.51-52$, but with the phrase 'that kambüla is not good' in the place of 'that kambüla is the same'. 
mandagrahayor madhye agrasthatvam prșțhasthatvam rāśicakre yathāsambhavaṃ jñeyam | ata eva maṇaūyoge

yadi vakraḥ saurir vā síghrasyāgre sthito 'thavā prșțhe| paśyamiś caturthasaptamadrștyā vāthaikarāśisthaḥ \|

ity anena padyena samarasiṃhena śīghramandayor agraprșțhasthatvam yathāsambhavam eva pradarśitam | sarvayogeșv api muthaśilavicāro grahāṇām ekarāśigānāṃ bhinnarāśigānām api bhavaty eveti spașțam abhihitam || atra svadīptāṃśair dvādaśāṃśair vā muthaśilayogādayo vicāraniiyā ity uktạ̣ tājikatilake |

svadīptabhāgai ravibhāgakair vā yogā vicāryā muthaślamukhyāḥ| iti |

atha paripūrṇamuthaśilalakṣaṇam uktam yogasudhānidhau |

vikalikākalikādalahīnakaś carakhago 'lpajavād api vā samaḥ| muthaśilam sakalam sakalaṃ phalam phalatiyad yavano munirāạjagau \|

bhavișyanmuthaśilayogalakṣaṇam uktaṃ vāmanena |

rāśyantagaḥ śighragatịh sthirasya bhāgān vivikșuh pararāśigasya | yadā bhavet tam pravadanti yogam eșam bhavișatphaladam sadaiva \|

samarasiṃhamate vartamānamuthaśilayogo 'yam | bhaviṣyanmuthaśilalakșaṇam uktaṃ tenaiva |

1 agrasthatvaṃ pṛșțhasthatvaṃ] agraprșțhastham B N G $\quad$ 1-4 cakre ... rāśi] om. B N G a.c. 2 ata] etad KTM 4 vāthaika] tathaike KT; tathaika M 5 samarasiṃhena] samarasiṃhe B NG a.c. 6 eva] e B \| vicāro] vicā NG a.c. 7 abhihitam] ca add. KT M 8 dīptāṃśair] dīptāṃśaṃ B N G 8-10 dvādaśāṃśair ... bhāgai] om. B N G a.c. 12 javād] javār B N G \| api] atha K T M 13 sakalaṃ²] saphalaṃ K \| phalaṃ] tadā K \| phalati] kalati B N G a.c. || yad] tad K || yad yavano] padmavano G p.c. 15 vivikșuh]] scripsi; vivakșuh B N G K T M 17 'yam] bhaviṣyanmuthaśilayogoyaṃ add. K T; bhavișyanmuthaśillayogoyaṃ add. M

12-13 vikalikā ... jagau] TYS 6.7

7 The sentence presumably continues into the following stanza. The aspects mentioned correspond to the square, opposition and conjunction.

8 Because most of the sixteen configurations are more or less complex variations on applying and/or separating aspects between two or more planets, Balabhadra considers application or mutthaśila as an integral part of these other configurations. 
and which behind in the zodiac depends on the circumstances. That is why, in [describing] the manaū configuration, Samarasiṃha in this verse [from the Tajikaśāstra] demonstrates that the swifter and slower planets' positions ahead or behind each other depend on the circumstances:

If Mars or Saturn is placed ahead of the swifter [planet] or behind, aspecting [it] by the fourth- or seventh-[sign] aspect or occupying the same sign ... ${ }^{7}$

And it is made clear that in all configurations, the consideration of mutthasila pertains both to planets occupying a single sign and to those occupying different signs. ${ }^{8}$

On this matter, it is stated in the Tajjikatilaka that the configurations beginning with mutthaśila should be considered [when occurring] either within [the planets'] own orbs of light or within twelve degrees:

Within their own orbs of light or within twelve degrees, the configurations beginning with mutthaśila should be considered.

Next, the definition of a perfected mutthaśila is stated in [Täjika]yogasudhānidhi [6.7]:

[When the longitude of] the swifter planet is a second of arc, or half a minute of arc, less than [that of] the slower one, or equal [to it, that] completed mutthaśila bears complete fruit, as the lord of Yavana sages has declared.

Vāmana states the definition of a future mutthaśila configuration:

When the swifter [planet], situated at the end of a sign, is about to enter the degrees [of the orb of light] of the slower one placed in the next sign, that configuration is called impending and always gives future results. 9

[But] in Samarasimpha's opinion, this is an ongoing mutthaśila configuration. He gives [this] definition of a future mutthaśila [in the Tājikaśāstra]:

9 That is, it signifies events to take place at some future time. This distinction is meaningful for instance in interrogational astrology, where events past, present and future (with respect to the time of the client asking a question) may all be of relevance. 
yady uktabhāgato 'sau hīnāmśair mandaprșțhato bhavati | tan muthaśilam bhavișyad gaṇañyam kāryasaṃsiddhyai \|

atretthaśālayoge prșțhasthe śīghre vakrini satītthaśālaphalābhāvah | agrasthe mande vakriṇi satītthaśālaviśeșa iti sampradāyayuktị̣ | vartmanānamuthaśilodāharaṇam āha yādavaḥ |

vrścike bhavati bhūsutas tanau bhāgașoḍaśa ino harau dvayam | vā samāmśakamitau tadālpakād rājyalabdhir apare khilāḥ svayam \|

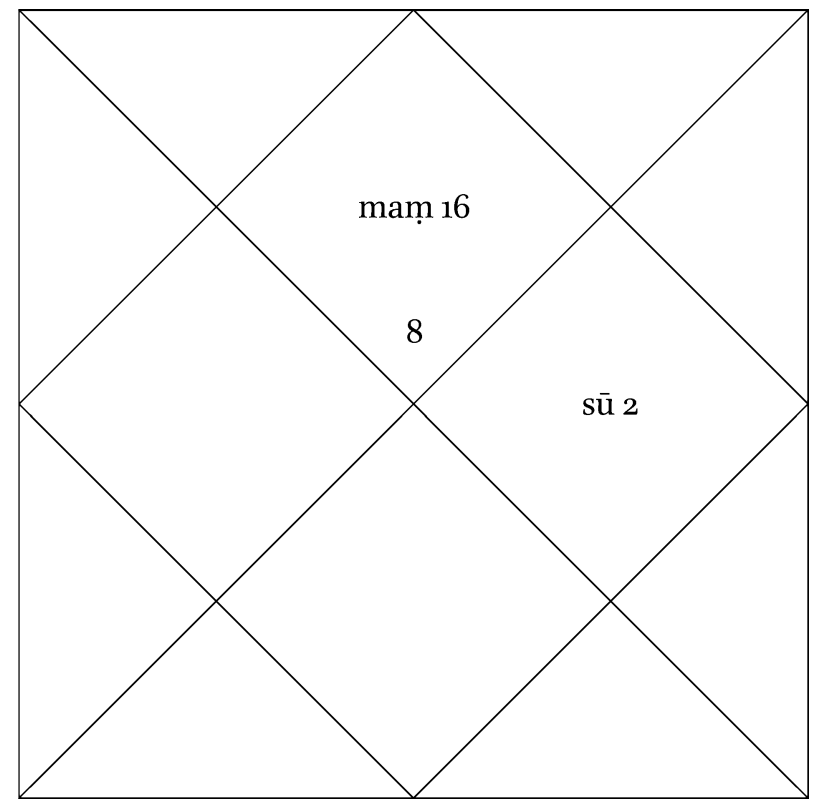

vartamānamutthaśilayogah rājyalābhapraśnah

2 bhaviṣyad] bhavișya B N G a.c. 3-4 atretthaśāla ... yuktị̣] om. B N G a.c. 4 vakriṇi] cakrini $\mathrm{G} \|$ satītthaśāla] phala add. K T M \| viśeșa] viśeșe $\mathrm{G} \quad 6$ harau] hatau N $\quad 7$ samāṃśaka] samāṃka B N G || tadālpakād] scripsi; tadālpadā B N G; tadālpikā KT M \| khilāḥ] khilā M || svayam] śrayaṃ G p.c.; tv ayaṃ K T M

6-7 vṛścike ... svayam] TYS 6.10 
If this [swifter planet] is behind the slower one with less degrees than the degrees declared [as the orb of light], ${ }^{10}$ that should be reckoned a future mutthaśila, [working] to accomplish the matter sought.

In this itthaśâla configuration, if the swifter planet, placed behind [the slower one], is retrograde, there are no itthaśa ala results; [but] if the slower planet, placed ahead [of the swifter one], is retrograde, it is a variety of itthaśăla: this is the reasoning of the [Tājika] tradition. ${ }^{11}$ Yàdava gives an example of an ongoing mutthaśila [in Täjikayogasudhānidhi 6.10]:

[If] Mars is in Scorpio in the first house with sixteen degrees, the sun in Leo [with] two, or with the same number of degrees, then presently [the querent] will achieve dominion. Other [examples should be] supplied by [the reader] himself.

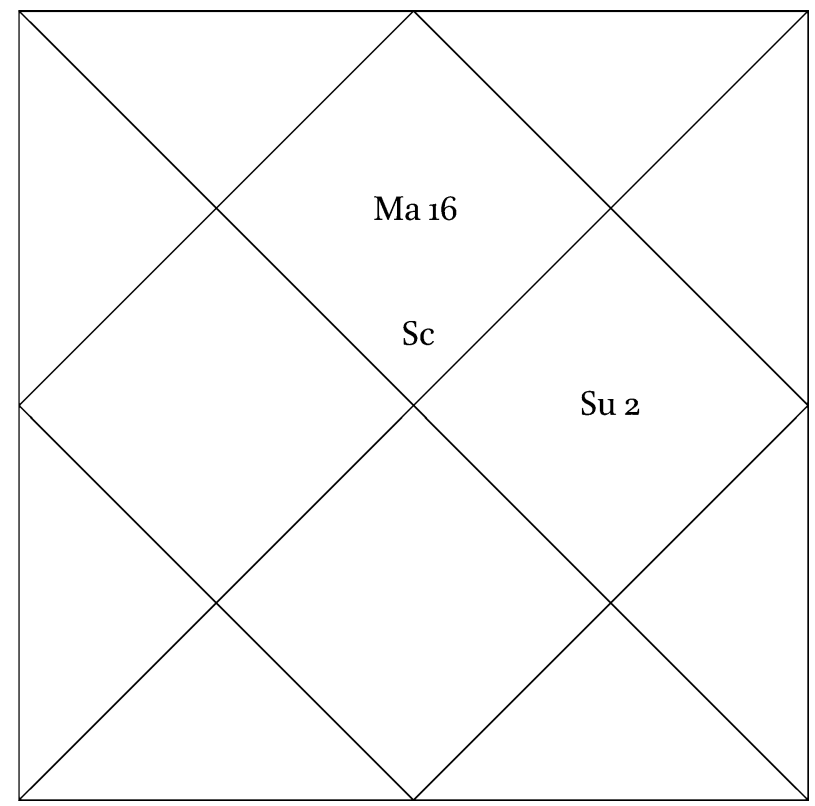

An ongoing mutthaśila configuration: question on gaining dominion

10 That is, if the swifter planet's longitude is so much less than the slower planet's that the distance exceeds the stipulated orb of light.

11 Because in the former case the aspect will never perfect, whereas in the latter, it will. 
atha pūrṇamuthaśilodāharaṇaṃ jīrṇatājike |

strīlābhasya praśne karkavilagnam śaśi vrșe dvibhāgāḍhyaḥ |

sāștādaśakalikạdhyaḥ kaurpye mando dvibhāgamitạ̣|

ekonaviṃśatikalāsahito yam pūrṇaphaladạ̣ syāt \|

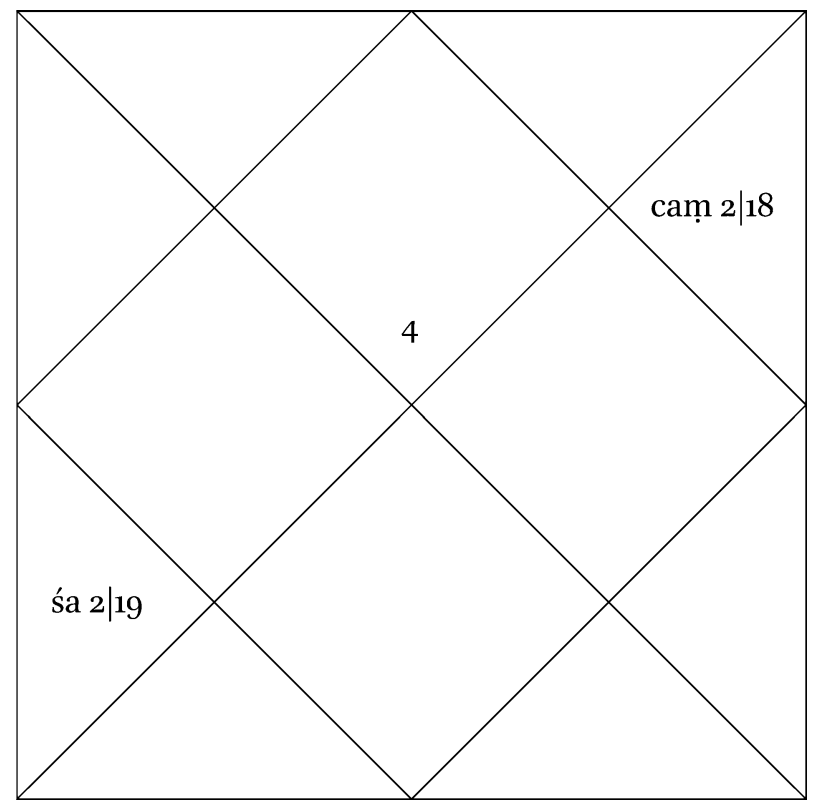

pūrṇamutthaśilayogaḥ strīlābhapraśnah

atha varșapraveśe yadi ko 'pi pṛcchati mamāsmin varșe strīlābho bhaviṣyati na veti | evamuvidhe praśne lagneśakāryeśayoḥ paripūrṇetthaśāle strīlābho 'vaśyaṃ vaktavyah | evam agre sarvatra jñeyam || atha rāśyantarāśyādisthitagrahetthaśālayogodāharaṇam |

2 bhāgāḍhyaḥ] bhāgādyaḥ N G a.c.; bhāgagaḥ K M 3 kaurpye] kāryye M 5 pṛcchati]

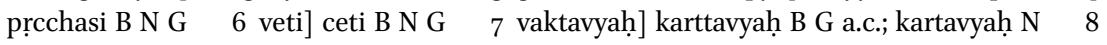
-śālayogod-] -śālod- K T M

2 strī ... bhāgāḍhyah] This half-stanza deviates from the standard varieties of āryā metre: its eight feet (gana) consist of four morae ( $m \bar{a} t r a \overline{)}$ ) each, except for the seventh, which has five morae, making 33 in all. The same pattern recurs in a number of quotations below, some unattributed and others attributed to Samarasimpha. 
Next, an example of a perfected mutthaśila [is given] in the Jirnnatājika:

In a question about obtaining a wife, Cancer is the ascendant; the moon is in Taurus at two degrees and eighteen minutes [of longitude]; Saturn is in Scorpio at two degrees and nineteen minutes. This [configuration] will give complete results.

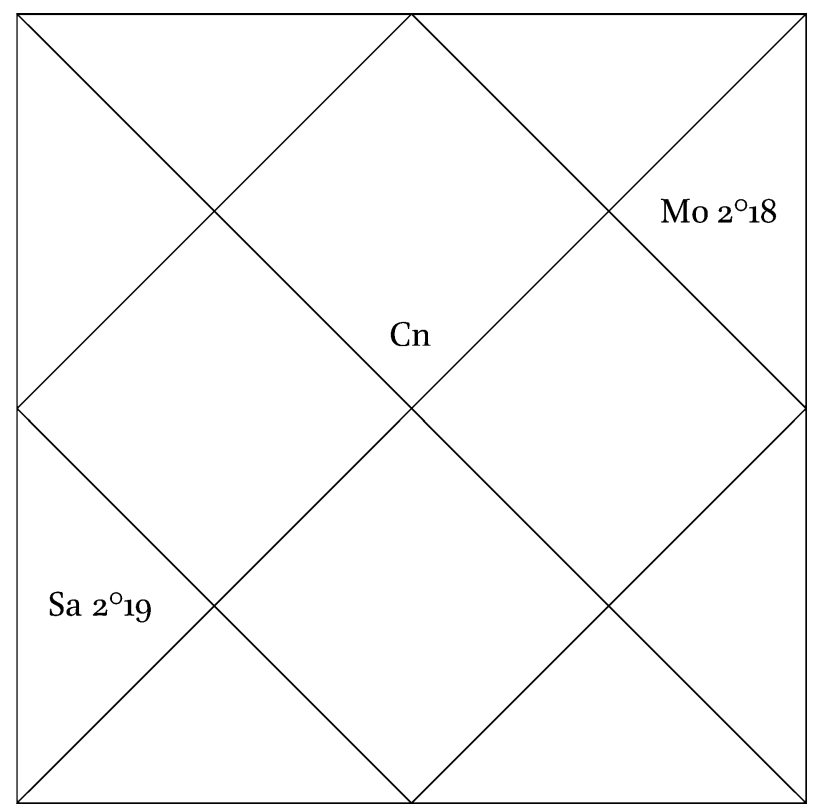

A perfected mutthaśila configuration: question on gaining a wife

Thus, in a revolution of the year, if someone asks, 'Will I obtain a wife this year or not?', [or] in such a question, ${ }^{12}$ if the rulers of the ascendant and of the matter sought form a perfected itthaśa la, the obtainment of a wife should be predicted with certainty. It should be understood likewise in all other [areas].

Next, an example of an itthaśāla configuration between planets occupying the end of a sign and the beginning of a sign: ${ }^{13}$

12 I take this to mean that the astrological figure being judged to answer the question may be either one cast for the revolution of the year (varșakundalī) or one cast for the actual time of the client asking the question (praśnakundalī).

13 Presumably continuing from the Jirnatäjika. 
vrṣalagnaṃ lābhasya praśne kumbhe 'ntyabhāgagaḥ śukraḥ|

vedāmśamito mine gurur evaṃ mutthaśilayogạ̣ $\|$

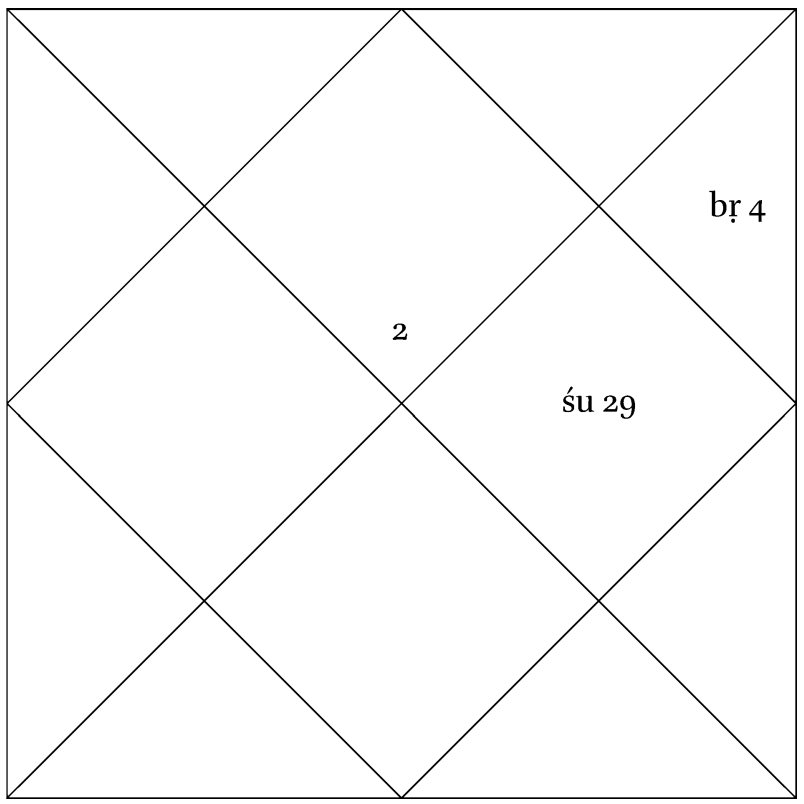

prakārāntareṇa mutthaśilayogaḥ lābhayogapraśnaḥ

atha bhavișyanmuthaśilodāharaṇam |

tulāvilagne bhrgujah śarāṃśaiḥ karke 'dricandraị kṣitijo 'ntyarāśau| dhanasya lābhe kathito bhavisyadyogah sakhe bhāviphalapradātā \|

1 lagnam] lagne $\mathrm{N} \quad 2$ mutthaśilayogah] muthaśilo yogaḥ B N; muthaśilayogaḥ G 4 'dri] dvi B N G 5 lābhe] lābhạ̣ B N G

4-5 tulā ... pradātā] TYS 6.11

2 mutthaśilayogah] Although the earliest text witnesses support a slightly different reading, the geminated mutthaśila, being closer to the Arabic muttașil, appears somewhat more likely to be the original form. With the loss of gemination, the compound may have been broken up to preserve the metre. 
In a question on gain, Taurus is the ascendant; Venus is in the last degree of Aquarius, [and] Jupiter is in Pisces at four degrees: thus [there is] a mutthaśila configuration.

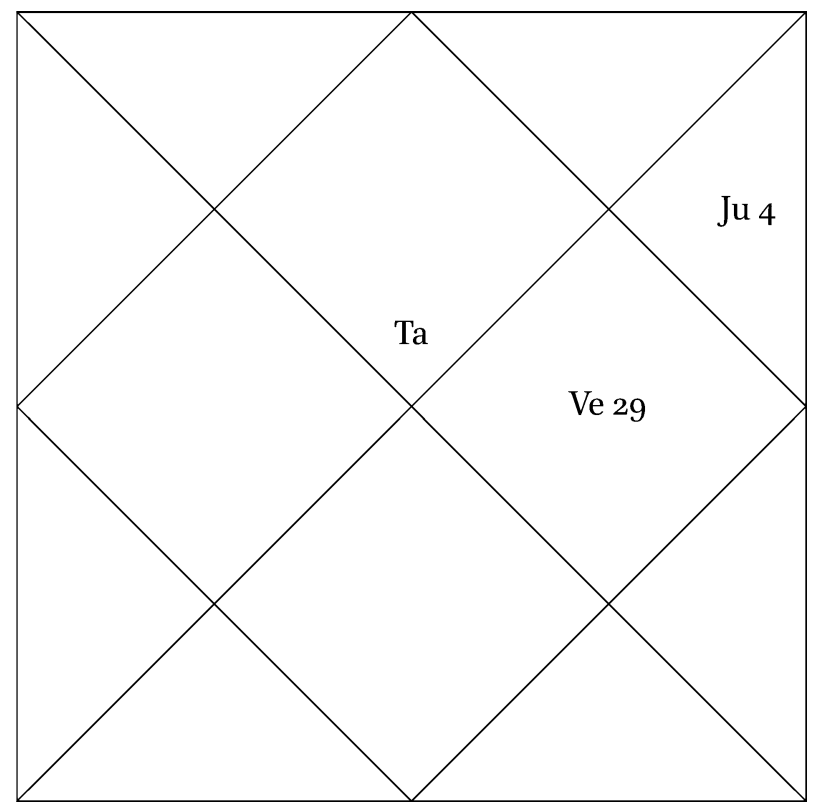

A different kind of mutthaśila configuration: question on configuration for gain

Next, an example of a future mutthaśila [from Täjikayogasudhānidhi 6.11]:

With Libra ascending, Venus is in Cancer at five degrees, Mars in Pisces with seventeen degrees. This, friend, is said to be a future configuration for gain of wealth: it gives results yet to come. 


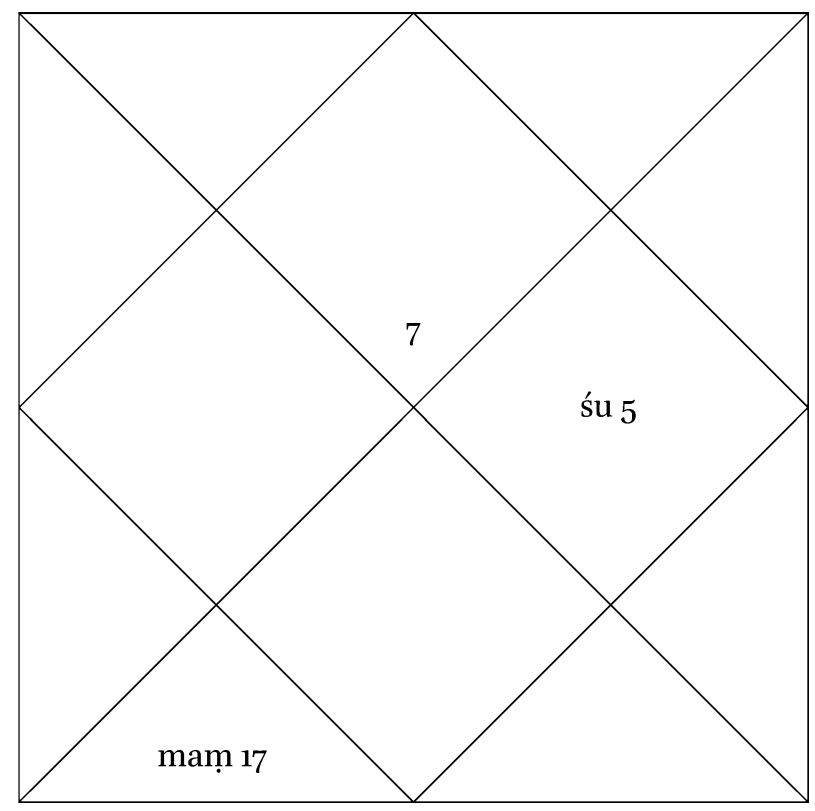

bhaviṣyanmutthaśilayogạ̣ dhanalābhapraśnah

athetthaśāle phalanirdeśaprakāra uktaḥ saṃjñātantre |

lagneśakāryādhipatatsahāyā yatra syur asmin patisaumyadṛ̦țe | tadā balāḍhyam kathayanti yogaṃ viśeșatạ̣ snehadrśeti santah \|

sahāyo nāma mitram | lagneśạ̣ lagneśamitraṃ kāryeśạ̣ tanmitram ete catvāro yatra bhāve syus tasmin bhāve patisaumyadṛ̦țe sati balī yogah | 5 atha bhāvadaśāsahamatasīramuthahābdeśādayo 'pi yatra bhāve syus tasmin bhāve patisaumyadṛște sati teșāṃ sabalatvaṃ syād iti samarasiṃhațịkākṛt |

3 sneha] saumya B N G 4-5 lagneśah ... catvāro] om. B N G 4 mitraṃ kāryeśaḥ] mitrāryeśaḥ M $\quad 6-7$ atha ... tịkākṛt] om. B N G 7 sabalatvaṃ] sabala T; sabalaḥ M

2-3 lagneśa ... santah]] ST 2.21 


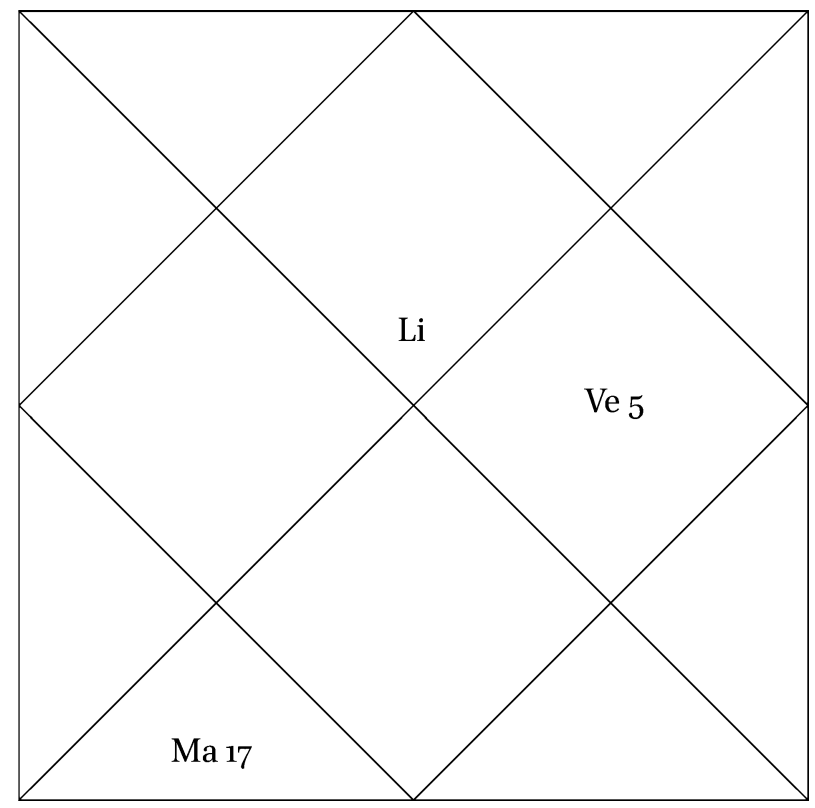

A future mutthaśila configuration: question on gaining wealth

Next, a method for ascertaining the results of an itthaśāla is described in the Samjiñātantra [2.21]:

If [the place] where the ruler of the ascendant, the ruler of the matter sought and their helpers are [located] is aspected by its ruler and benefics, the wise call the configuration powerful, particularly if [the planets aspect] by a friendly aspect.

A helper means a friend. The ruler of the ascendant, its friend, the ruler of the matter sought and its friend: when the house where these four are [located] is aspected by its ruler and benefics, the configuration is strong. And when the house where the rulers of a house, a period, a sahama, the tāsira, the munthahā, the year and so on are [located] is aspected by its ruler and benefics, they [too] are strong: so says the commentator on [the Tājikaśāstra by] Samarasiṃha. [Continuing from Samjjãātantra 2.22-23:] 
svarkșādisatsthānagatah śubhaiś ced yutekșito 'bhūd bhavitāthavāste | tadā subham prāg abhavat supūrnam agre bhavișyaty atha vartate ca \| vyatyastam asmād viparïtabhāve 'theșțarkșato 'niștagrham prapannaḥ| abhūc chubhaṃ prāg aśubham tv idānìm samyātukāmena ca bhāvi vācyam \|

ayam arthạ̣ | lagnādhīśạ̣ kāryādhīśo vā viparītabhāve svaśatrunīcādiduștasthāneșu gatah san pāpair yukta îkṣito vābhūt tadā prāg aśubham abhavat | evaṃ sarvatra | saṃyātukāmena rāśyantasthena śīghreṇa pāpagraharāśau saṃyātukāmena kṛtvā bhaviṣyad anișțạ̣ vācyam | bhāva- 10 daśādāv ity arthah || athetthaśāle viṃśopakānayanam |

pṛsțhasthaśīghragrahahīnamandagrahasya bhāgai rahitā vidheyāḥ | pṛ̦țhasthaśīghragrahadīptabhāgāh prșțhasthaśīghradyutibhāgabhaktāḥ | phalam yad āptam nakhasaṃuṇam tad viṃśopakāḥ syur muthaśîlamukhye || iti |

udāharaṇam | mandagraho bhaumo rāśyādiḥ $7 \mid 16$ śīghraḥ sūryo rāśyādị̣ $\left.4\right|_{2} ^{2}$ | atha sūryasyāṃśaiḥ 2 bhaumasyāṃśāḥ 16 hīnāḥ 14 ebhị̣ sūryasya dīptāṃśā 20 15 hīnāḥ śeșe 1 sūryasya dīptāṃśair 15 bhakte labdham o|4 nakhaguṇaṃ jātā itthaśāle viṃśopakāḥ 1|20 ||

1 yutekṣito] yutokṣito $\mathrm{B} N$ || bhavitāthavāste] bhavitā vāthaste $\mathrm{N}$ a.c.; bhavitā vāthavāste $\mathrm{N}$ p.c.; bhavitānyathāste G p.c.; bhavitāpy athāste KT M 3 vyatyastam asmād] vyatyas tasmād KT; vyatyasta tasmād M 6 vācyam] iti add. G p.c. 7 lagnādhīśạ kāryādhīśo] lagnādhīśo M || sva] om.KTM || nīcādi] nīcādiṣu G p.c. 8 san] sat BNG || pāpair] pācair N || ìkṣito] ikṣato B N G a.c.; ikșito G p.c. 9 sarvatra] sabīgha N 10 vācyam] ity arthah add. K T M 11 daśādāv] daśād B N G 13 prșțhastha] prșțhasya B N $\quad 15$ dīpta] dīpti G p.c. 16 stha] sta G 17 nakha] nașa B N 19 16] 1 B N a.c. $\quad 20$ atha] atra K T M 21 dīptāmśair] dīptāṃśā K T

1-6 svarkșādi ... vācyam] ST 2.22-23 
If [one of these planets], occupying a good place such as its domicile, was [previously] joined to or aspected by benefics, will be so, or remains so [at present], then the good [result] was previously complete, or it will be so in future, or it is so [now, respectively]. If the circumstances are contrary, it is the opposite of this, or [if the planet] has gone from a good sign to an evil sign, [the result] was previously good but is now evil; and from a planet about to enter [an evil sign], future [evil] should be predicted.

The meaning is as follows: [if] the ruler of the ascendant or the ruler of the matter sought, in contrary circumstances, [that is], occupying an evil place such as [that of] an enemy or its fall, was [previously] joined to or aspected by malefics, then previously [the result] was evil. The same [principle should be applied] everywhere. From a planet about to enter, [that is], a swifter [planet] placed at the end of a sign and about to enter the sign [occupied by] an evil planet, once it has done [so], future evil should be predicted, [namely], in the period of [that] house and so on: this is meant.

Next, calculating the twenty-point strength in an itthaśāla: ${ }^{14}$

The degrees [of longitude] of the slower planet, less by [the longitude of] the swifter planet placed behind [it], should be subtracted from the orb of light of the swifter planet placed behind and divided by the orb of light of the swifter [planet] placed behind. ${ }^{15}$ The result derived, multiplied by twenty, is the strength in points in a mutthaśila and so on.

An example: the slower planet is Mars, whose [position in] signs and so on is 7,16 ; the swifter one is the sun, whose [position in] signs and so on is 4 , $2 .{ }^{16}$ Now, the 16 degrees of Mars less by the 2 degrees of the sun is 14 . These are subtracted from the orb of light of the sun, 15. When the remainder 1 is divided by the orb of light of the sun, 15, the result is 0;4. Multiplied by twenty it gives 1;20 points of strength for the itthaśăla.

14 As the following verses are neither a continuation from the Samjiñatantra nor otherwise attributed, I assume that they were authored by Balabhadra himself.

15 The repetitions are in the original.

16 The notation means ' 7 signs 16 degrees [completed]' and ' 4 signs 2 degrees [completed]', in other words, positions in Scorpio and Leo, respectively; cf. the Introduction. 
atha șoḍaśayogaprāntye likhitam yādavavṛttenāvadhidinānayanam | tatra bhaumārkayor aṃśāntaram 14 dvādaśaguṇam 168 jātāny avadhidināni | evaṃ sarvatra jñeyam \|

varșalagne saumyagrahetthaśālaphalam uktaṃ tājikasāre |

yadītthaśâlaḥ khacarais tu saumyaị krto 'bdalagne paripūrṇakaś ca | datte tadāsau vividhaṃ vilāsaṃ dhanāgamam kāntivivardhanam ca || iti |

itthaśālādīnāṃ̣ phalaṃ jīrṇatājike |

itthaśālaḥ svayaṃ kartāyamayā naktam anyataḥ|

isarāphah svayam hartā maṇaū cānyahastataḥ|

khallāsaraih phalābhāva iti varșe vicintayet \|

atra lagneśakāryabhāveśayor itthaśālādiyogotpattau etat phalaṃ vācyam iti | itītthaśālaḥ ||

athesarāphayogah | tatresarāphayogalakșaṇaṃ tājikabhūṣaṇe |

śīghragraho mandagater grahāt tu yadaikabhāgaṃ puratah prayāti | sa isarāphah sa tu mūsarīphah purātanair dușțaphalah pradișțậ \|

5 yadītthaśālaḥ] yadītthaśālā B N G \| kṛto] vṛto N 6 ca \| iti] cet B N G 7 phalaṃ] om. B N G a.c. 11 atra ... iti] om. B N G a.c. || lagneśa] scripsi; lagne K T M 15 sa īsarāphah] tadesarāphas K T M

5-6 yadītthaśālah ... ca] TS $93 \quad$ 14-15 śīghra ... pradișțaḥ] TBh 4.10

11 atra ... iti] G, which adds this sentence in a different hand in the margin, does not indicate where it is to be inserted. 
Next, the calculation of days remaining according to the method of Yãdava is written at the end of [the section on] the sixteen configurations [in Täjikayogasudhānidhi 6.35]. ${ }^{17}$ In that [method], the distance of 14 degrees between Mars and the sun, multiplied by twelve, gives 168 days remaining. It should be understood thus in all [cases]. ${ }^{18}$

The result of an itthaśāla of benefic planets in the ascendant of the year is described in Täjikasāra [93]:

If a perfected itthaśāla is formed by benefic planets in the ascendant of the year, it gives manifold pleasures, gain of wealth and an increase in beauty.

The results of itthaśála and other [configurations are described] in the Jirnatājika:

[If there is an] itthaśāla, [the native] himself creates [something; if] a yamaya or nakta, [it comes] from another. [If there is an] isarāpha,

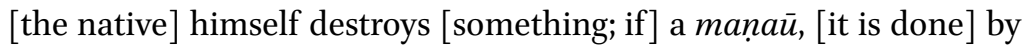
another's hand. By khallāsara, nothing results: thus one should judge [configurations] in [the revolution of] the year.

Concerning this, one should predict these results if the ruler of the ascendant and the ruler of the house of the matter sought form an itthaśa la or other configuration. This concludes the itthaśâla.

\subsection{The İsarāpha Configuration}

Next, the isarāpha configuration; and the definition of an isaräpha configuration [is given] in Tājikabhūṣaṇa [4.10]:

When the swifter planet moves in front of the slower planet by one degree, that is an isarāpha or a müsarihpha, declared by the ancients to give evil results.

17 For some reason Balabhadra here departs from his usual policy of verbatim quotation. For the stanza in question, see the end of section 3.16.

18 This principle of assigning 12 days to each degree of longitude is based on the prognostic technique known as annual profections, which gives rise to the munthahā discussed in Chapter 5 , although Balabhadra nowhere connects the two. See the Introduction. 
atha śīghragrahasya mandagrahaikāṃśātikramaṇe īsarāphayogah | ekāṃśāpūrtyai kalānām atikrameṇetthaśālayoga iti jīrṇațịākṛt | atresarāphayogạ̣ saumyagrahajanitaḥ śubha ity uktaṃ hillāje |

isarāphe saumyajāte kāryabhañgo na jāyate | iti |

atha śīghragraho mandam atikramya dvādaśāmuśābhyadhiko bhavet tadāpi mūsariphah śubhaphalada evety uktaṃ yādavena |

caro 'carāc carel lavam puraḥ sa isarāphakaḥ| śubho na mūsarīphakaḥ śubho 'rkabhāgagas tu cet \|

atrodāharaṇam āha sa eva |

dhanurvilagne gurur aștibhāgo budho 'dricandro mithunam gato 'tra | na kanyakāyà varaläbhasiddhih syāt piṇdatulye 'tra budhe tadāptih \|

athesarāphayoge viṃśopakānayanam |

pṛșțhasthamandagrahahīnaśīghragrahasya bhāgā nakhasaṃuṇāś ca | agrasthaśīghragrahadīptabhāgair bhaktā viśopāḥ syur ihesarāphe ||

iti īsarāphayogah ||

1 grahaikā-] grahasyaikā- K T M $\quad 1-2$-āpūrtyai] -āpūrtau K T M 2 krameṇetthaśāla] kramaṇe pītthaśāla K T M 7 'carāc] carā B N G \| carel] care B N G a.c. K T M \| lavaṃ] om. B NG a.c. 8 cet] te BNG 10 bhāgo] bhāgair KT M \| candro] candrair KT M 11 piṇ̣̣a] paṃ*ạa B; paṃḍa N G a.c. 14 viśopāḥ] viśopakā B N G a.c.

7-8 caro ... cet] TYS $6.12 \quad 10-11$ dhanur ... tadāptiḥ] TYS 6.13

11 piṇa] $\mathrm{B}$ inserts a character of uncertain meaning, similar to $t a$ but without the top stroke, in the middle of the word pamda. 
Thus the isarāpha configuration [is formed] when the swifter planet passes beyond the slower planet by one degree. By [merely] passing beyond its minutes of arc, without completing one degree, [the swifter planet still forms] an itthaśăla configuration: so says the ancient commentator. Concerning this, it is stated in the Hillāja[täjika] that an isarāpha configuration formed by benefic planets is good:

When an isaräpha is produced by benefics, the destruction of the matter sought does not result.

Next, Yādava says [in Tājikayogasudhānidhi 6.12] that [when] the swifter planet, passing beyond the slower one, exceeds it by twelve degrees, then, too, the müsarihpha gives good results:

[When] the swifter moves a degree in front of the slower, that is $\bar{\iota}$ sara $\overline{-}$ pha. A mūsarihpha is not good; but it is good if it attains twelve degrees.

He gives an example of this himself [in Täjikayogasudhānidhi 6.13]:

Jupiter is in a Sagittarius ascendant at sixteen degrees; Mercury is in Gemini at seventeen. Here there is no success in winning a girl in marriage; [but] if Mercury here has twenty-eight [degrees, the querent] obtains her.

Next, calculating the twenty-point strength in an isaräpha: ${ }^{19}$

The degrees [of longitude] of the swifter planet, less by [the longitude of] the slower planet placed behind [it], multiplied by twenty and divided by the orb of light of the swifter [planet] placed ahead, is the strength in points of this isarāpha.

This concludes the isarāpha configuration.

19 Again, this verse was most probably authored by Balabhadra himself. 
atha naktayogah | tatra naktayogalakșaṇaṃ saṃjñātantre |

lagneśakāryādhipayor na drșțir mitho 'tha tanmadhyagato 'tha śĭghrah| àdāya tejo yadi prșțasaṃsthān nyased athānyatra hi naktam etat \|

anyatra mandagrahe pṛșțhasaṃsthāc chīghragrahād ity arthah | atra sarvatra svadīptāṃśamadhye yadi śīghragrahān mandagraho 'dhiko bhavati tadā śīghro mandasya tejodātā mandaḥ śīghrasya tejoharo jñeyaḥ | dīptāṃśamadhye śīghragrahān nyūnāmśe mandagrahe śīghro mandasya tejoharạ mandaḥ śīghrasya tejodātā jñeyah | vakṣyamāṇamaṇaūyoge viśeșavākyāc chīghrād adhikāṃśo nyūnāṃśo 'pi mandạ̣ śīghrasya tejohartā bhavatīti tattvam | atrodāharaṇaṃ saṃjñātantre |

strīlābhaprcchātanur asti kanyā svāmī budhaḥ siṃhagato daśāmśaih | sūryāṃśakair devaguruḥ kalatre dṛștis tayor nāsti mitho 'tha candraḥ $\|$ cāpe vrșe cobhayadrśyamūrtiḥ śighro 'rkabhāgair athavā bhavāmsśaih | àdāya tejo budhato dadau yaj jīvāya lābhah parataḥ striyāh syāt $\|$

1 naktayogah | tatra] om. B 5 dīptāṃśa] dīptāṃśair B N G a.c. $\quad 5^{-7}$ 'dhiko ... grahe] om. B N G a.c. 12 kalatre] kalatram M 13 'rka] 'lpa G p.c. 14 striyāḥ syāt] striyās tat K T

2-3 lagneśa ... etat] ST $2.25 \quad 11-14$ strī ... syāt] ST 2.26-27 


\subsection{The Nakta Configuration}

Next, the nakta configuration; and the definition of a nakta configuration [is given] in Samjiñätantra [2.25]:

If there is no aspect between the ruler of the ascendant and the ruler of the matter sought, but a swifter [planet], placed between them, takes the light from [the planet] placed behind [it] and commits it to the other one, this is nakta.

'To the other one' means 'to the slower planet'; 'from [the planet] placed behind [it]' means 'from the swifter planet'. ${ }^{20}$ Here, in every [case], if the slower planet exceeds the swifter planet [in longitude] within their own orbs of light, then the swifter one is understood to give its light to the slower one, and the slower one, to take the light from the swifter one. If, within the orbs of light, the slower planet has fewer degrees [of longitude] than the swifter planet, the swifter one is understood to take the light of the slower one, and the slower one, to give [its] light to the swifter one. [But] by a special rule, in the manaū configuration described below, the slower one, whether it has more or fewer degrees [of longitude] than the swifter one, takes the light from the swifter one: this is the truth of the matter. Concerning this [nakta configuration], there is an example in Samjñätantra [2.26-27]:

In a question about obtaining a wife, Virgo is the ascendant; [its] ruler Mercury is in Leo with ten degrees; Jupiter is in the seventh house [Pisces] with twelve degrees. There is no aspect between them; but if the moon in Sagittarius [or] Taurus with twelve or eleven degrees, aspected by both and swifter [than both], taking the light from Mercury, gave it to Jupiter, [the querent] would obtain a wife through [the help of] another.

20 This interpretation is neither astronomically necessary nor, to my knowledge, supported by Arabic-language sources. The example cited shortly below has the moon at $11^{\circ}$ separating from an aspect to Mercury at $10^{\circ}$ and applying to one with Jupiter at $12^{\circ}$; but if Mercury and Jupiter reversed their longitudes so that the moon separated from the latter and applied to the former, the scenario would still constitute a translation (naql) of light, that is, nakta-yoga. Balabhadra in his explication does in fact go on to confirm that either planet may give or receive light, thereby contradicting his own overly restrictive gloss. 


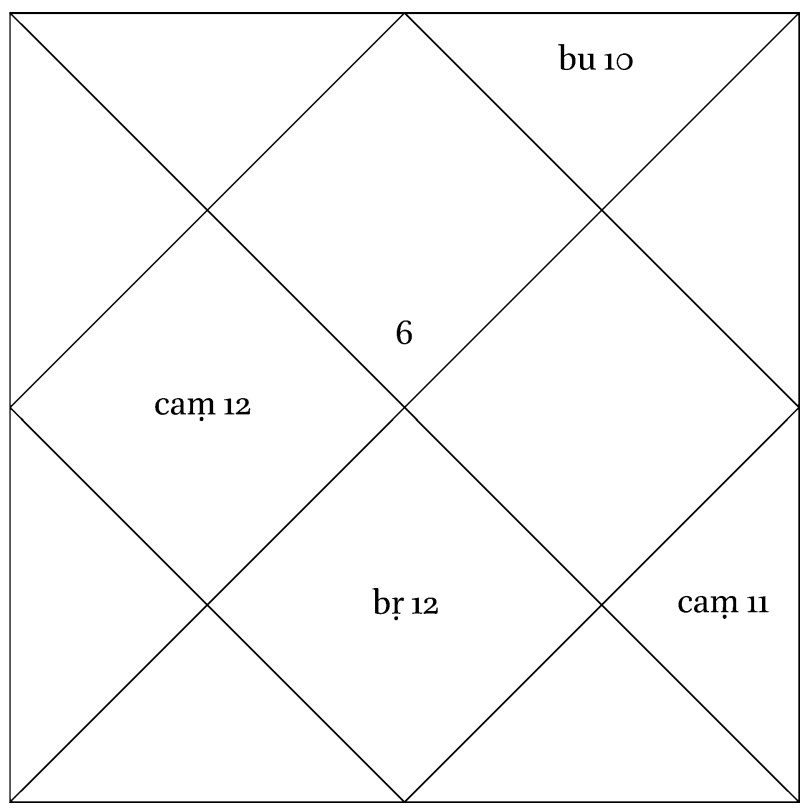

naktayogah

ayam arthaḥ | atra lagneśakāryeśayoḥ parasparaṃ șaḍașțagatvāt dṛștị nāsti | atha śīghraś candro 'nyonyaṃ budhaṃ gurum ca paśyan svasmād alpāṃśād budhāt tejo gṛhītvā svasmād adhikāṃśāya gurave dadau | tasmāt parahastāt strīlābhah \||

atra sthānadṛștisadbhāve 'pi dīptāṃśātikrameṇa naktayogo bhavatīty uktaṃ yādavena |

lagneśakāryapakhagau nijabhāgadṛ̦țāa

hìnāv ubhau carakhago 'ntaragah prapaśyan |

nìtvā mahaś caragater acalāya dadyān

naktam bhaved aparahastavilambasiddhyai $\|$

atrodāharaṇam āha sa eva |

2 paśyan] san add. G p.c. $\quad 7$ dṛsțyā] dṛsțvā B N G a.c. 8 khago] șago N $\|$ prapaśyan] pravaśyan G 9 caragater acalāya] caragateḥ khacarāya B N G

7-10 lagneśa ... siddhyai] TYS 6.14

21 That is, when planets occupy either the same sign or signs that form an aspect angle $\left(60^{\circ}, 90^{\circ}, 120^{\circ}\right.$ or $\left.180^{\circ}\right)$, without consideration of the exact position of the planets within those signs. 


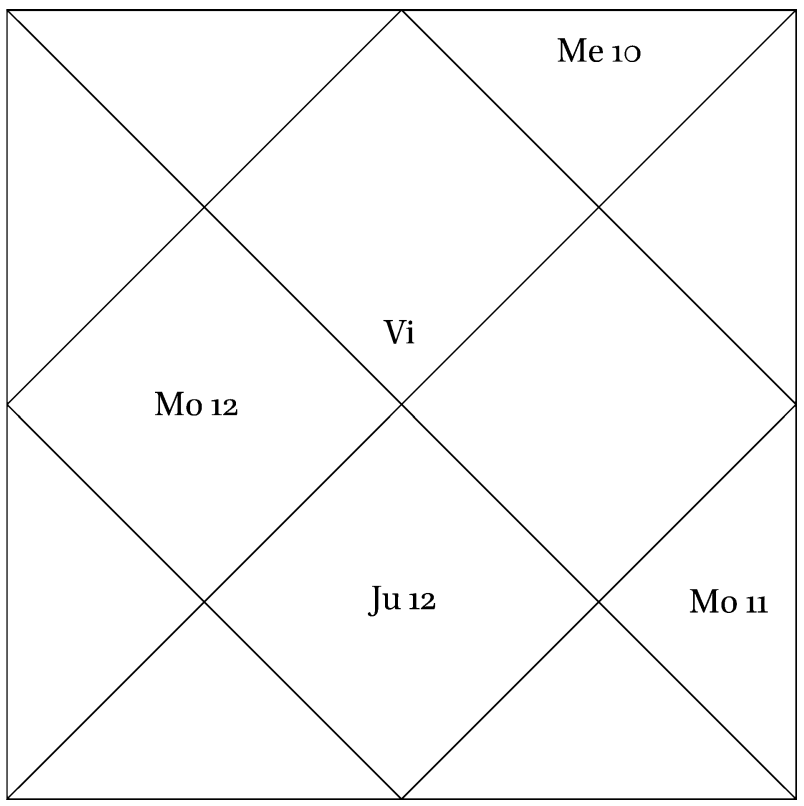

The nakta configuration

The meaning is as follows: here, because they are placed in the sixth and eighth [sign] from each other, [respectively], there is no aspect between the ruler of the ascendant and the ruler of the matter sought. But the swifter moon, mutually aspecting both Mercury and Jupiter, took the light from Mercury, which had fewer degrees [of longitude] than [the moon] itself, and gave it to Jupiter, which had more degrees than [the moon] itself. Therefore, [the querent] obtains a wife by another's hand.

Concerning this, Yādava says [in Täjikayogasudhānidhi 6.14] that even when an aspect by place is present, ${ }^{21}$ a nakta configuration arises when the orb of light is exceeded:

[If] the planets ruling the ascendant and the matter sought are without an aspect within their own orbs [of light, but] a swifter planet placed between them, aspecting them both, takes the light from the swifter one and gives it to the slower one, [this] is a nakta, leading to success by the helping hand of another.

He himself gives an example of this [in Tājikayogasudhānidhi 6.15]: 
mine vilagne gurur arkabhāgaḥ striyām budho netralavo na dṛștị | tayoś ca madhye 'drilava h kulìre candras tadānyena sakhe 'ñganāptị̣ || iti |

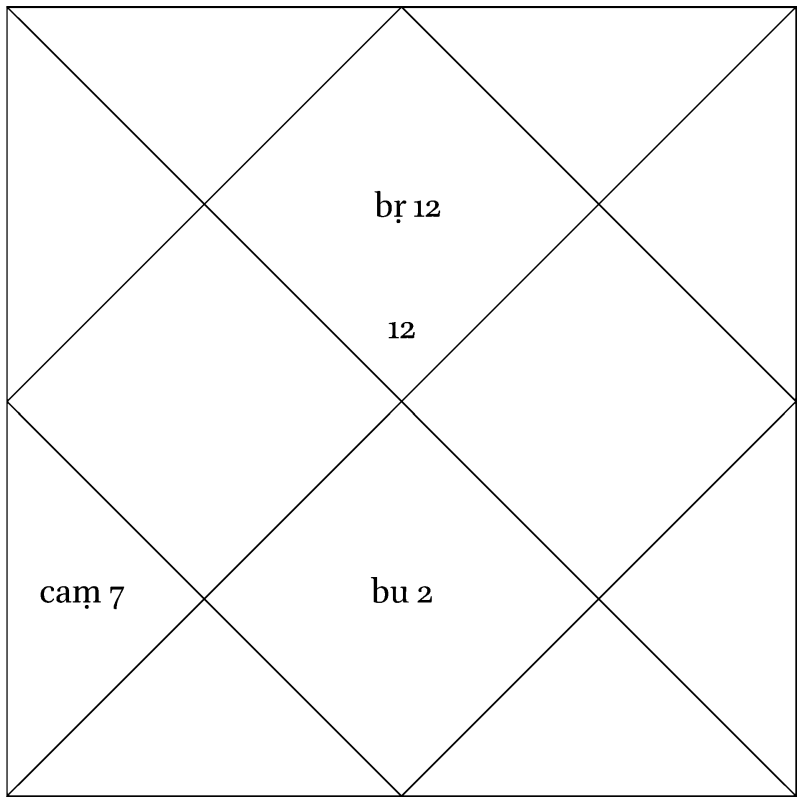

punar naktayogah

iti naktayogah \|

atha yamayāyogaḥ | tatra yamayāyogalakṣaṇam uktam tājikabhūṣaṇe |

parasparālokanavarjitam yat khețadvayam paśyati mandakhețạ | dīptāṃśakair dhāma carād gṛhītvā sthirāya datte yamayābhidhānah ||

2 tadānyena] tadānyeta B N G || iti] eva B N G

1-2 mīne ... 'ṅganāptị̣] TYS 6.15 $\quad$ 5-6 parasparā- ... -dhānaḥ] TBh 4.13

22 The notion that the slowest-moving planet in the jāmi'a/yamayā configuration should occupy an intermediate degree with regard to the other two planets involved (within their respective zodiacal signs) probably arose from analogy with the fastest-moving 
Jupiter is in a Pisces ascendant at twelve degrees; Mercury is in Virgo at two degrees: there is no aspect. But if the moon is between them at seven degrees in Cancer, then, friend, [the querent] obtains a wife through another [person].

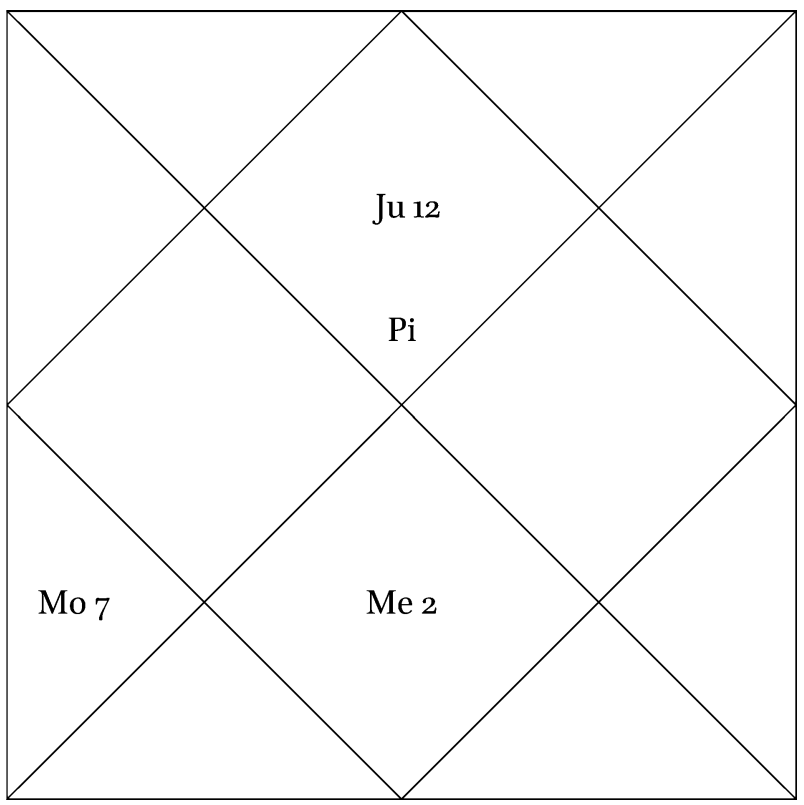

Another nakta configuration

This concludes the nakta configuration.

\subsection{The Yamayā Configuration}

Next, the yamaya $\bar{a}$ configuration; and the definition of a yamayā configuration is stated in Täjikabhüṣaṇa [4.13]:

If a slower planet within its orb of light aspects a pair of planets lacking a mutual aspect and, taking the light from the swifter, gives it to the slower, [that is] called yamay $\bar{a}^{22}$

planet in the naql/nakta configuration. In the jämi'a as defined by Sahl ibn Bishr, both the faster-moving planets must in fact occupy earlier degrees in order to form applying (approaching) aspects with the third and slowest planet, which then collects their light. 
ayam arthạ̣ | parasparālokanavarjitaṃ khețadvayaṃ lagneśakāryeśābhidham | tṛtīyo 'nyo mandagrahạ̣ svadīptāṃśair lagnādhīśakāryādhīśau sthānadṛsṭtyā paśyet | punar ubhayor madhye śīghrāt tejo nītvā mandagāya datte tadā yamayāyogaḥ syāt | atrodāharaṇaṃ saṃjñātantre |

räjyāptipṛcchātulalagnanātho meșe sitas tv așțilavair vrṣasthaḥ|

candro rasāmśair yadi rājyanātho dṛștis tayor nāsti gurus tu mandaḥ $\|$ digamiśakah karkagatas tu paśyann ubhau maho dīptalavaị sa cāndram | dadau sitāyeti padasya lābho 'mātyena bhāvîti vimrśsya vācyam \|

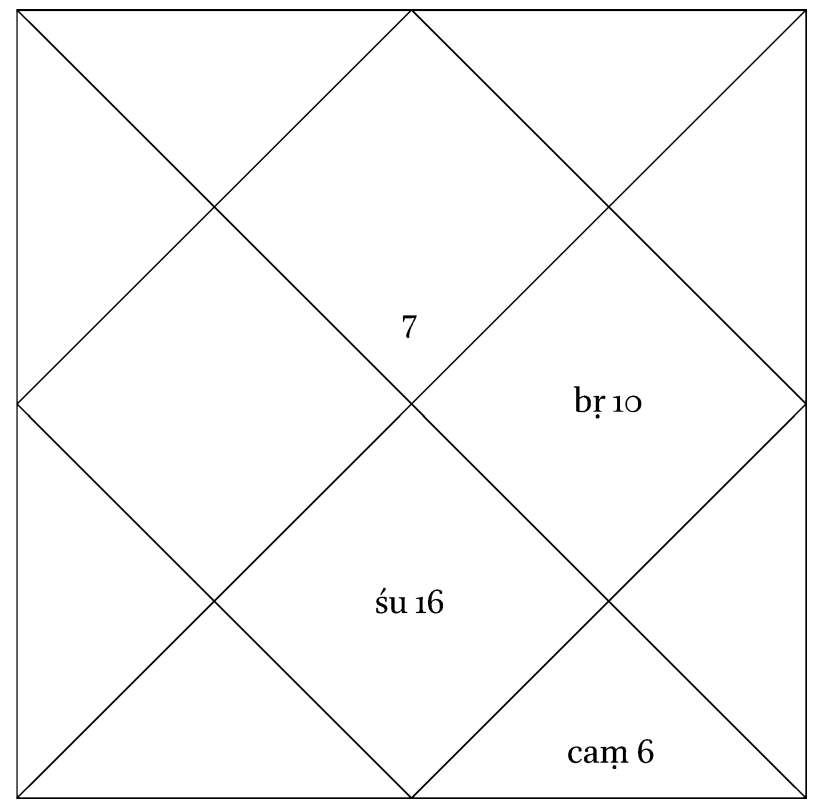

yamayāyogah

2 'nyo] om. KT || manda] śīghra G p.c. 3 paśyet] paśyan K T M || śīghrāt] śīghrat K; śīghra M 3-4 mandagāya datte tadā] maṃdagātadaya T 4 tadā] om. K M \|| yamayā] yamayo B; yamayākhyo K T M 6 nātho] nātha B N G a.c. 7 digaṃśakaḥ] digaṃśataḥ M $\|$ karka] karke T 8 'mātyena] 'mātyeta G

5-8 rājyāpti ... vācyam] ST 2.29-30 
The meaning is as follows: a pair of planets, namely, the ruler of the ascendant and the ruler of the matter sought, lack a mutual aspect. Another, third, slower planet aspects the ruler of the ascendant and the ruler of the matter sought with an aspect by place [and] within its own orb of light. Further, of the two, it brings the light from the swifter and gives it to the slower: then there is a yamaya configuration. An example of this [is given] in Samjñ $\bar{a}-$ tantra $[2.29-3 \mathrm{O}]$ :

If Venus, ruler of Libra ascendant in a question on achieving dominion, is in Aries with sixteen degrees, and the moon, ruler of [the tenth house of] dominion, is placed in Taurus with six degrees, there is no aspect between them; but [if] the slower Jupiter, placed in Cancer with ten degrees and aspecting both, gave the light of the moon within its orb of light to Venus, one should consider and predict that [the querent] will attain the rank through a counsellor.

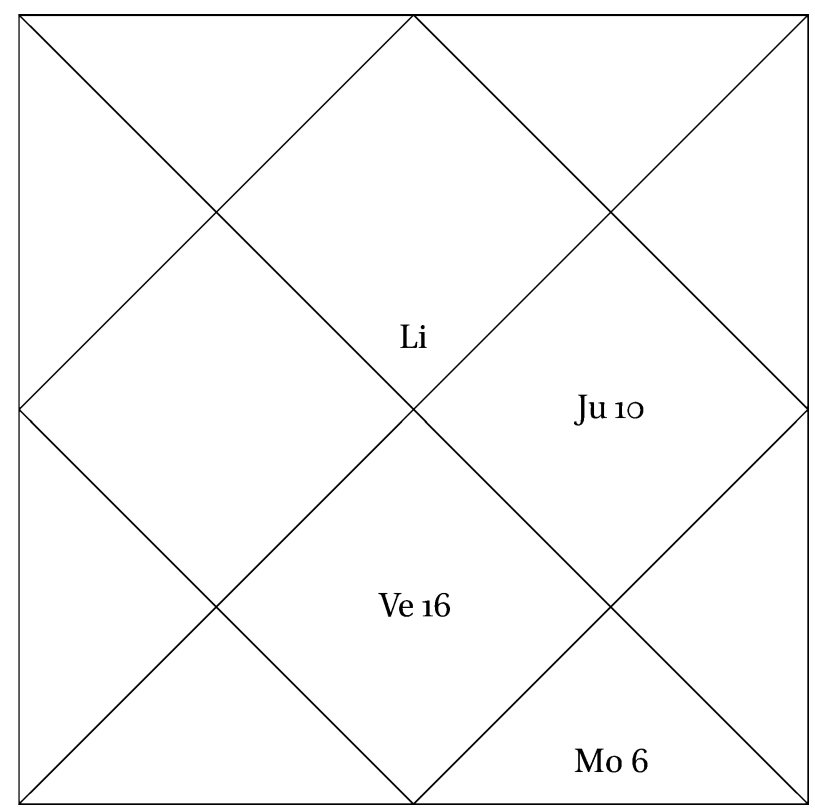

The yamayā configuration 
atra lagneśakāryeśayor dvirdvādaśakatvād anyonyam dṛșțir nāsti | tṛtīyo gurur mandagāmī karkastho daśāṃśah lagnādhīśakāryādhīśau sthānadụșțāā paśyan svalpāṃśād dhimāṃśọ svadīptabhāgais tejo g̣̣hītvā bahvaṃśāya śukrāya dadau | tasmān mantridvārayā rājyalābho vācyaḥ | iti yamayāyogah ||

atha maṇaūyogaḥ | tatra maṇaūyogalakṣaṇam āha yādavaḥ |

bhaumo vā ravijaś carasya puratah prșțhe 'thavā samsthitaḥ paśyan śatrudrśā svadīptalavakair hīnair ahīnair api | yatkāryārtham atho kṛtạ̣ muthaśilaṃ tatra sthito vā graho gṛnnàtīha maho maṇur nigadito yogo 'rthanāse pațuh $\|$

manuṣyajātake samarasiṃho 'pi |

jāte 'piyoge ravijo 'tha bhaumah

śighrasya prșțhe 'tha puro 'ridrștya $\mid$

svāmeśair mahas tv ekagatas tu hìnā-

dhikaiś ca sa syān maṇaū na śastaḥ || iti |

1 dvir] dvi B N G || anyonyaṃ] anyonya K T M 3 paśyan] san add. K T M || dhimāṃśoḥ] dhimāṃśaị B N G || bahvaṃśāya] vahvaṃśā B N G a.c. 4 dadau] dadaus G \| mantri] maṃtra K T M \| rājyalābho] mātyena add. K T M $\quad 5$ yoga] om. B N G a.c. 9 maṇur] maṇaūr B N G || nāśe] nāśo B a.c. N G 10 jātake] tājike K T M 13 mahas] grahas T 14 sa] sah B N G K T

6-9 bhaumo ... pațuh] TYS $6.19 \quad$ 11-14 jāte ... śastaḥ] KP 3.8

4 mantri ... rājyalābho] K T M obviously add [']mātyena as a result of misreading the homosemous mantridvārayā. 9 gṛhṇātīha] B inserts a character of uncertain meaning, similar to $y a$ but without the top stroke, in the middle of this word block. $\quad 11$ jāte] B inserts a character of uncertain meaning, similar to $p a$ but without the top stroke, in the middle of this word.

23 Jupiter, among other things, signifies ministers or counsellors. Text witnesses K T M misread 'by means of the counsellor' as 'by means of mantras' and add: 'through the counsellor'. 
Here, because the ruler of the ascendant and the ruler of the matter sought are in the second and twelfth from each other, [respectively], there is no aspect. The third [planet], Jupiter, moving more slowly and placed in Cancer with ten degrees, aspecting the ruler of the ascendant and the ruler of the matter sought with an aspect by place and taking the light from the moon, which had fewer degrees [of longitude], within its own orb of light, gave it to Venus, which had more degrees. Therefore, the attainment of dominion by means of the counsellor should be predicted. ${ }^{23}$ This concludes the yamaya configuration.

\subsection{The Mañaū Configuration}

Next, the manaū configuration; and Yādava states the definition of a maṇaū configuration [in Täjikayogasudhānidhi 6.19]:

[If] Mars or Saturn, placed ahead of or behind the swifter planet and aspecting [it] with an inimical aspect within its own orb of light, whether less or greater [in longitude]; or else, [if] the [malefic] planet occupies [the house] of the matter for which the mutthaśila is formed and here takes the light, [that] configuration is called manaū, powerful in destroying the matter.

And Samarasiṃha in Manușyajātaka [3.8]:24

Even if an [itthaśāla] configuration is formed, [if] Saturn or Mars, behind or ahead of the swifter [planet], by an inimical aspect within its own degrees, whether less or greater, [takes] ${ }^{25}$ the light, or occupies a single [sign with the swifter planet], ${ }^{26}$ that is manaū, [which is] not good.

24 Among the many quotations from Samarasimpha given by Balabhadra, this is the only one attributed to the Manusyajätaka (the original title of which appears to be Karmaprakāśa); see the Introduction and Gansten 2019. The metre is not the moraic $\bar{a} r y \bar{a}$ typical of other quotations from Samarasimnha, but the syllabic upajāti.

25 The verb is missing in all versions of the stanza available to me and must be supplied from previous verses.

26 This tentative translation of the terse phrase ekagatah 'occupying one' follows the commentary by Nārāyanabhaț̣a Sāmudrika, who explains: 'The one-sign aspect should be understood to have been mentioned separately because, in the opinion of some, it is a friendly aspect.' 
pūrvapadyasyāyam arthạ̣ | bhaumaḥ śanir vā lagneśakāryeśayor madhye śīghragrahasyāgre pṛșțhe vā sthitvā caturthasaptamaikarāśidṛsțyā paśyan san svadīptāmsśair hīnair adhikair vā śīghrasya tejo gṛhṇāti | tatra lagneśakāryeśayor itthaśāle 'pi kārye nāśako maṇaūyogaḥ | athavā yat kāryanimittam lagneśakāryeśābhyāṃ yasmin sthāne muthaśilaṃ kṛtạ̣ tatra dvayor ekasthānago bhaumaḥ śanir vā hīnair adhikair vā svadīptabhāgair dvayor ekasya vā tejo g̣̣hṇāti sa maṇaūyogaḥ | kāryanāśako jñeyaḥ | atra śrīharibhațtadaivajñakṛtaḥ saṃgrahaślokah |

\section{bhaumah śanir vāyadi mūthaśîlisarāphavān śïghraripugrahena |} lagneśakāryādhipatītthaśálaphalapraṇāsí maṇaū śubho na \|

atrodāharaṇam āha yādavaḥ |

kanyāvilagne 'sti budho 'stanātho daśāṃśakair āngiraso 'dricandraị | mine ca yugme 'vanijo bhavāmśair mușto budhas tena na cānganāptịh \| prșțe 'pi bhaume navabhis tathaiva mine kavir hastimito 'tra püjyah | nrpaiś ca tatrārkasuto navāṃśair nagaiś ca prșțhe na hi kāryasiddhị \| karke vilagne 'sti kavir dināmśair vrșe 'bhracandrair himaguh kujo 'tra| bhüpair lavair bhümisutena candro hatas tato nātra sakhe 'rthalābhaḥ || iti |

1 padyasyāyam] padyasvāyam B N 4 kārye] kārya K M; kāryya T || yogah] syāt G p.c. 4-6 -yogaḥ ... śa-] om. N G a.c. 6 sthānago] sthānagā B; sthānagau K T 7 g̣̣hṇāti] ṛhāti N \| sa] so B N G K T; vā add. G p.c. T 7-10 atra ... na] om. B N G a.c. 9 yadi] om. K M 12 āngiraso] aṃgirasā K T M 13 bhavāṃśair muṣtọ] bhavāṃśaih prṣṭho B N G a.c. T M; bhavāṃśaiḥ pṛsțau K 15 nagaiś] nāgaiś B N G

12-17 kanyā ... lābhaḥ] TYS 6.20-22

13 mușțo] This reading, added by a different hand in the margin of G, is required by the context and supported by MS TYS 1 .

27 Presumably in a version of the Tãjikasāra available to Balabhadra. Although I have been unable to find this stanza in available independent witnesses of the Täjikasāra, it conforms to the style and metre of the section in that text dealing with the yogas (88-93).

28 Although this interpretation is required to make sense of the text and confirmed by the accompanying figures, what the verse actually says in the form attested by all witnesses is: 'Mercury is in Virgo ascendant, ruler of the seventh, with ten degrees; Jupiter in Pisces with seventeen ....' When Virgo is the ascendant, Mercury rules the ascendant and Jupiter with equal necessity rules the seventh house. 
The meaning of the former verse is this: Mars or Saturn, placed ahead of or behind the swifter planet out of the ruler of the ascendant and the ruler of the matter sought, and aspecting it with a fourth-, seventh- or one-sign aspect within its own orb of light, whether [its degrees are] less or greater, takes the light of the swifter [planet]. In such a case, even if the ruler of the ascendant and the ruler of the matter sought are to form an itthaśäla configuration, the manaū configuration destroys it. Or else, Mars or Saturn, occupying either the place in which or the place for the sake of whose matter a mutthasila is formed by the ruler of the ascendant and the ruler of the matter sought, takes the light of both or one by the lesser or greater degrees of its orb of light. This is summarized in a stanza composed by Śrī Haribhatța Daivajña: ${ }^{27}$

If Mars or Saturn has a mutthaśila or isarāpha with a swifter, enemy planet, [that is] manau , not good, which destroys the result of an itthaśăla between the ruler of the ascendant and the ruler of the matter sought.

Yādava gives an example of this [in Tājikayogasudhānidhi 6.20-22]:

Mercury is in Virgo ascendant with ten degrees; Jupiter, ruler of the seventh, in Pisces with seventeen; and Mars in Gemini with eleven degrees. ${ }^{28}$ Mercury is robbed [of light]; therefore [the querent] does not obtain a wife.

If Mars is behind [Mercury] with nine [degrees], it is the same. [If] Venus is in Pisces at eight [degrees], Jupiter there [too] with sixteen [degrees], and Saturn there with nine degrees or behind [Venus] with seven, there is no success in the matter. ${ }^{29}$

[If] Venus is in Cancer ascendant with fifteen degrees, the moon in Taurus with ten, and Mars there [too] with sixteen degrees, the moon is afflicted by Mars; therefore, friend, [the querent] gains no wealth here.

29 What the matter sought would be in this hypothetical case is not stated, but presumably either Venus or Jupiter is meant to rule the ascendant. The accompanying figures have Pisces rising (making Venus rule the third sign from the ascendant, so that the matter could be related to siblings) with Saturn in Sagittarius. 


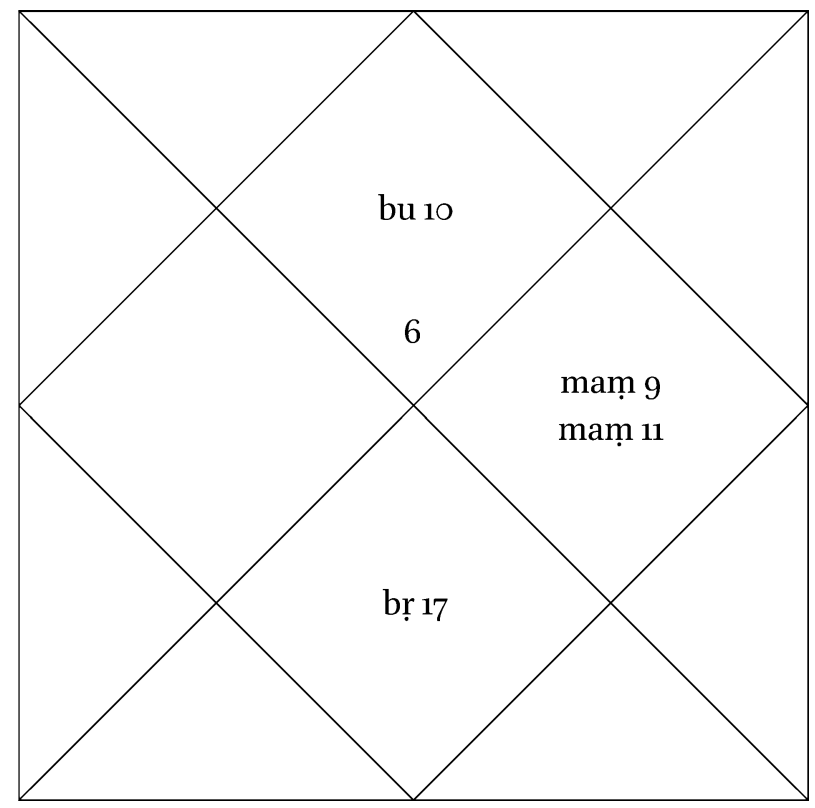

maṇaūyogạ̣

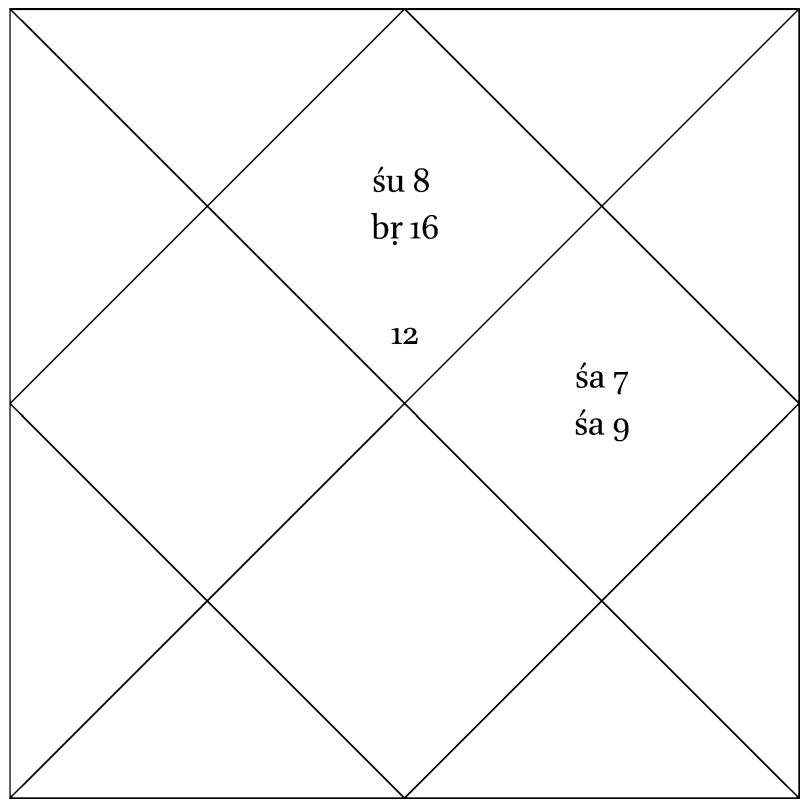

maṇaūyogạ̣ 


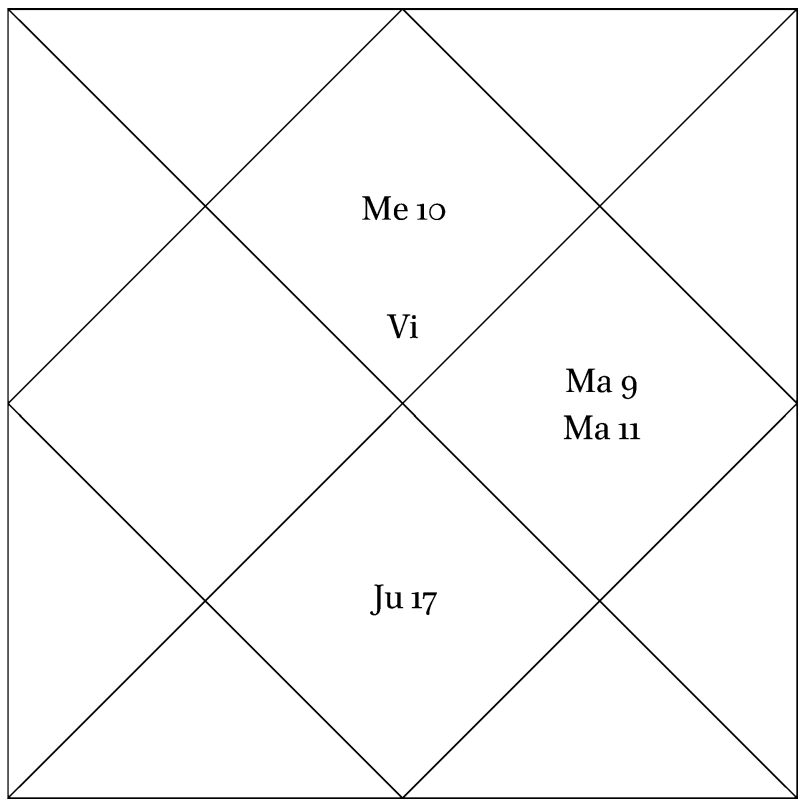

The manaū configuration

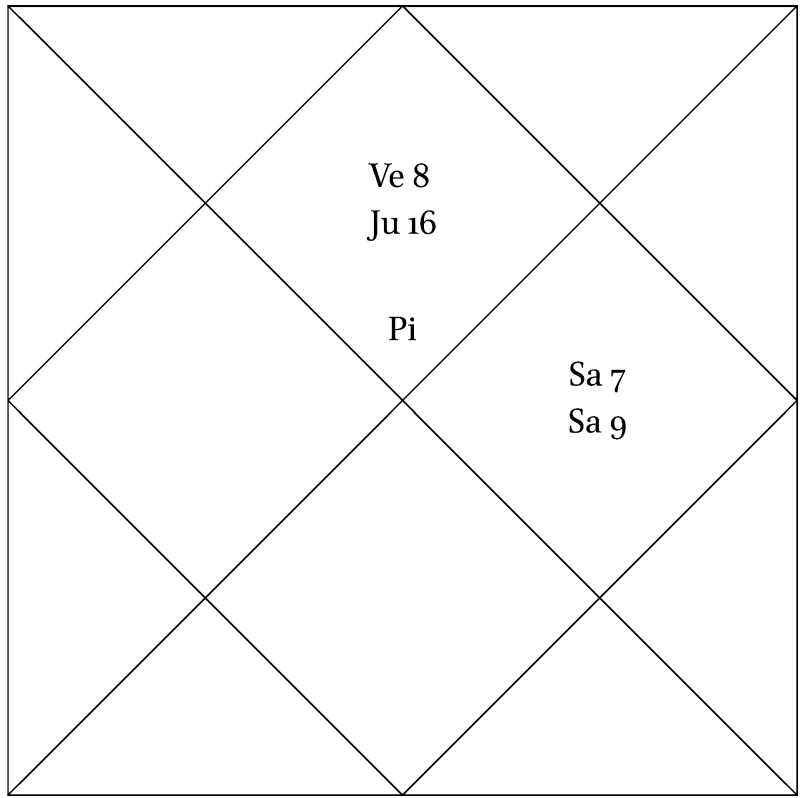

The manaū configuration 


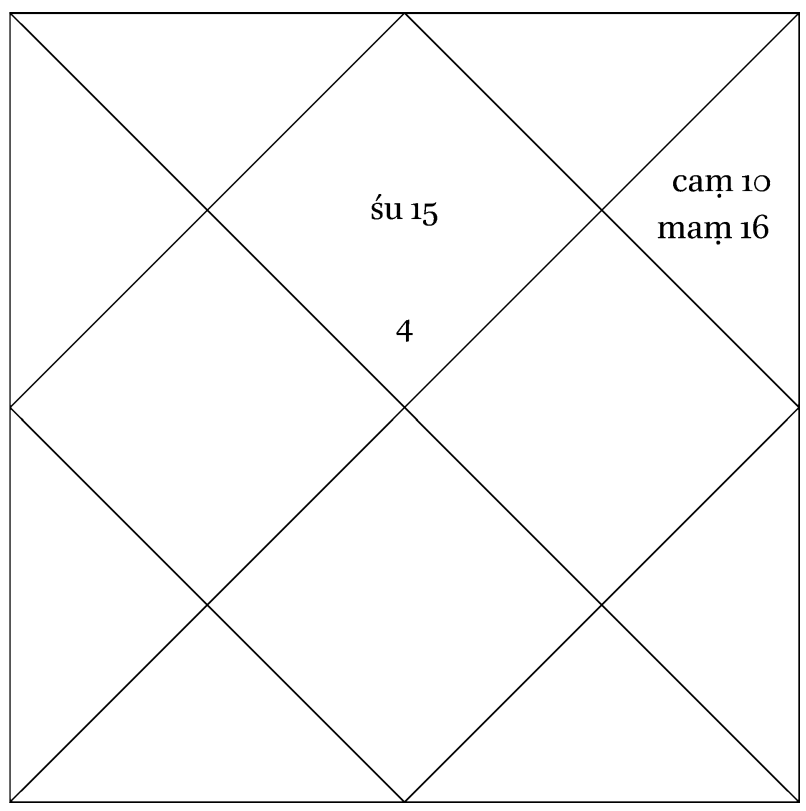

maṇaūyogah

atra prathamodāharaṇe daśamastho bhaumo lagnagam budham turyadṛștyā paśyan san budhād alpāṃśād ekenāṃśenādhiko bhūtvā budhatejoharo jātah | atra strīlābhapraśne kāryeśalagneśayor gurubudhayor itthaśāle 'pi budhasya tejohīnatvāt strīlābho na ca vaktavyaḥ | atha

harate tejah svāmśair hīnādhikaiś ca manaūyogo 'sau|

2 san] om. K T M \| tejo] teja B N G 5 hīnādhikaiś] scripsi; hīnair adhikaiś B N G; ahīnair adhikaiś K T M \| yogo] yoge B N G

5 hīnādhikaiś] The emendation, required by the metre, is made the more plausible by the occurrence of an identical compound in the foregoing quotation from Samarasiṃha (KP 3.8). The reading hinair adhikaiś may have originated as a scribal correction for *hināradhikaiś, with $r a$ representing a misreading of the avagraha (apostrophe): "hinā'dhikaiś. 


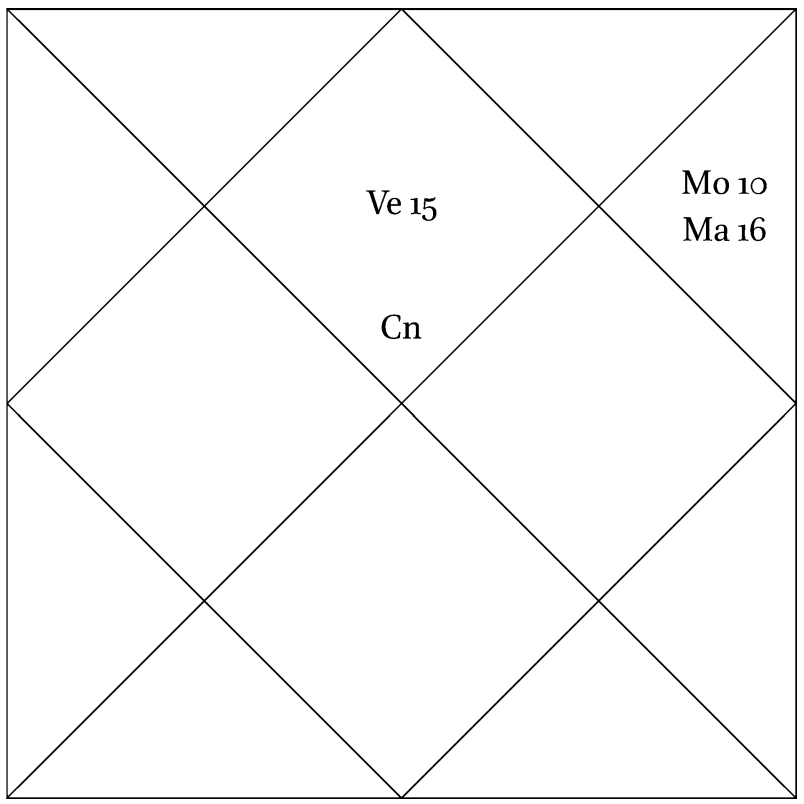

The manaū configuration

In the first example here, Mars being placed in the tenth house and aspecting Mercury in the first house by a fourth-[sign] aspect, exceeding Mercury, who has fewer degrees [than Jupiter], by one degree, takes away the light of Mercury. Here, in a question on obtaining a wife, although there is an itthaśâla between Jupiter and Mercury, the ruler of the matter sought and the ruler of the ascendant, [respectively], because Mercury is bereft of light, obtaining a wife cannot be predicted.

Now, according to the special rule stated by Samarasiṃha [in the Tãjikaśāstra]:30

It takes away the light by its own degrees whether lesser or greater: this is the manaū configuration.

30 This second quotation from Samarasimpha on the manau (cf. note 24) lacks the name of the text quoted, presumably because it was the chief work associated with Samarasimhha. The metre is once more $\bar{a} r y \bar{a}$. Although only the latter half-stanza is quoted here, there are definite similarities between the two verses, suggesting that one was modelled on the other. 
iti viśeșasamarasiṃhavākyena śīghragrahād budhād alpāmśo mandagraho bhaumo navāṃśamito 'pi budhatejoharo jātạ̣ | tasmān navāṃśamite bhaume maṇaūyogatvāt strīlābho na vācyaḥ | evaṃ dvitīyodāharaṇe śukraśanyor yogo jñeyah \||

atha tṛtiyodāharaṇe lābhapraśne karkalagne tadīśaś candro vṛṣe daśāṃśah | tatraiva kujah ṣoḍaśāmśah | atra mando bhaumah śīghrāc candrād adhikāṃśas tasmāc candratejoharo jātah | atra yady api lagneśakāryeśayor itthaśālayogo 'sti tathāpi bhaumakṛtamaṇaūyogatvāl lābho na vācyaḥ | evam ekarāšisthāne 'py udāharaṇaṃ jñeyam | iti maṇaūyogạ̣ ||

atha kambūlayogaḥ | tatrānekabhedasahitakambūlayoga uktah saṃjñā- 10 tantre |

lagnakāryeśayor itthaśāle 'trendvitthaśālatah | kambūlaṃ śreșțhamadhyādibhedair nānāvidham smṛtam \|

atra lagneśakāryeśayor itthaśāle sati ced atra lagneśena kāryeśena cobhābhyāṃ vā candro muthaśilaṃ karoti tat kambūlam | atra kambūlayoge 15 bhedopapattau svagṛhoccāvasthitir uttamo 'dhikāraḥ | svahaddādreșkānanavāṃsáavasthitir madhyamo 'dhikāraḥ | śatrunīcagṛhāvasthitir adhamo 'dhikāraḥ | etattritayādhikārarāhityaṃ samo 'dhikāraḥ | yad āha yādavaḥ |

1 samarasiṃha] samarasiṃhena $B$; samarasiṃhenvaṃna $\mathrm{N}$; samarasiṃhenana $\mathrm{G} \quad 2$ tejo] teja B N G || mite] ti add. B G $\quad 3$ evam]] om. K T M $\quad 5$ lagne] lagnaṃ K T M $\quad 5^{-6}$ daśāṃśaḥ] daśāṃśās M 6 tatraiva] sāstava K; tatra M || candrād] caṃdrārkaud B N G 7 tasmāc candra] tasmāś candra B N G || tejo] teja B N G 9 sthāne 'py] sthānerapy B G K T; sthānerașy N 10 sahita] sahite B N G 12 lagna] lagne G $\quad 13$ śreșța] ceșța M 15 karoti] karotīti T 16 bhedopapattau] bhedoyattau B N G a.c. \| haddā] sva add. G p.c. \| dreṣkāṇa] sva add. G p.c.

12-13 lagna ... smṛtam] ST 2.36

9 sthāne 'py] The ra in B N G K T again most likely represents a misreading of the avagraha. 
- the slower planet Mars, even if it has nine degrees [and thus] fewer degrees than the swifter planet Mercury, takes away the light of Mercury. Therefore, [even] if Mars has nine degrees, obtaining a wife cannot be predicted, because of the manaū configuration. The configuration between Venus and Saturn in the second example should be understood in the same way.

Now, in the third example, in a question on [monetary] gain in Cancer ascendant, its ruler, the moon, is in Taurus with ten degrees; Mars is in the same place with sixteen degrees. Here, the slower Mars has more degrees than the swifter moon; therefore, it takes away the light of the moon. Although an itthaśäla configuration is present here between the ruler of the ascendant and the ruler of the matter sought, still, because of the manaū configuration formed by Mars, gain cannot be predicted. The example should be understood in the same way when [all the planets] occupy a single sign. This concludes the manaū configuration.

\subsection{The Kambüla Configuration}

Next, the kambüla configuration; and the kambüla configuration with its many subdivisions is described in Samjñātantra [2.36]:

When there is an itthaśāla between the rulers of the ascendant and the matter sought, a kambüla, of various kinds according to the divisions into superior, middling, and so forth, is said [to arise] from an itthaśăla [of the two planets] here with the moon.

Here, when an itthaśäla between the ruler of the ascendant and the ruler of the matter sought is present, if the moon here makes a mutthasila with the ruler of the ascendant, the ruler of the matter sought, or both, that is a kambüla. Among the subdivisions of this kambüla configuration, the superior class is [a planet] occupying its own domicile or exaltation; the middling class is [a planet] occupying its own haddā, decan, or ninth-part; the inferior class is [a planet] occupying the domicile of an enemy or its fall. The absence of this threefold classification constitutes the neutral class. As Yãdava says [in Tājikayogasudhānidhi 6.23]: 
svoccasvālayaśālinor yadi śaśí svocce svagehe sthitaḥ suśreșțam nijatungageharahito yoge tadā śreșțhakam | svatrairāsikahaddabhāgagatayor madhyam vinaibhis tato hinam hīnatarạ̣ ca nīcaripubhe yogam karotīha cet \|

hīnaṃ samaṃ hīnataram adhamam | evaṃ candrasya lagneśakāryeśayoś cādhikāragaveșaṇayā kambūlam uttamottamādiṣoḍaśabhedabhinnaṃ bhavatīti jñeyam ||

athottamottamakambūlalakṣaṇaṃ saṃjñātantre |

yadīnduḥ svagrhoccasthas tādṛ́au lagnakāryapau |

itthaśālīkabülam tad uttamottamam ucyate \|

atrodāharaṇaṃ tatraiva |

meșe raviḥ kujo vāpi karkarāśigataḥ śaśí|

tatretthaśālāt kambūlam uttamottamakāryakrt || iti |

atra saṃtānapraśne meșalagnaṃ lagneśo bhaumah svagṛhe meșalagne vimśatyamśạ | pañcamabhāvādhīśo raviḥ svocce meșe saptamadaśāṃśạ | candrah karke svagṛhe caturdaśāmśsạ | atrārkabhaumayoḥ kāryeśalagneśayor itthaśālayogo 'sti | candro 'pi dvābhyāṃ sahetthaśālaṃ karoti | tena uttamottamakambūlaṃ jātam | uttamottamakāryam karoti saṃtānaprāptyākhyaṃ kāryam avaśyaṃ karotīty arthạ̣ ||

2 su] sva B N G 5 hīnataram adhamam] scripsi; hīnataramadhyamaṃ B N G K; hīnataram madhyamam TM 6 gaveșaṇayā] gaveșaṇāya B; gaveșaṇāyā NG 8 athottamottama scripsi; athottama B NGKTM \| kambūla] kambū K 9 tādṛśau] tādṛ́ā BNG || kāryapau] kāryapā B N G 10 itthaśālī] itthaśálīka M \|| kabūlaṃ tad ut-] kaṃbūlaṃ tadot- B; kaṃbūlaṃ tad ut- N a.c. G; kambūlam ut- K M; kambūla tad ut- T $\quad 14$ svag̣̣he] svag̣̣ho G $\quad 16$ caturdaśāṃśạ̣] caturdaśeṃśi B 19 prāptyākhyaṃ] praśnākhyaṃ B N G a.c. \| avaśyaṃ] avaśyakaṃ B N G

1-4 svocca ... cet] TYS 6.23 9-10 yadīnduh ... ucyate] ST 2.37 12-13 meșe ... kāryakṛt] ST 2.48 
If the moon, placed in its own exaltation or domicile, is configured with two [planets] in their own exaltations or domiciles, it produces a most superior configuration; if [the moon] lacks [the position in] its own exaltation or domicile, then a superior one; [if it is configured] with two [planets] placed in their own triplicities, haddās, or [ninth]-parts, a middling one; without these [dignities], one lower than that; and in its fall or the sign of an enemy, an even lower one.

'Lower' [means] neutral; 'even lower' [means] inferior. ${ }^{31}$ By such an examination of the dignities of the moon as well as of the ruler of the ascendant and the ruler of the matter sought, the division of the kambüla into sixteen categories should be understood to arise, beginning with the superior/superior.

Next, the definition of a superior/superior kambūla [is stated] in Samjñätantra [2.37]:

If the moon occupies its own domicile or exaltation, and the rulers of the ascendant and the matter sought do the same, the kambüla [arising from that] itthaśála is called superior among the superior.

An example of this [is given] in the same place [Samjñätantra 2.48]:

[If] the sun and Mars are in Aries and the moon in the sign of Cancer, the kambüla [produced] by that itthaśâla is superior among the superior in accomplishing the matter sought.

Here, in a question on children, the ascendant is Aries. Mars, ruler of the ascendant, is in its domicile in Aries ascendant at twenty degrees. The sun, ruler of the fifth house, is in its exaltation in Aries at seventeen degrees; the moon is in its domicile in Cancer at fourteen degrees. Here, an itthaśāla configuration is present between the sun and Mars, the ruler of the matter sought and the ruler of the ascendant, [respectively], and the moon, too, forms an itthaśála with them both. Thus a superior/superior kambüla is produced. It accomplishes the matter sought [in a fashion] superior among the superior, that is, it inevitably accomplishes the matter, namely, obtaining children.

31 But as Yādava's classification comprises five rather than four categories, it still does not correspond exactly to Balabhadra's. 


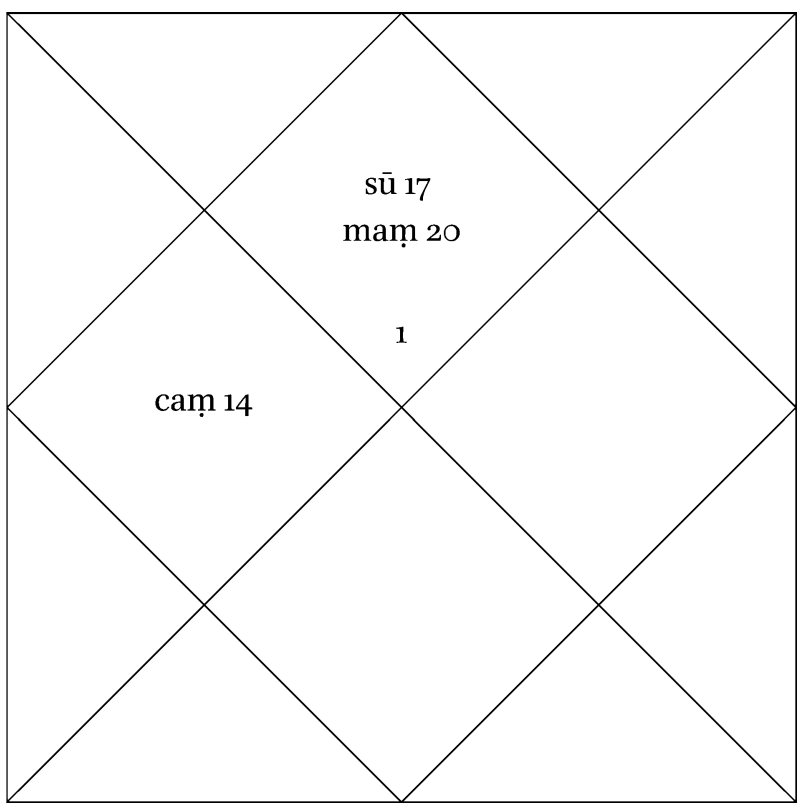

uttamottamakambūlam

atra lagnādhīśakāryeśayor muthaśilasattve candro dvayor anyatareṇa muthaśilaṃ cet karoti tadāpy uttamottamakambūlaṃ syād iti yādavah | atrodāharaṇam āha sa eva |

meșe 'ñge 'vanijo navāmśaka inah siṃhe kubhāgah śaśí

karke piṇdalavo hi cottamatamạ̣ kambülayogaḥ śubhaḥ| iti |

atra lagneśakāryeśābhyāṃ candro muthaśilaṃ karotīti mukhyaḥ pakṣah || athānyeșāṃ kambūlayogānāṃ saṃñāatantroktalakṣaṇāni svakṛtodāharaṇasahitāni likhyante | tatrottamamadhyama-uttamasamayor lakșaṇe |

1 candro] candre B N G $\quad$ 2-3 atrodāharaṇam āha] atrodāharaṇa B $\quad 5$ tamaḥ] scripsi; matạ̣ B N G K T M $\quad 6$ atra] atha B N G \| kāryeśābhyāṃ] kāryeśāṇāṃ B N G 8 sahitāni] sahitā B N G a.c. || madhyama-uttama] madhya-uttama B N G; madhyottama M

4-5 meșe ... śubhah] TYS 6.24

5 tamah] The emendation, required by the context, is supported by MS TYS1. 


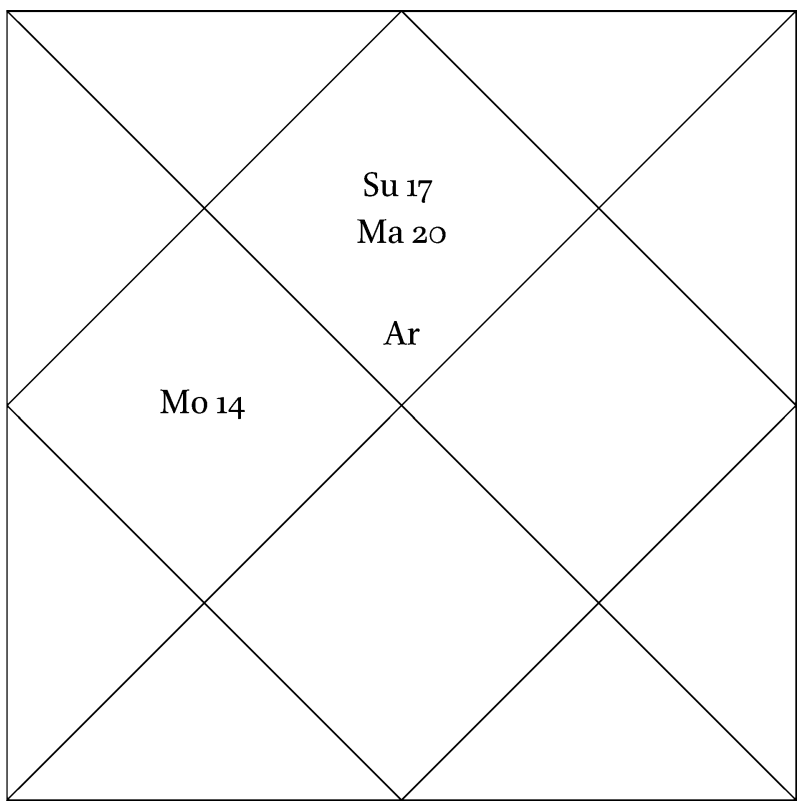

A superior/superior kambūla

Regarding this, Yādava says that when a mutthaśila is present between the ruler of the ascendant and the ruler of the matter sought, if the moon forms a mutthasila with either of the two [and not with the other], even then there is a superior/superior kambüla; and he gives an example [in Tãjikayogasudhānidhi 6.24]:

[If] Mars is in Aries in the ascendant at nine degrees, the sun in Leo at one degree, and the moon in Cancer at twenty-eight degrees, [this is] a most superior, auspicious kambūla configuration.

The standard position on this matter is that [a superior/superior kambüla arises when] the moon forms a mutthaśila with [both] the ruler of the ascendant and the ruler of the matter sought.

Next, the definitions of the other kambüla configurations stated in the Samjñätantra are written, along with examples of my own making; and [first] the definitions of the superior/middling and superior/neutral [configurations, from Samjiñātantra 2.38]: 
svīyahaddādrkānāànkabhāgasthenetthaśālatah |

madhyamottamakambūlam hīnädhikrtinottamam ||

atra yadinduh svagrhoccastha ity anuvartate | hīnādhikṛtinā trividhādhikārarahitena | ko'rthaḥ| samasya g̣̣hahaddādreșkāṇanavāmśasthena lagnapena kāryapena ca | atrodāharaṇe |

bhāgyapraśne tulālagnaṃ svahaddāyāṃ daśāṃśakah | daśame samsthitah śukro bhāgyapo jñaś ca saptame \| śakrāṃśaḥ svīyahaddāyāṃ candraḥ karke navāṃśakaḥ | yoge trayānāạm kambūlam proktam uttamamadhyamam || svanāmasadṛśaṃ jñeyạ̣ praśne kambūlajaṃ phalam | evaṃ svasvanavāṃśe tu gatayor lagnakāryayoh || svagṛhoccagatasyendor jñeyo yogah sa eva hi | rājyapraśne yugmalagnaṃ budhah kaurpye nagāṃśakaḥ || samasya jñasya gehe $t u \simeq \simeq \simeq \simeq \cup-\cup \simeq$ |

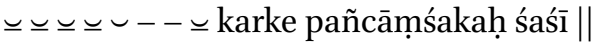

kambūlam uttamasamaṃ trayāṇām itthaśālataḥ ||

1 dṛkāṇāṅka] ddreṣkāṇāṃka B; dreṣkāṇāṃka N 4 samasya] samastha G || gṛhahaddā] gṛhaddā N 5 ca] om. K T M \|| atrodāharaṇe] atrodāharaṇaṃ N G 9 uttamamadhyamam] uttamadhyamaṃ B 11 kāryayoḥ] kāryapoḥ B N G 12 g̣̣hocca] grahocca G || gatasyendor] gatasyeṃdau B N; gatasyeṃdaur G

1-2 svīya ... kṛtinottamam] ST 2.38 3 yadīnduh ... stha] ST 2.37 
From an itthaśâla with [a planet] occupying its own haddā, decan, or ninth-part [arises] a middling/superior kambüla, [or] a superior one [formed] with [a planet] of little dignity.

Here, [the phrase] 'If the moon occupies its own domicile or exaltation' is supplied from the earlier [verse]. 'With [a planet] of little dignity' [means] with one bereft of the three kinds of dignity. What does that mean? [The configuration] of a neutral [planet] with the ruler of the ascendant and the ruler of the matter sought occupying their domicile, hadda, decan or ninthpart. Here are two examples:

In a question on good fortune, Libra is the ascendant; Venus occupies the tenth [house] at ten degrees, in its own haddā; Mercury, ruler of the ninth house, is in the seventh at fourteen degrees, in its own haddā; and the moon in in Cancer at nine degrees. By the configuration of the three, a superior/middling kambüla is declared. The results produced by the kambu its name. The same configuration should likewise be understood [to arise] between the moon placed in its own domicile or exaltation and [the rulers of] the ascendant and the matter sought placed in their respective ninthparts.

In a question on [achieving] dominion, Gemini is the ascendant; Mercury is in Scorpio at seven degrees; in the sign of the neutral Mercury [...] the moon is in Cancer at five degrees. ${ }^{32}$ By the itthaśäla of the three, a superior/neutral kambüla [arises].

32 At least half a stanza, describing the position of Jupiter, is missing from all available text witnesses, suggesting an omission early in the textual tradition. The accompanying figures show Jupiter at $9^{\circ}$ Virgo. 


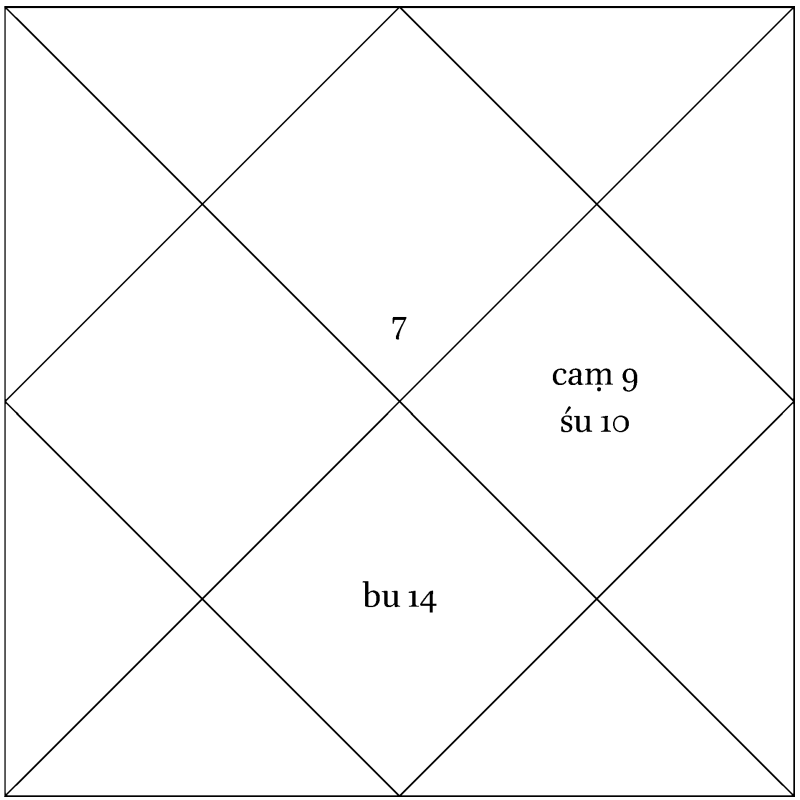

uttamamadhyamakambūlam

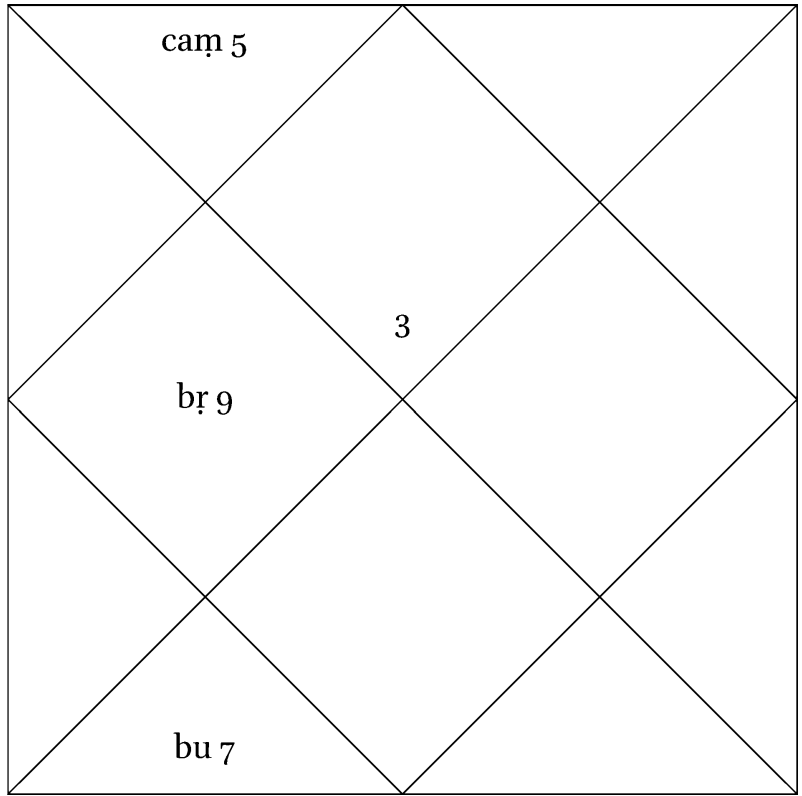

uttamasamakambūlam 


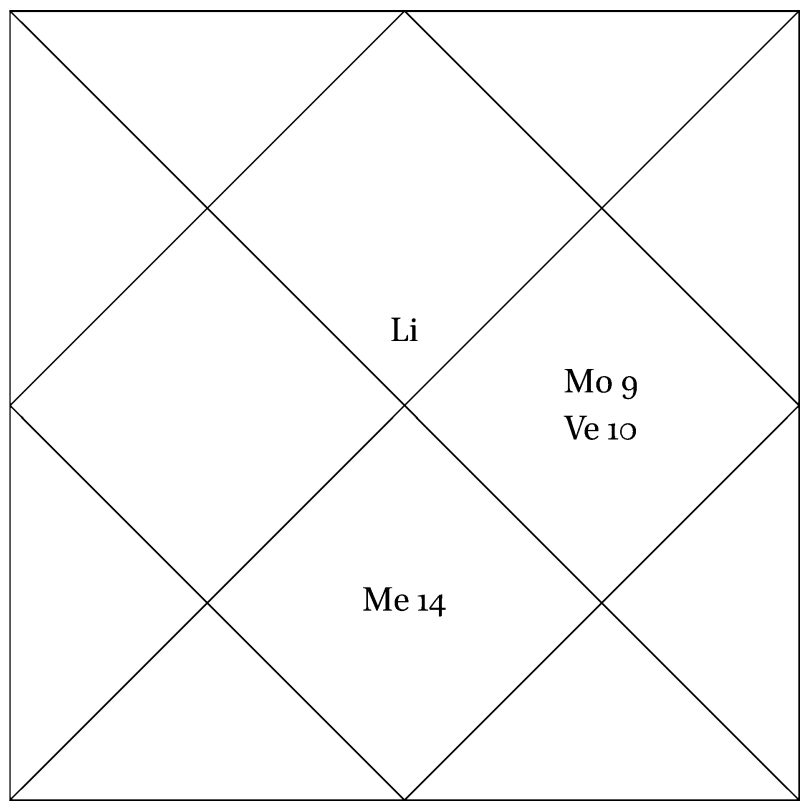

A superior/middling kambūla

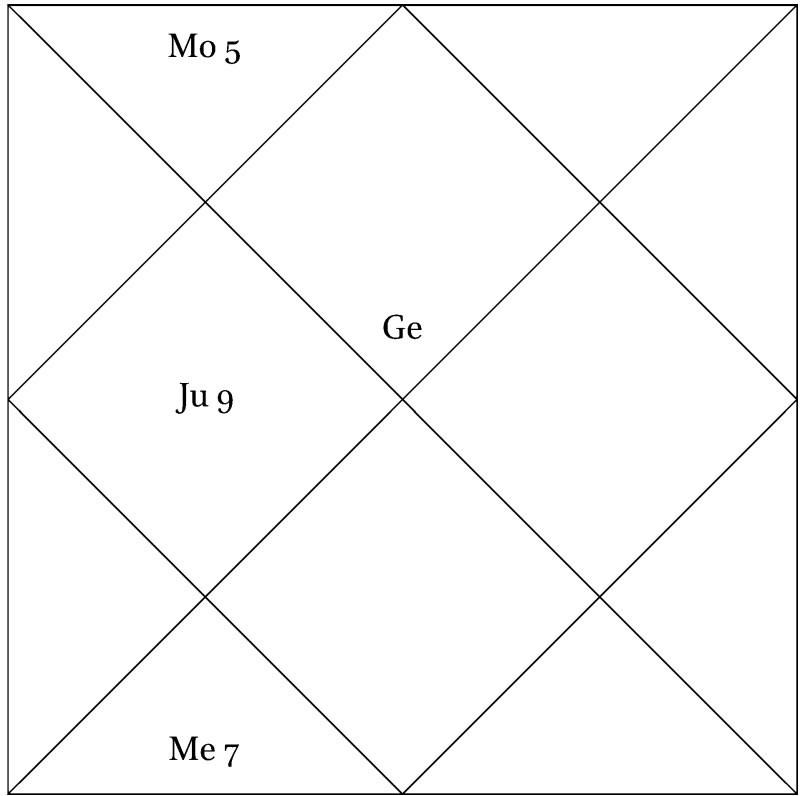

A superior/neutral kambūla 
athottamādhamakambūlalakșaṇam |

uttamādhamatā nīcaripugehasthitena cet $\mid$

atrāpi yadīnduḥ svagṛhoccastha ity anuvartate | udāharaṇam |

praśne strīlabhasamjñ̃e tu tulālagnaṃ ca bhārgavaḥ |

svanīce yuvatīrāśau daśāṃśạ saptamādhipah ||

kujaḥ svanīce sūryāṃśo vidhuh karke navāṃśakah |

trayānāām itthaśālatvāt kambūlam cottamādhamam ||

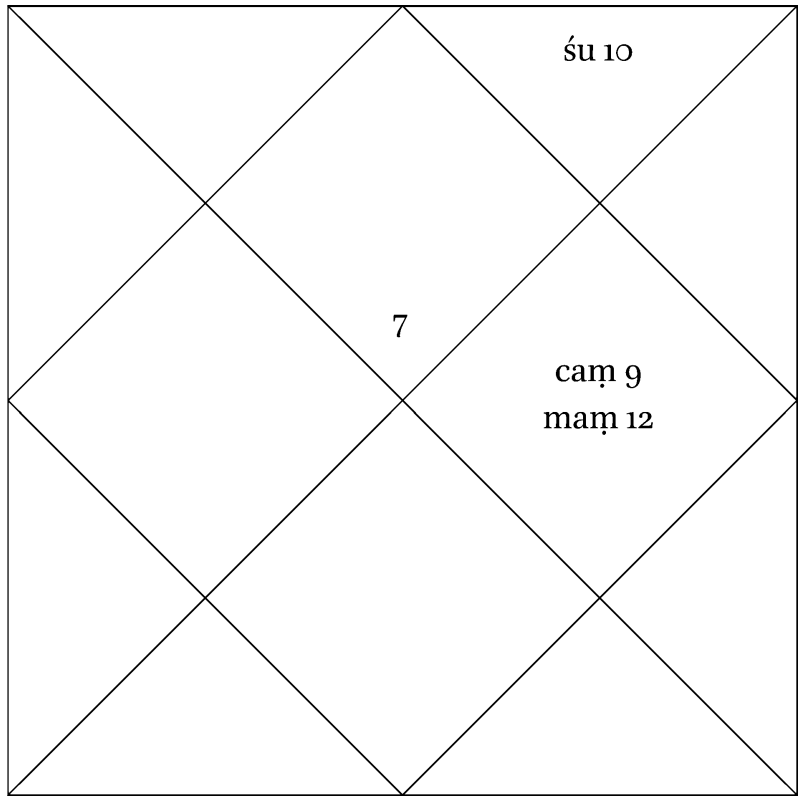

uttamādhamakambūlam

atha madhyamottamakambūlalakșaṇam |

2 uttamādhamatā ... cet] ST $2.39 \quad 3$ yadīnduh ... stha] ST 2.37 
Next, the definition of a superior/inferior kambūla [from Samjñātantra 2.39]:

It is superior/inferior if [the configuration is] with [a planet] occupying its fall or an enemy sign.

Here, too, [the phrase] 'If the moon occupies its own domicile or exaltation' is supplied from the earlier [verse]. An example:

In a question on the topic of obtaining a wife, Libra is the ascendant; Venus is in its fall in the sign of Virgo, at ten degrees; Mars, ruler of the seventh [house], is in its fall at twelve degrees; and the moon is in Cancer at nine degrees. By the three forming an itthaśăla, a superior/inferior kambūla [arises].

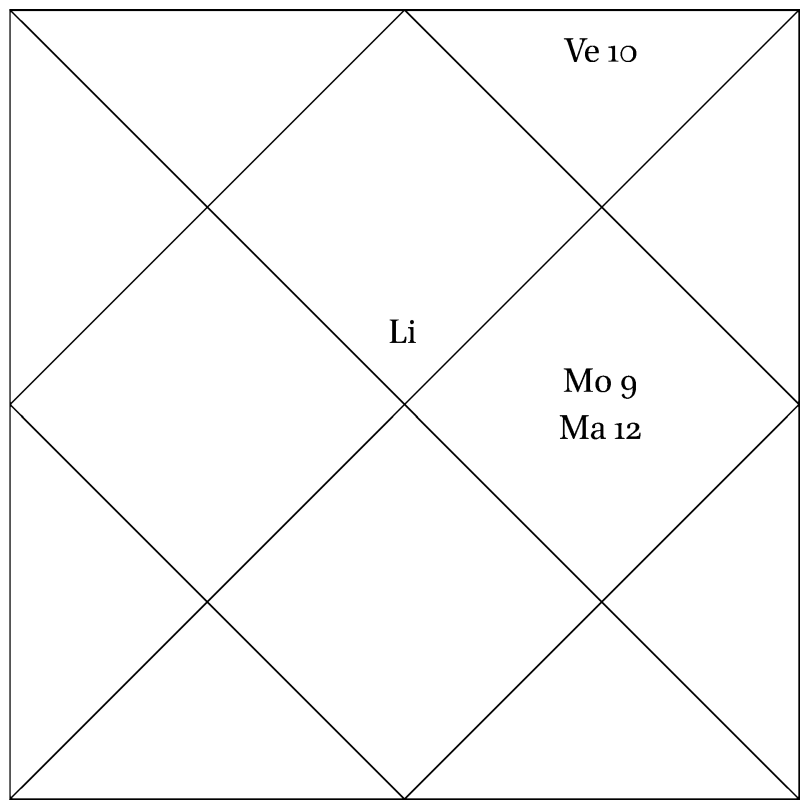

A superior/inferior kambūla

Next, the definition of a middling/superior kambūla [from Saṃñātantra 2.39-40]: 
svahaddādigataś candrah svabhoccasthetthaśālakrt | madhyamottamam etac ca pūrvasmān na viśisyate \|

pūrvasmād uttamamadhyamakambūlāt | udāharaṇam |

bhāminīlābhake praśne tulālagnaṃ tulopagah | śukro ghanāṃśo jāyeśo dhṛtyamiśo meṣagaḥ kujạ || svanavāṃśagataś candro meșarkṣe dvādaśāmśakah | trayānāam itthaśālatvāt kambūlaṃ madhyamottamam ||

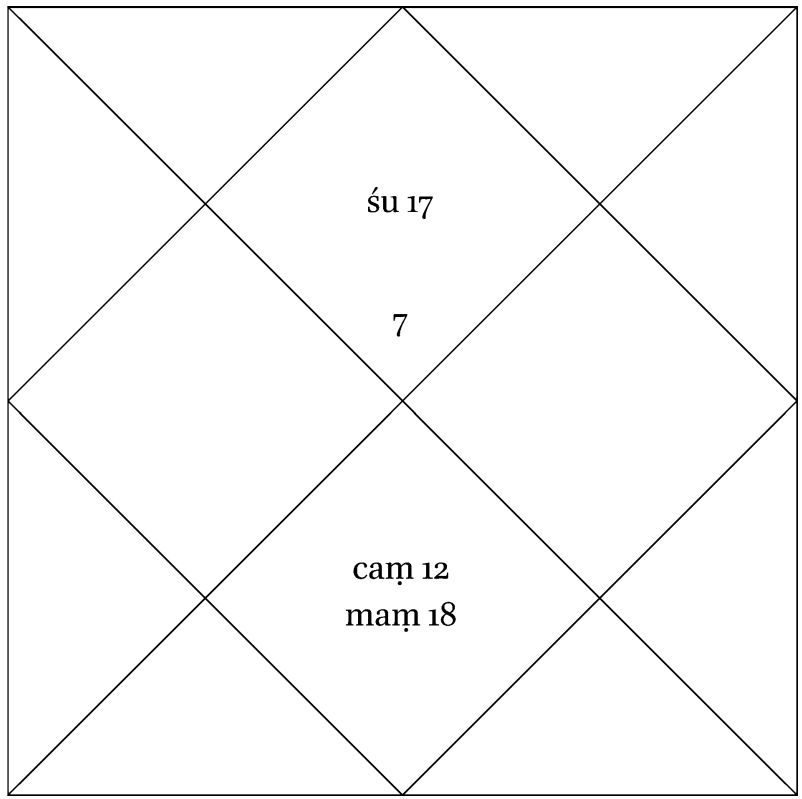

madhyamottamakambūlam

5 ghanāṃśo] dhanāṃśo K T M

1-2 sva ... viśișyate] ST 2.39-40 
[If] the moon, occupying its own haddā and so forth, forms an itthaśāla with [a planet] occupying its own domicile or exaltation, this is a middling/superior [kambüla], no different from the foregoing. ${ }^{33}$

'From the foregoing' [means] from a superior/middling kambüla. An example:

In a question on obtaining a wife, Libra is the ascendant; Venus is in Libra at seventeen degrees; Mars, ruler of the seventh house, is in Aries at eighteen degrees; the moon is in its own ninth-part in the sign of Aries, at twelve degrees. By the three forming an itthaśäla, a middling/superior kambüla [arises].

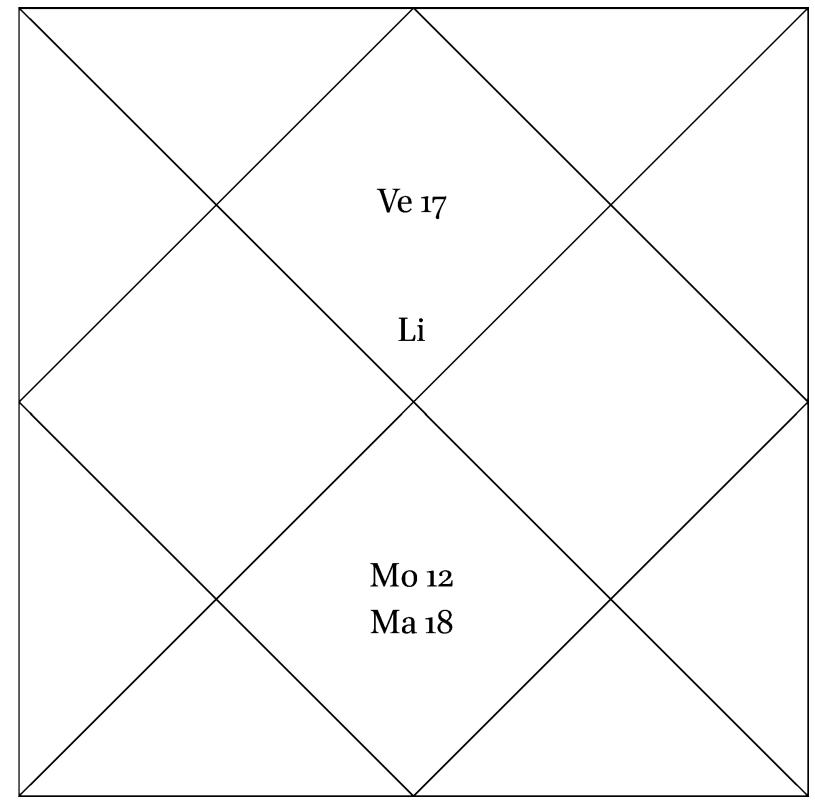

A middling/superior kambūla

33 The choice of phrasing is not ideal, as the moon does not rule any terms (haddā): these belong only to the five true or non-luminary planets. The moon does, however, have its own decans and ninth-parts, which, in Nilakanțha's and Balabhadra's view, belong to the same class of minor dignities. Independent witnesses of the Samjñätantra read: '[If] the moon, occupying its own decan [or ninth]-part ...' 
atha madhyamadhyamakambūlalakṣaṇam |

svahaddādipadasthena kambūlaṃ madhyamadhyamam |

atra svahaddādigataś candra ity anuvartate | udāharaṇam |

putrapraśne yugmalagnaṃ jñas tulāyāṃ nagāṃśakah | svahaddāyāṃ sthitaḥ śukraḥ pañcameśo 'șțamāṃśakah ||

mithune svīyahaddāyāṃ vidhur jūke nagāṃśakah |

svatribhāgagato yoge kambūlaṃ madhyamadhyamam ||

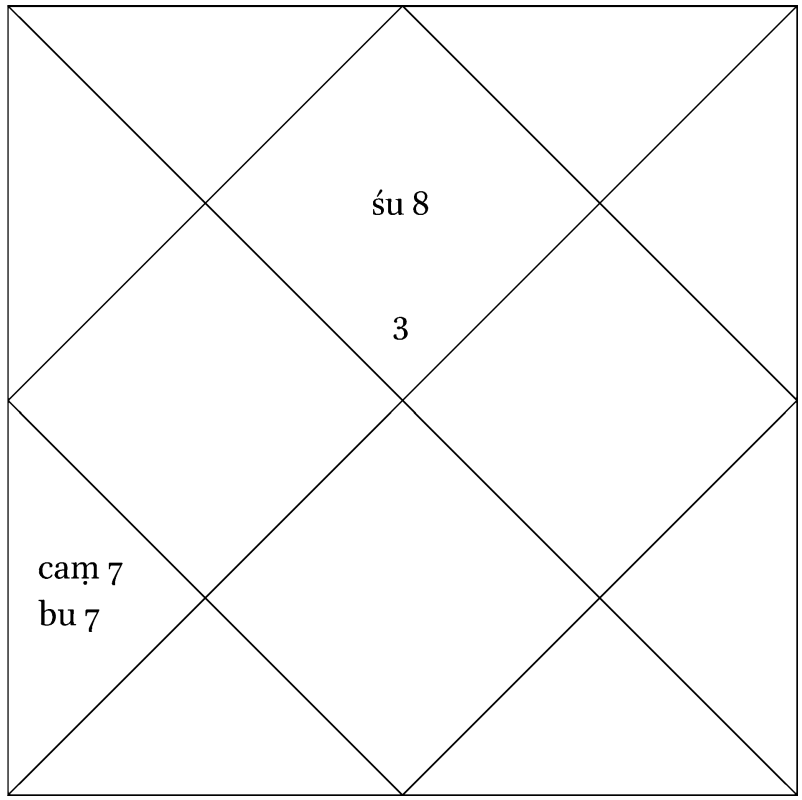

madhyamamadhyamakambūlam

yoge itthaśālākhye | atha madhyamasamakambūlalakșaṇam |

madhyamaṃ samakambūlaṃ hīnādhikrtikhețajam |

3 atra] atha B N $\|$ haddādi] gṛhādi B N G 6 vidhur jūke] vidhūrjake B; vidhūrjuke G 8 yoge ittha-] yogottha B N G

2 sva ... madhyamam] ST $2.40 \quad 3$ sva ... candra] ST $2.39 \quad 9$ madhyamam ... khețajam] ST 2.41 
Next, the definition of a middling/middling kambüla [from Samjñātantra 2.40]:

The kambüla is middling/middling if [the the moon is configured] with [a planet] occupying a dignity beginning with its own haddā.

Here, [the phrase] '[If] the moon, occupying its own hadda and so forth' is supplied from the earlier [verse]. An example:

In a question on children, Gemini is the ascendant; Mercury is placed in Libra at seven degrees, in its own haddā; Venus, ruler of the fifth [house], is at eight degrees in Gemini, in its own haddā; the moon is in Libra at seven degrees in its own third-part. In [this] configuration, the kambūla is middling/middling.

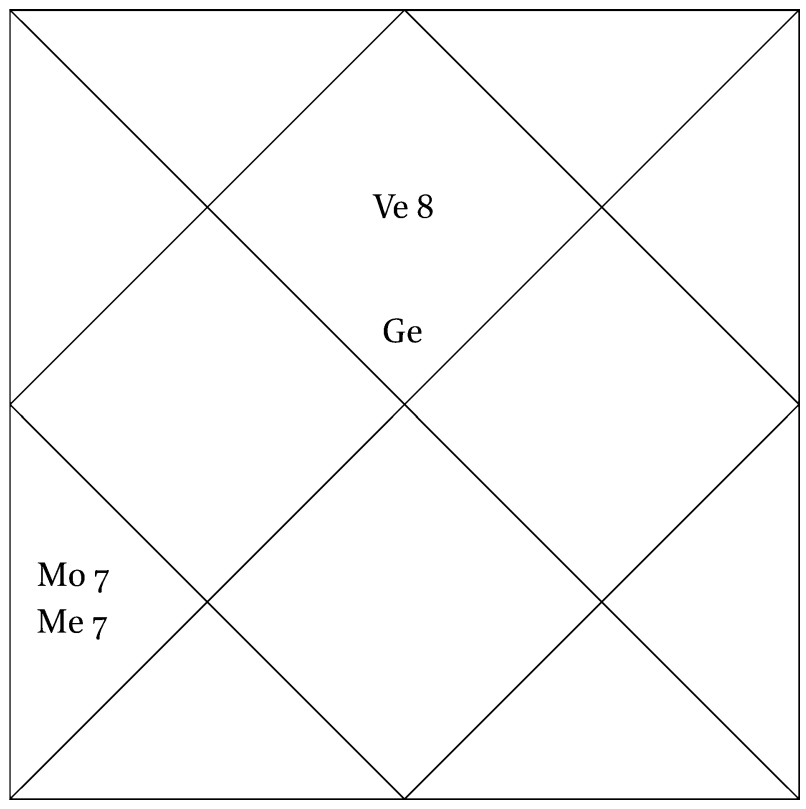

A middling/middling kambūla

'In [this] configuration', namely, itthaśäla. Next, the definition of a middling/neutral kambüla [from Saṃjñätantra 2.41]:

The kambüla is middling/neutral when produced by a planet with little dignity. 
atrāpi svahaddādigataś candra ity anuvartate | udāharaṇam |

vṛṣalagnaṃ sutapraśne mṛge vedāṃśakaḥ sitah |

samasya jñasya haddāyāṃ suteśo jñah śarāṃśakah ||

tulāyāṃ samamandasya haddāstho jūkagaḥ śaśî |

rāmāṃśạ̣ svatribhāge tu kambūlaṃ madhyamaṃ samam ||

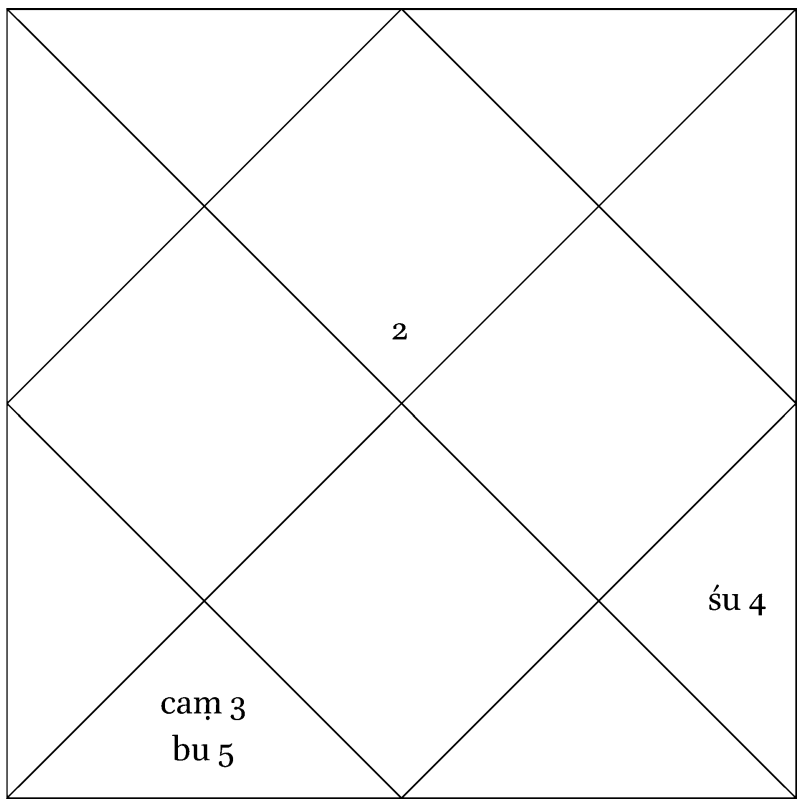

madhyamasamakambūlam

atha madhyamādhamakambūlalakṣaṇam |

madhyamādhamakambūlaṃ nīcāribhagakhețajam |

atrāpi svahaddādigataś candra ity anuvartate | udāharaṇam |

1 haddādigataś] scripsi; gṛhādigataś B N G M; gṛhādigaś K T || anuvartate] anuvatte N

1 sva ... candra] ST $2.39 \quad 7$ madhyamādhama ... khețajam] ST $2.41 \quad 8$ sva ... candra] ST 2.39 
Here, too, [the phrase] '[If] the moon, occupying its own haddā and so forth' is supplied from the earlier [verse]. An example:

In a question on children, Taurus is the ascendant; Venus is in Capricorn at four degrees, in the haddā of the neutral Mercury; Mercury, ruler of the fifth house, is in Libra at five degrees, in the hadda of the neutral Saturn; the moon is in Libra at three degrees, in its own third-part: the kambüla is middling/neutral.

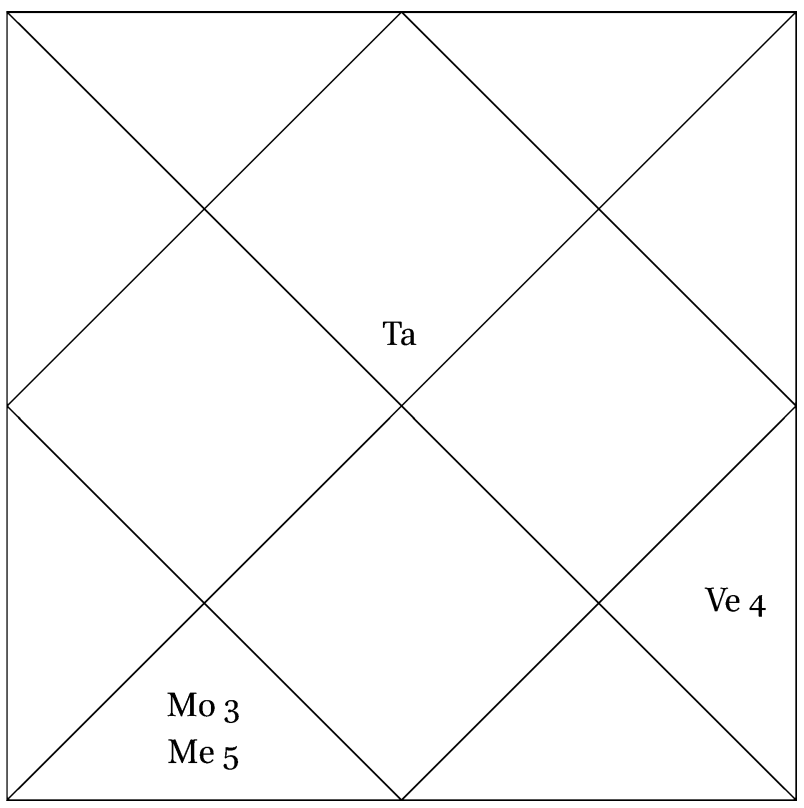

A middling/neutral kambūla

Next, the definition of a middling/inferior kambūla [from Saṃjñätantra 2.41]:

The kambüla is middling/inferior when produced by a planet in its fall or the sign of an enemy.

Here, too, [the phrase] '[If] the moon, occupying its own hadda and so forth' is supplied from the earlier [verse]. An example: 
bhāgyapraśne meșalagnaṃ bhaumaḥ karke navāṃśakaḥ| gurur bhāgyādhipo nīce makare ca daśāṃśakaḥ || svadreṣkānagataś candras tulāyāṃ pañcabhāgakaḥ | trayāṇām itthaśālatvāt kambūlaṃ madhyamādhamam ||

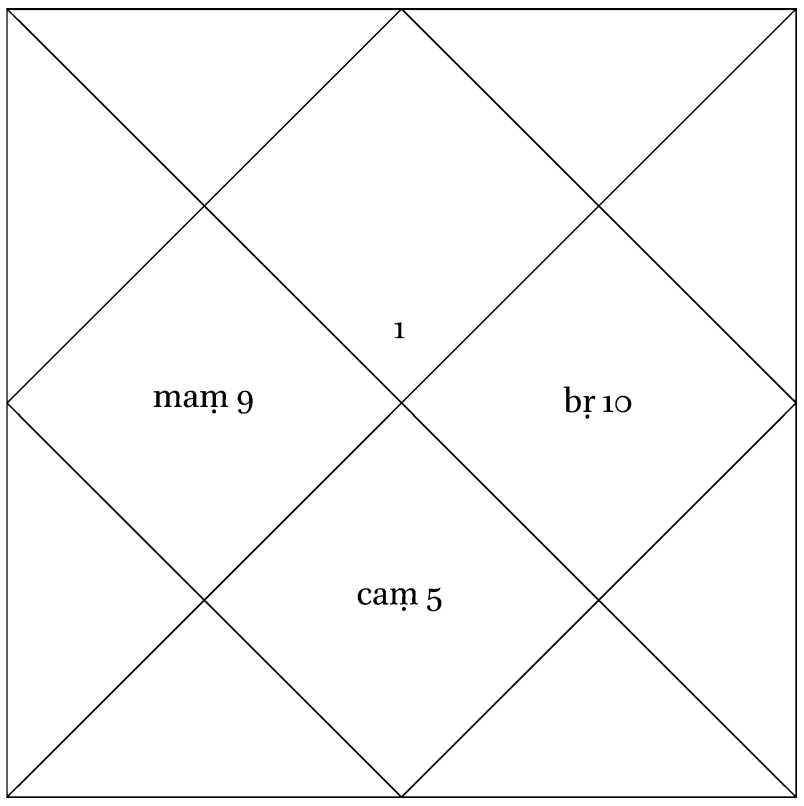

madhyamādhamakambūlam

atha samottamakambūlalakṣaṇam |

induḥ padonaḥ svarkṣoccasthitenāpy uttamam tu tat |

atra padonatvaṃ dvividham | ekaṃ tāvat grahāṇāṃ samag̣̣hasamahaddāsamadreṣkāṇasamanavāṃśagatvam | dvitīyam sūkṣme prativikalārūpe

6 tat] yat B N G 7 padonatvaṃ] padonaṃ K M $\|$ haddā] ddāha N; haddāsamaddā K 8 dreṣkāṇa] dreṣkāṇe T M || -gatvam] -gatatvam K T $\quad 8$-312.1 'sama] scripsi; sama B N G K $\mathrm{T} \mathrm{M}$

6 induh ... tat] ST 2.42

8-312.1 'sama] The emendation is required by the explication following shortly below. The avagraha is often, though not consistently, omitted by all text witnesses. 
In a question on good fortune, Aries is the ascendant; Mars is in Cancer at nine degrees; Jupiter, ruler of the ninth house, is in its fall in Capricorn at ten degrees; the moon is in its own decan in Libra at five degrees. By the three forming an itthaśāla, a middling/inferior kambūla [arises].

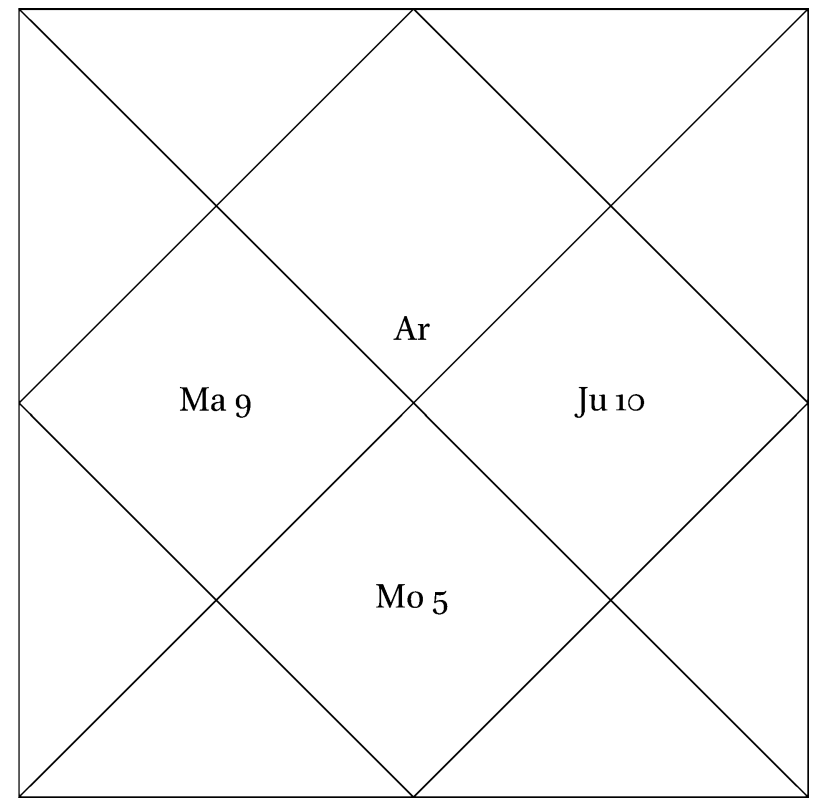

A middling/inferior kambūla

Next, the definition of a neutral/superior kambūla [from Samjñātantra 2.42]:

[If] the moon without dignity [is configured] with [a planet] occupying its own domicile or exaltation, that is superior.

Concerning this, lack of dignity is of two kinds. One of them is when the planets occupy a neutral domicile, a neutral haddā, a neutral decan, and a neutral ninth-part. The second, minute form, concerning seconds of arc, is 
'samagṛhahaddādreṣkāṇanavāṃśānām ādau prānte vāvasthitatvam iti jīrṇațịkākṛt | udāharaṇam |

dhanalābhābhidhe praśne tulālagnaṃ ca bhārgavaḥ | tulāyāṃ nagabhāgaś ca dhaneśo makare kujạ || navāṃśo mithune candro jñahaddāyāṃ śarāṃśakah | indoḥ samo jñah kambūlaṃ yoge proktaṃ samottamam ||

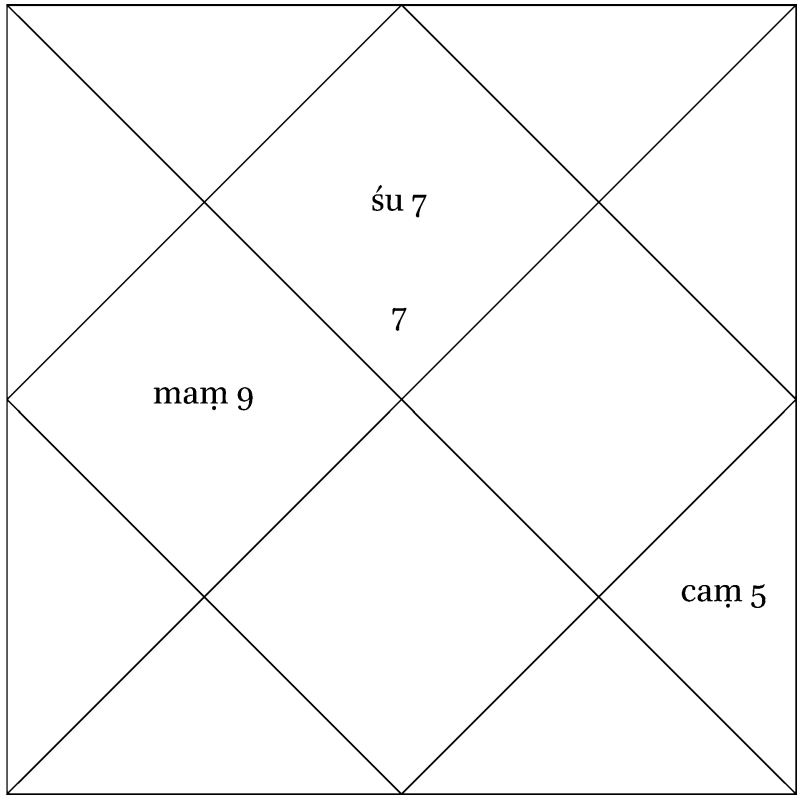

samottamakambūlam

atha samamadhyamakambūlalakṣaṇam |

svahaddādigatenāpi pūrvavan madhyam ucyate |

atrāpi induḥ padona ity anuvartate | udāharaṇam |

1 gṛhahaddā] grahahaddā B G p.c.; grahaddāhe N; grahaddā G a.c. 1-2 jīrṇa] om. B N G 6 yoge] yogam B G; yoga N 7 atha] om. B N G a.c.

8 sva ... ucyate] ST $2.42 \quad 9$ induh padona] ST 2.42 
when they are located at the [very] beginning or end of a domicile, haddā, decan or ninth-part that is not neutral: so says the ancient commentator. An example:

In a question on the topic of gaining wealth, Libra is the ascendant; Venus is in Libra at seven degrees; Mars, ruler of the second house, is in Capricorn at nine degrees; the moon is in Gemini in the hadda of Mercury at five degrees. Mercury is neutral to the moon. In [this] configuration, the kambüla is declared to be neutral/superior.

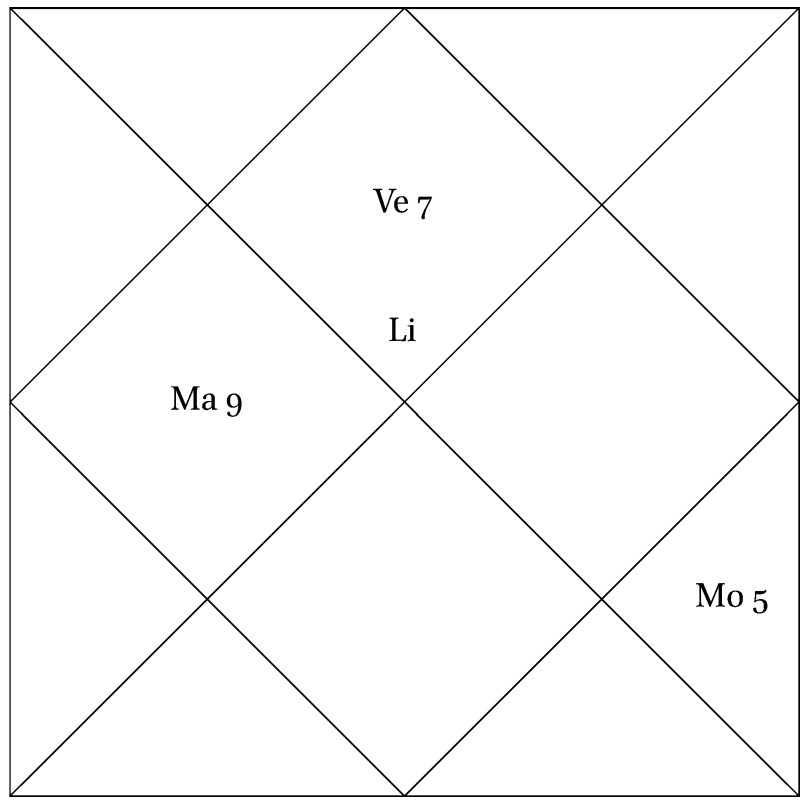

A neutral/superior kambūla

Next, the definition of a neutral/middling kambūla [from Saṃjñātantra $2.42]$ :

[When configured] with [a planet] occupying its own haddā and so on, [the kambüla] is called middling, as before.

Here, too, [the phrase] '[If] the moon without dignity' is supplied from the earlier [verse]. An example: 
dhanapraśne tulālagnaṃ śukrah siṃhe daśāṃśakaḥ | svahaddāyāṃ dhanādhīśo bhaumaś cāpe digaṃśakah || svahaddāyāṃ ca mithune samaśukrasya haddagaḥ | vidhur daśāṃśo yoge syāt kambūlaṃ samamadhyamam ||

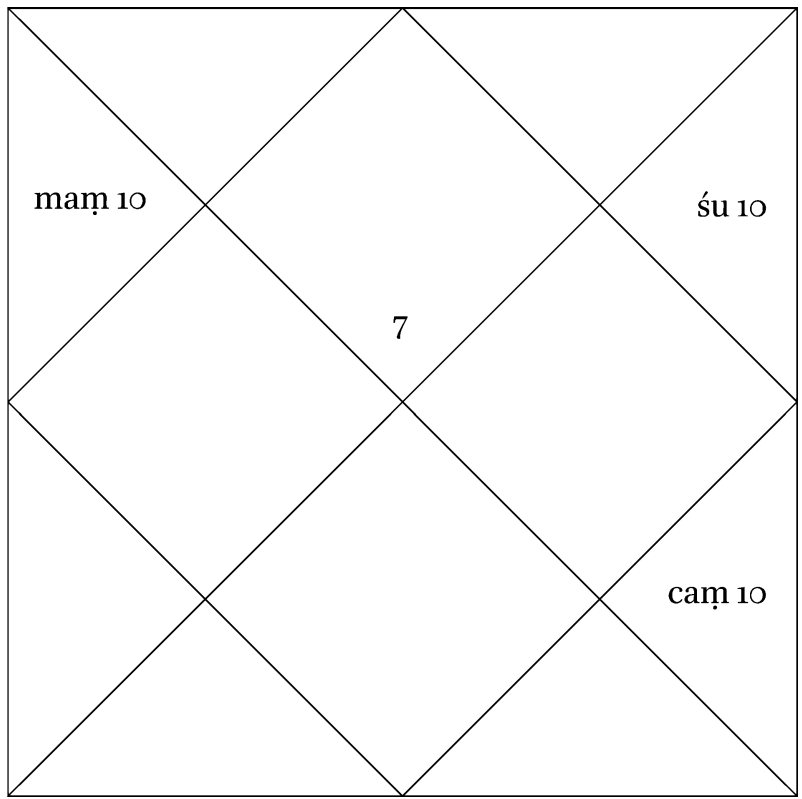

samamadhyamakambūlam

atha samasamākhyamadhyamakambūlalakṣaṇam |

padonenāpi madhyam syād iti yuktam pratīyate |

3 sama] samaḥ B N G 4 syāt] smāt K T; 'smāt M

6 padonenāpi ... pratīyate] ST 2.43 
In a question on wealth, Libra is the ascendant; Venus is in Leo at ten degrees, in its own haddā; Mars, ruler of the second house, is in Sagittarius at ten degrees, in its own haddā; the moon is in Gemini in the haddā of the neutral Venus, at ten degrees. In [this] configuration, the kambüla is neutral/middling. ${ }^{34}$

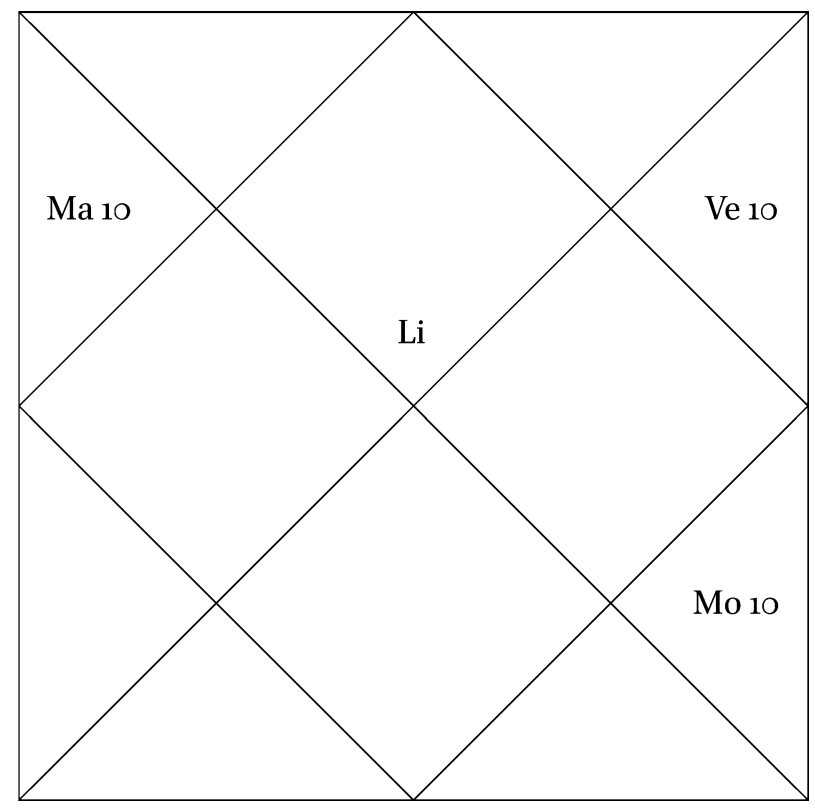

A neutral/middling kambūla

Next, the definition of the middling kambüla called neutral/neutral, [from Samjjñätantra 2.43]:

[Configured] with [a planet] lacking dignity, too, [the kambüla] is rightly acknowledged to be middling.

34 But the example is flawed, as Mars at $10^{\circ}$ Sagittarius is in Jupiter's terms, not its own: indeed, Mars at $10^{\circ}$ of any sign cannot be in its own terms. For Mars to be at $10^{\circ}$ of a neutral sign in a minor dignity and configured with the moon and Venus, it would have to occupy its own decan in Gemini. This is too large a discrepancy to be plausibly attributed to corrupt transmission. 
atra induḥ padona ity anuvartate | padonena dreșkānādisaṃdhisthena lagneśena kāryeśena ca | udāharaṇam |

dravyapraśne meșalagnaṃ bhaumaḥ siṃhe dhanādhipạ̣ | bhrgur ghaṭe vidhur jūke trayaś cāmī digamśsakāh || dreṣkāṇasaṃdhau saṃsthityā jātāś cāmī padonitāḥ | samaṃ samaṃ ca kambūlaṃ proktaṃ taditthaśālatạ ||

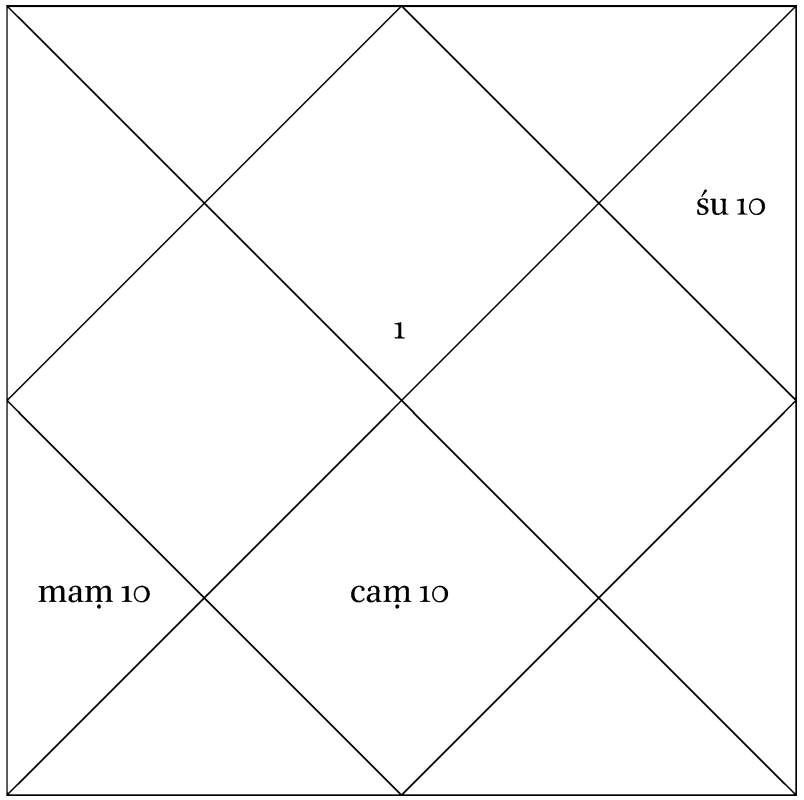

samasamakambūlam

atha samādhamakambūlalakṣaṇam |

nìcāristhenetthaśäle 'dhamakambūlam ucyate |

5 saṃsthityā] saṃsthitya K M || padonitāḥ] padonatạ̣ N; padonatāḥ $\mathrm{G}$ samaṃ] samāsamaṃ B N G 8 kambūlam] kambūla B N G

1 induh padona] ST $2.42 \quad 8$ nīcāri ... ucyate] 2.43 
Here, [the phrase] '[If] the moon without dignity' is supplied from the earlier [verse]. 'With [a planet] lacking dignity' means with the ruler of the ascendant and the ruler of the matter sought occupying the junction of a decan and so forth. An example:

In a question on riches, Aries is the ascendant; Mars is in Leo; Venus, ruler of the second house, is in Aquarius; the moon is in Libra; and these three are [all] at ten degrees. Being placed at the junctions of [their respective] decans, they are bereft of dignity. The kambūla [arising] from their itthaśäla is declared to be neutral/neutral. ${ }^{35}$

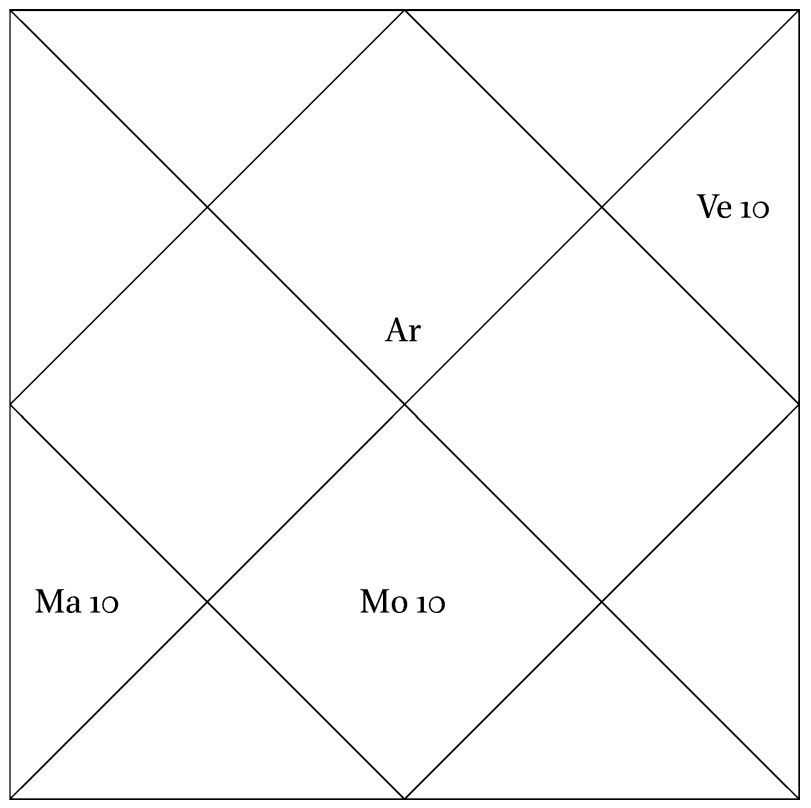

A neutral/neutral kambūla

Next, the definition of a neutral/inferior kambūla [from Samjñātantra 2.43]:

In an itthaśāla with [a planet] occupying its fall or an enemy [sign], the kambūla is said to be inferior.

35 Another flawed example: Venus and the moon would be at the very end of their own decans; but the decan of Mars is the last decan in Leo, not the first. Venus at $10^{\circ}$ Aquarius would also occupy its own terms or haddā and thus cannot properly be said to be without dignity. 
atra induḥ padona ity anuvartate | udāharaṇam |

putrapraśne yugmalagnaṃ budho mīne nagāṃśakaḥ |

suteśạ̣ kanyakāyāṃ ca daśāṃśo nīcago bhṛguh ||

samasya jñasya dreṣkāne cāpe candrạ̣ śarāmśsakah |

trayāṇām itthaśâlatvāt kambūlaṃ ca samādhamam ||

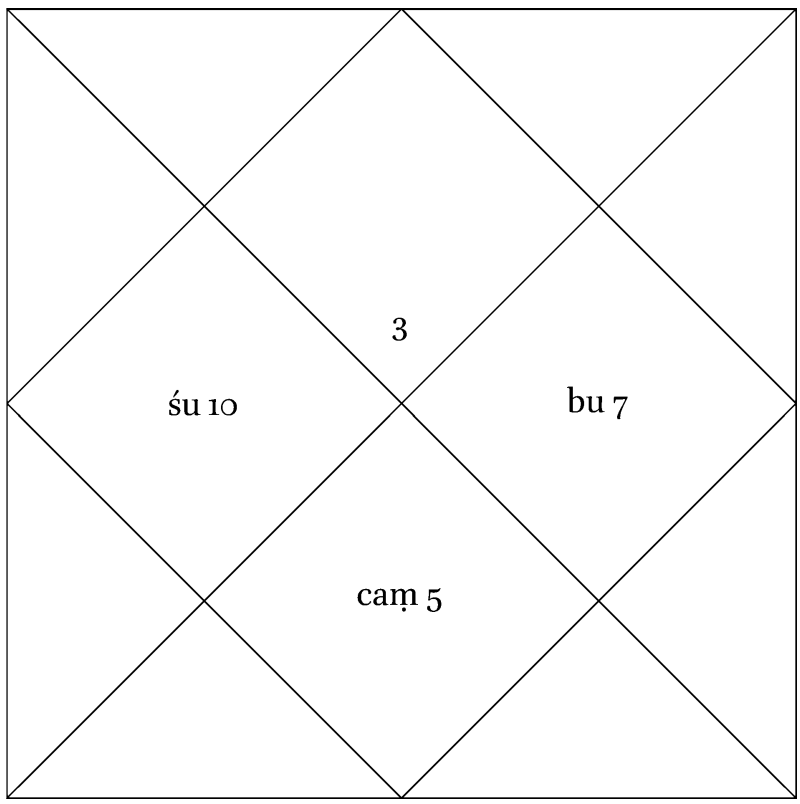

samādhamakambūlam

athādhamottamakambūlalakṣaṇam |

nīcaśatrubhagaś candraḥ svabhoccasthetthaśālakrt |

adhamottamakambūlam || iti |

1 atra] om. B N G 2 nagāṃśakah] navāṃśakah K T M 4 jñasya] om. B N $\quad$ 6-320.7 athā- ... madhyamam] om. B N

1 induh padona] ST $2.42 \quad 7-8$ nīca ... kambūlam] ST 2.44 
Here, [the phrase] '[If] the moon without dignity' is supplied from the earlier [verse]. An example:

In a question on children, Gemini is the ascendant; Mercury is in Pisces at seven degrees; Venus, ruler of the fifth house, is in its fall in Virgo at ten degrees; the moon is in the decan of the neutral Mercury in Sagittarius at five degrees. By the three forming an itthaśâla, a neutral/inferior kambüla [arises]. ${ }^{36}$

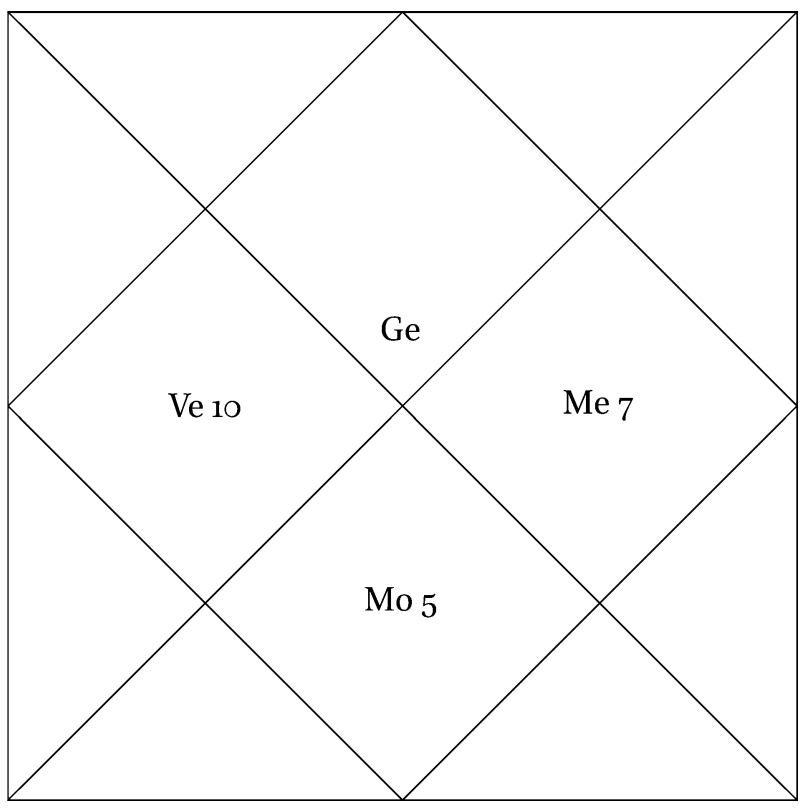

A neutral/inferior kambūla

Next, the definition of an inferior/superior kambüla [from Saṃjñätantra 2.44]:

[If] the moon, placed in its fall or an enemy sign, forms an itthaśāla with [a planet] occupying its own domicile or exaltation, [that is] an inferior/superior kambūla ... ${ }^{37}$

36 This example, too, is flawed, as the position of Mercury and Venus in opposite zodiacal signs is astronomically impossible. Even assuming simultaneous maximum and opposite elongations for both planets, the greatest possible distance between them is some $75^{\circ}$, or two and a half signs.

37 Balabhadra omits the last quarter-stanza: '... giving the same result as the foregoing.' 
udāharaṇam |

sukhapraśne siṃhalagnaṃ raviḥ saptāṃśakah kriye |

sukheśo makare bhaumo navāmsśo vṛ́ścike śaśī |

tryamísas trayānāạm yoge tu kambūlam adhamottamam ||

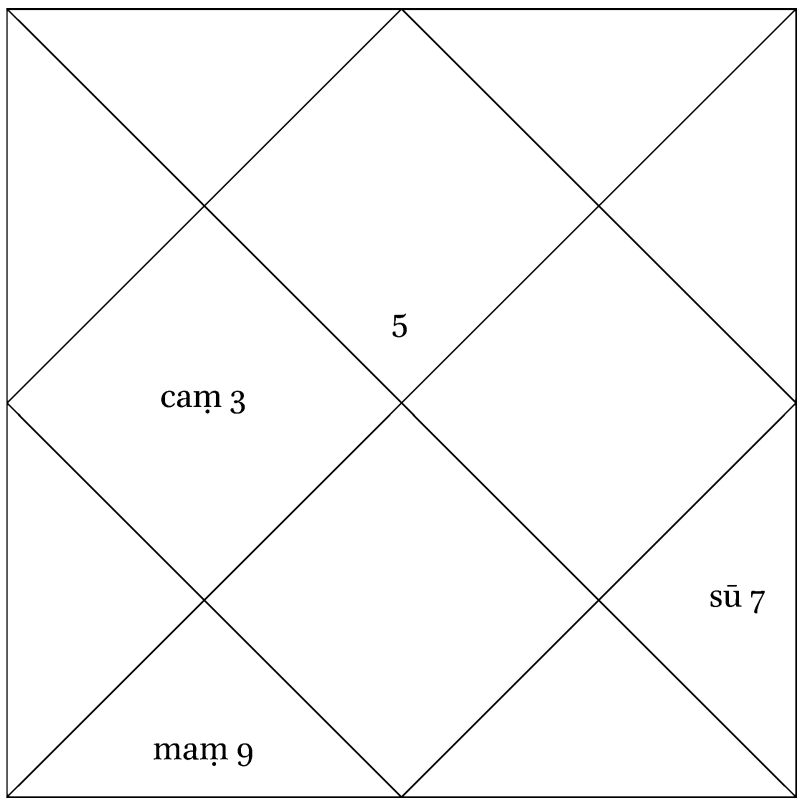

adhamottamakambūlam

athādhamamadhyamakambūlalakṣaṇam |

svahaddādigatena cet $\mid$

itthaśâlì kabūlaṃ tad ucyate 'dhamamadhyamam ||

atra nīcaśatrubhagaś candra ity anuvartate | udāharaṇam |

2 lagnaṃ] lagne T M $\quad 4$ tryaṃśas] aṃśas $\mathrm{G} \quad 6$ gatena] gate $\mathrm{M} \quad 7$ kabūlaṃ] scripsi; kaṃbūlaṃ G K M; kabūla T 8 candra] śatrubhagaś candra add. B N

6-7 sva ... madhyamam] ST $2.45 \quad 8$ nīca ... candra] ST 2.44

4 tryamśas] The reading of $\mathrm{G}$ is another instance of confusion of the characters $a$ and trya in northern-style Devanāgarī. 
An example:

In a question on happiness, Leo is the ascendant; the sun is at seven degrees in Aries; Mars, ruler of the fourth house, is in Capricorn at nine degrees; the moon is in Scorpio at three degrees. By the configuration of the three, an inferior/superior kambūla [arises].

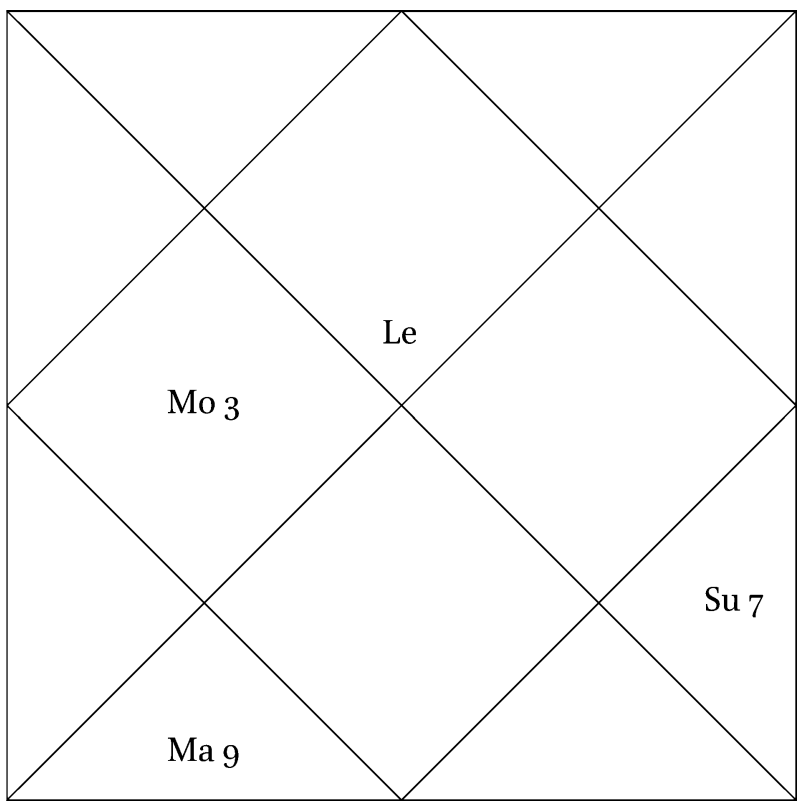

An inferior/superior kambūla

Next, the definition of an inferior/middling kambūla [from Saṃjñātantra 2.45]:

... If it forms an itthaśāla with [a planet] occupying its own haddā and so on, that kambüla is said to be inferior/middling. ${ }^{38}$

Here, [the phrase] '[If] the moon, placed in its fall or an enemy sign' is supplied from the foregoing [verse]. An example:

$38 \quad$ Balabhadra omits the first quarter-stanza: 'The moon, occupying its fall or an enemy's domicile ...', preferring instead to supply the near-identical phrase from the previous verse, perhaps for the sake of consistency. 
putrapraśne 'nganālagnam svahaddāyāṃ mṛge budhaḥ | rāmāṃśaḥ putrapo mandạ̣ svahaddāyāṃ śarāṃśakah || mīne vṛ́ścikagaś candras tryaṃśaś caișāṃ tu yogatah | proktaṃ cādhamamadhyaṃ tu kambūlaṃ śāstravedibhị̣ ||

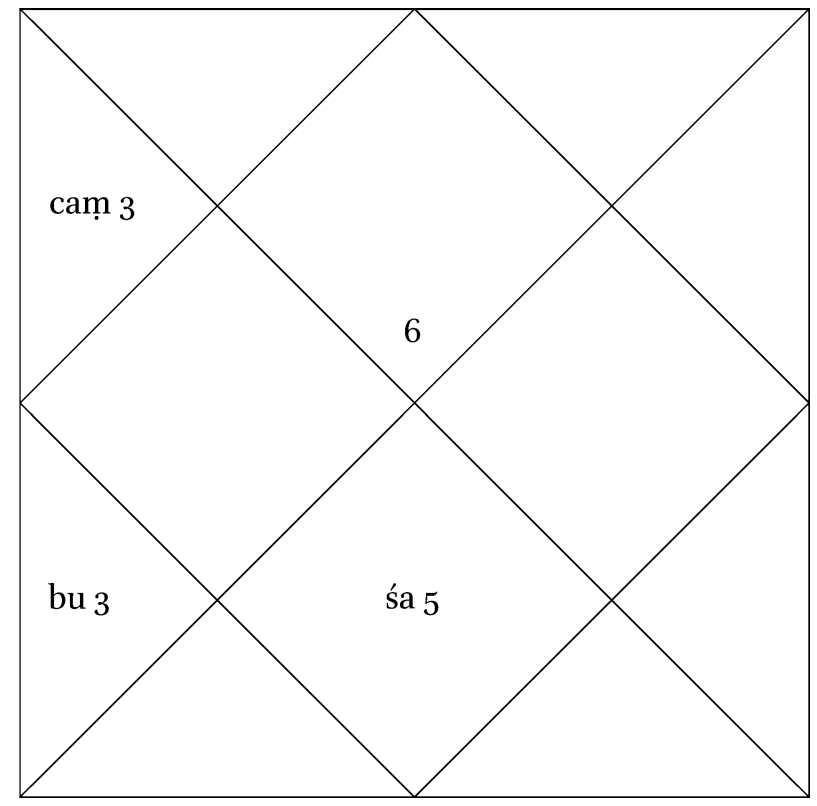

adhamamadhyamakambūlam

athādhamasamakambūlalakșaṇam |

padonenetthaśálì cet kambūlaṃ madhyamam smṛtam |

atra nīcaśatrubhagaś candra ity anuvartate | udāharaṇam |

4 kambūlaṃ] kaṃ N 6 madhyamaṃ smṛtam] samamadhyamaṃ smṛtaṃ B N; tv adhamam samam K T M

6 padonenetthaśālī ... smṛtam] ST $2.46 \quad 7$ nīca ... candra] ST 2.44 
In a question on children, Virgo is the ascendant; Mercury is in its own hadda in Capricorn at three degrees; Saturn, ruler of the fifth house, is in its own hadda at five degrees in Pisces; the moon is in Scorpio at three degrees. By the configuration of these [three], an inferior/middling kambüla is declared by the knowers of the [Tājika] science. ${ }^{39}$

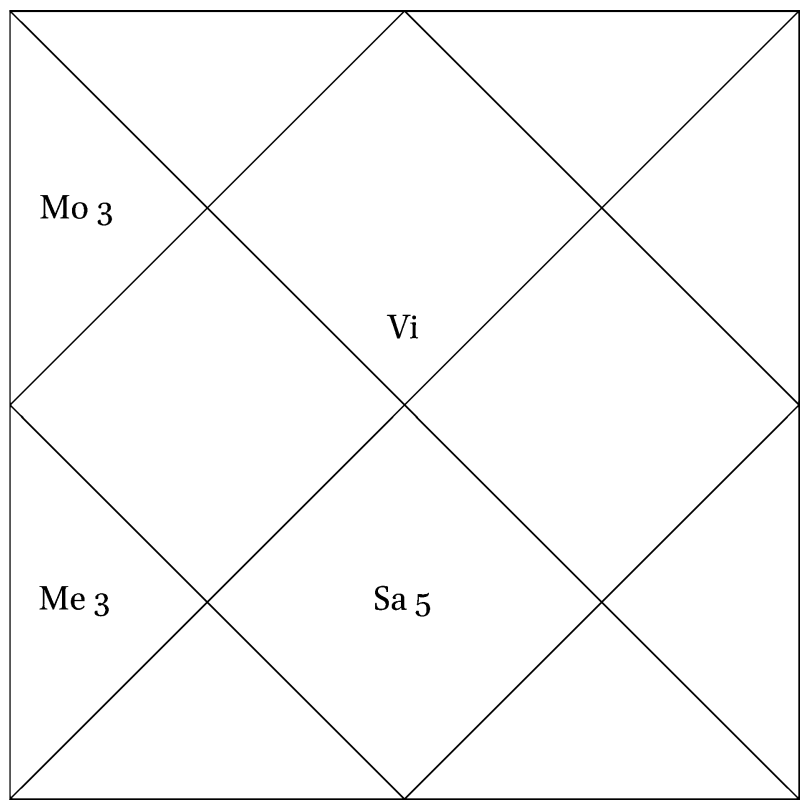

An inferior/middling kambūla

Next, the definition of an inferior/neutral kambūla [from Samjñātantra 2.46]:

If it forms an itthaśāla with [a planet] lacking dignity, the kambüla is called middling.

Here, [the phrase] '[If] the moon, placed in its fall or an enemy sign' is supplied from the earlier [verse]. An example:

39 This example has a minor flaw: Saturn at $5^{\circ}$ Pisces would be not in its own terms, but in its own decan. 
vṛ̦alagnaṃ rājyalābhapraśne siṃhagataḥ sitah | samasyārkasya gehe tu śarāṃśo rājyapaḥ śaniḥ || vrṣe samasya śukrasya gehe khendumitāmsśakah | candro vṛścikagas tryamśas trayāṇām itthaśālataḥ | kambūlaṃ cādhamasamaṃ proktaṃ tājikavedibhị̣ ||

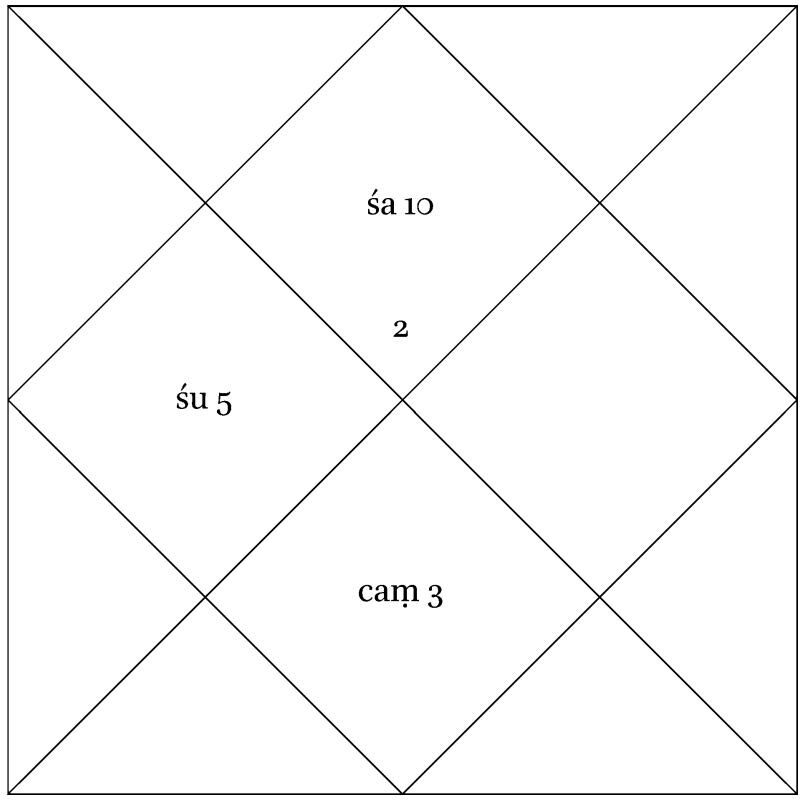

adhamasamakambūlam

athādhamādhamakambūlalakșaṇam |

nīcāribhasthakhețena nīcāribhagataḥ śaśī |

itthaśālì kabūlam tad adhamādhamam ucyate \|

udāharaṇam |

2 rājyapaḥ] madhyapah G 6 athādhamādhama] athādhama B N 8 kabūlaṃ] kambūlaṃ B N M || adhamādhamam] 'dhamādhamam G

7-8 nīcāri ... ucyate] ST 2.47 
Taurus is the ascendant in a question on achieving dominion; Venus is in Leo, the domicile of the neutral sun, at five degrees; Saturn, ruler of the tenth house, is in Taurus, the domicile of the neutral Venus, at ten degrees; the moon is in Scorpio at three degrees. By the itthaśāla of the three, an inferior/neutral kambüla is declared by the knowers of the Tājika [science].

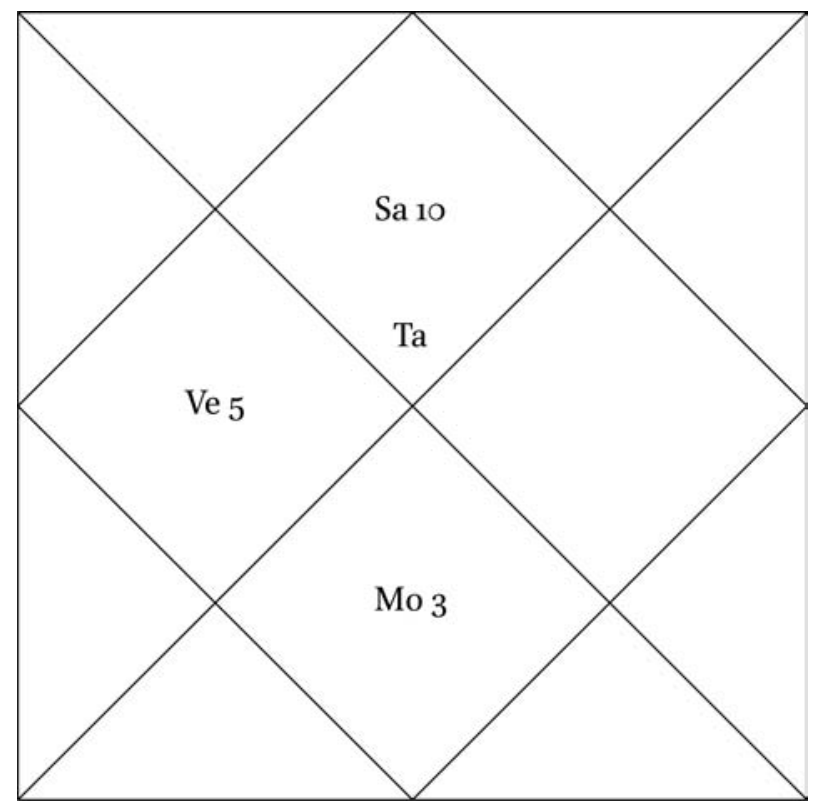

An inferior/neutral kambūla

Next, the definition of an inferior/inferior kambūla [from Samjñātantra 2.47]:

[If] the moon, placed in its fall or an enemy sign, forms an itthaśāla with [a planet] occupying its fall or an enemy sign, that kambüla is called inferior/inferior.

An example: 
putrapraśne dhanurlagnam mrge vasvamiśako guruh | karke sutādhipo bhaumaḥ pañcāṃśo vṛścike śaśî | tryaṃśas trayānāṃ yoge tu kambūlam adhamādhamam ||

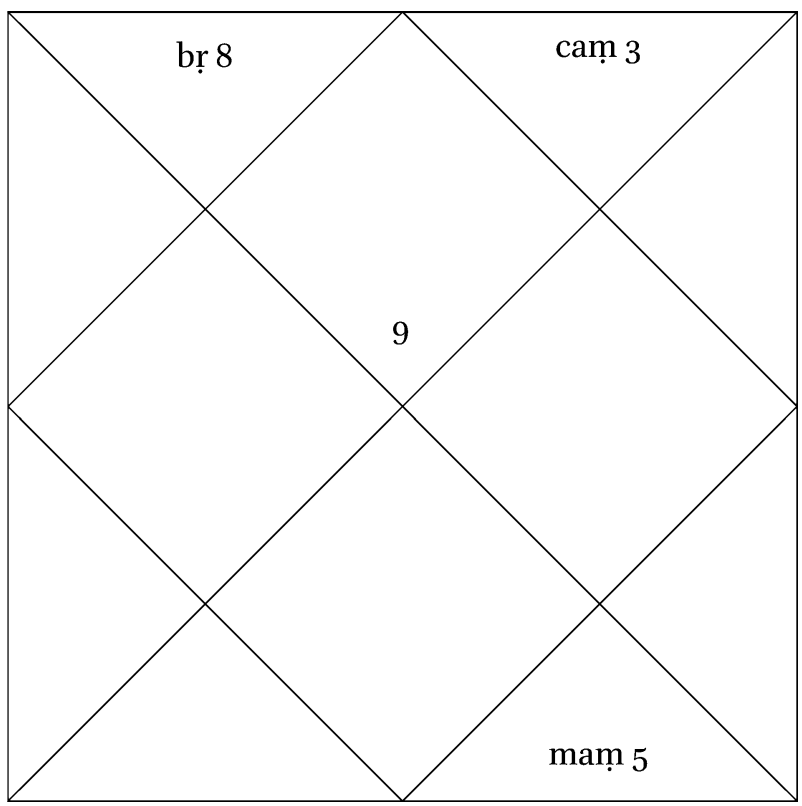

adhamādhamakambūlam

kambūle viśeșa uktaḥ saṃjñātantre |

lagnakāryapayor itthaśāle 'traiko 'sti nīcagaḥ|

svarkșādipadahīno 'nyo 'trenduh kambūlayogakrt ||

tatra kāryālpatā jñeyā yathā jātyanyam arthayan |

anyajātih pumān artham tathaitat kavayo vidụ || iti |

atha kambūlayoge viṃśopakānayanam |

1 vasvaṃśako] vasvaṃkako K M 3 kambūlam adhamādhamam] kaṃbūlaṃ madhyamādhamaṃ B; kaṃbūlaṃ dhamamādhamạ̣ $\mathrm{N} \quad 7$ jātyanyam] jñātyanyam $\mathrm{G}$

5-8 lagna ... viduh] ST 2.53-54 
In a question on children, Sagittarius is the ascendant; Jupiter is in Capricorn at eight degrees; Mars, ruler of the fifth house, is in Cancer at five degrees; the moon is in Scorpio at three degrees. By the configuration of the three, an inferior/inferior kambūla [arises].

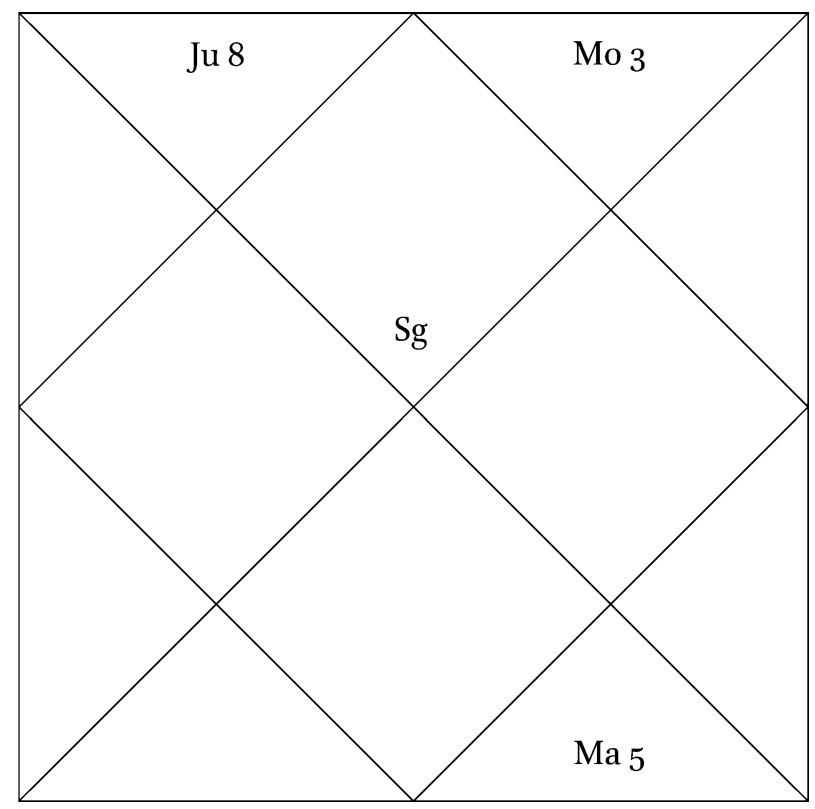

An inferior/inferior kambūla

A special rule for a kambüla is stated in Samjñātantra [2.53-54]:

In an itthaśăla between the rulers of the ascendant and the matter sought, if one [planet] is in its fall, the other lacks the dignity of domicile and so on, and the moon makes a kambüla with them, [the results pertaining to] the matter sought should be understood to be insignificant, as when a man of one caste ${ }^{40}$ requests something from one of another caste [and receives but little]: thus do the wise understand this.

Next, calculating the twenty-point strength in a kambüla configuration:

40 Or, more generally, 'birth [rank], lineage' (jāti). 
niśeśalagneśvarayor niśeśakāryeśayoḥ kāryapalagnayoś ca | vimśopakāḥ sammilitās tribhaktā viṃśopakās te kathitāḥ kabūle || iti śrīrāmadaivajñagurupādābjabhaktitah | kambūlaṃ bhedasahitaṃ balabhadreṇa nirmitam ||

iti kambūlayogah $\|$

atha gairikambūlam | tatra gairikambūlalakșaṇam āha yādavaḥ |

jātetthaśāle hy ubhayor adrșțisthāne carañ chïtarucis tayos tu| praviśya kasyāpi grham tathoccaṃ kuryād yutim gairikabūlam uktam || vadanti cainam phalataḥ samānam kambülayogasya tathaiva bhedaị | tathā hi gehaṃ na nijoccakam ca yadā tadāniștaphalạ̣ kabūlam \|

tayor lagneśakāryeśayor yutim itthaśālam | candretthaśālāvasthitasya grahasya gṛham uccaṃ vā na bhavati tadānișțam ity arthạ̣ | uktaṃ ca tājikālaṃkāre |

tatkhețagehatungastho na syād yadi ca candramāḥ| gairikambūlayogo 'sāv abhadraḥ kathito budhaih \|

atrodāharaṇaṃ saṃjñātantre |

lapsye sukham iti praśne siṃhalagnam ravih kriye | aștạmśsaị sukhapaḥ kumbhe bhaumo 'ṃśai ravibhis tayoḥ\| itthaśālo 'sti tatrenduḥ kanyāyām carame 'ṃśake | svarkșādipadahinasya netthaśālo ’sti kasyacit \|

7 hy ubhayor] dyubhayor B N; hyubhayīr M 9 cainaṃ] caitaṃ KT M 10 tadānișța] tadābhīșta B N 11 itthaśālam] itthaśālaś K T M \| candretthaśālāva-] candretthaśāva- G 11-12 grahasya] om. B N M; stha K 12 gṛham] graham K T M 14 geha] gehe B N 17 lapsye] laśye B N

7-10 jāte ... kabūlam] TYS 6.25-26 17-330.2 lapsye ... dāyakam] ST 2.58-6o 
The twenty-point strength [produced by the itthaśäla] of the moon with the ruler of the ascendant, of the moon with the ruler of the matter sought, and of the ruler of the matter sought with [the ruler of] the ascendant, added together and divided by three, is said to be the twenty-point strength in a kambūla.

With devotion to the lotus feet of his teacher Śrī Rāma Daivajña, Balabhadra thus delineates the kambüla with its subdivisions.

This concludes the kambüla configuration.

\section{9}

\section{The Gairikambüla Configuration}

Next, the gairikambūla; and Yādava states the definition of a gairikambūla [in Täjikayogasudhānidhi 6.25-26]:

When an itthaśāla is formed while the moon is passing through a sign not aspected by either of those two [planets], but, having entered the domicile or exaltation of any [planet], it will effect a joining [with that planet, that configuration] is called gairikambüla. This is said to be equal in its results to the kambüla configuration, and also in its subdivisions; but when [the sign entered] is not the domicile or the exaltation [of the planet applied to], then the [gairi] kambüla gives evil results.

'Of those two' [means] of the ruler of the ascendant and the ruler of the matter sought; 'joining' [means] itthaśäla. That is, [if] it is not the domicile or the exaltation of the planet forming an itthaśa la with the moon, it is evil. And it is said in the Tājikālaṃkāra:

And if the moon is not placed in the domicile or exaltation of that planet, the wise call that that gairikambüla configuration inauspicious.

An example of this [is given] in Samjjñätantra [2.58-6o]:

In the question 'Will I attain happiness?', Leo is the ascendant; the sun is in Aries with eight degrees; Mars, ruler of the fourth house, is in Aquarius with twelve degrees: there is an itthaśăla between them. The moon is in the last degree of Virgo; it lacks the dignities of domicile and so on, and has no itthaśála with any [planet, but will] form an 
sa svoccagena śaninānyarkșasthenetthaśälakrt | gairikambūlam anyena sāhāyyāl lābhadāyakam ||

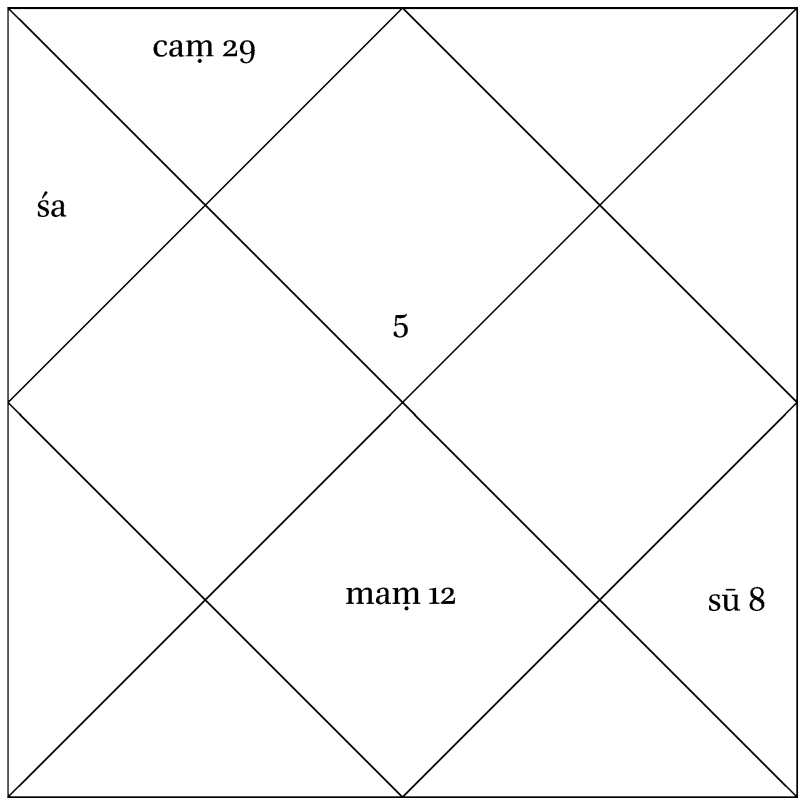

gairikambūlayogah

iti gairikambūlam \|

atha khallāsaraḥ | tatra tadyogalakṣaṇam āha yādavaḥ |

dvayor athaikena ca śítabhānur adrșțimārge vicaran karoti | na mūthaśílaṃ na ca saṃyutiṃ vā khallāsaraḥ kāryaharas tadā syāt ||

4 tad] khallāsara G K T M || āha] ā B 5 śîta ... mārge] śītabhānudṛ̦țị̣ svamārge B N

$5^{-6}$ dvayor ... syāt] TYS 6.27

41 While no exact position is given here, the accompanying figures in several text witnesses show Saturn at $12^{\circ}$ Libra. However, this would have the moon applying to the opposition of the sun before reaching the conjunction of Saturn. 
itthaśāla with Saturn occupying its exaltation in the next sign. ${ }^{41}$ [That] gairikambüla gives gain through the assistance of another.

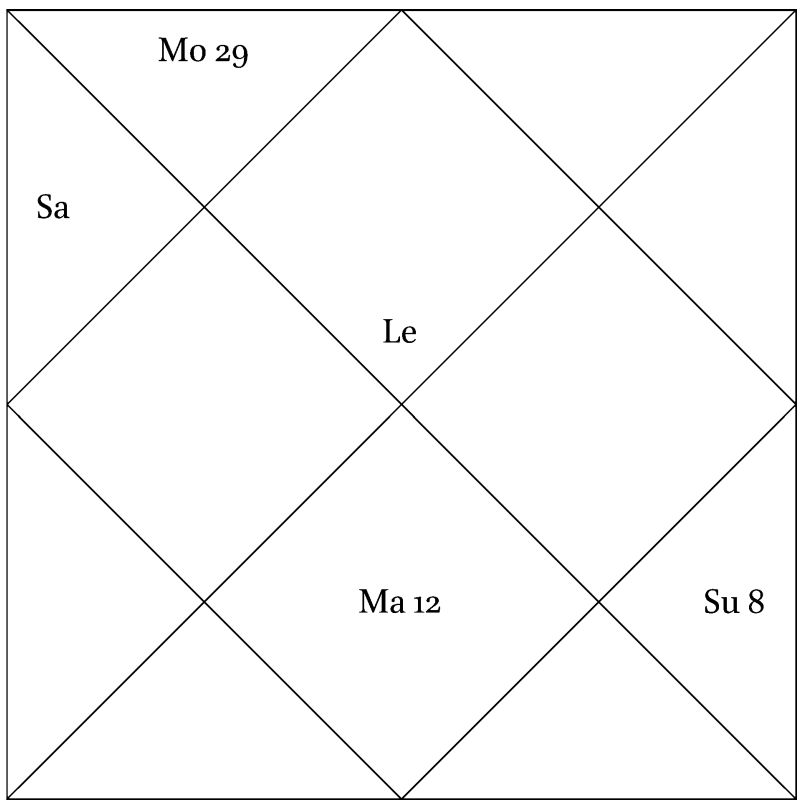

The gairikambüla configuration

This concludes the gairikambüla.

\subsection{The Khallāsara Configuration}

Next, the khallāsara; and Yādava states the definition of that configuration [in Täjikayogasudhānidhi 6.27]:

If the moon, traversing a path of no aspect with either of the two [planets], makes neither a mutthaśila nor a joining, then a khallāsara comes to be, destroying the matter sought. ${ }^{42}$

42 Here, Yādava apparently distinguishes between an itthaśāla or application on the one hand and a 'joining' or 'conjunction' (samyuti) on the other, though it is not clear what the difference is. Samyuti, a Sanskrit rather than Perso-Arabic term, might possibly refer to a conjunction by sign alone (without considerations of orbs of light), as used in pre-Islamic Indian astrology, or be meant to include separating conjunctions. 
atra lagneśakāryeśayor api mutthaśilābhāvo jñeya iti kecid āhus tan na | yatah sarvaiḥ khallāsaraphalaṃ kāryanāśakam ity uktam | tatra lagnapakāryapayor itthaśālābhāve kāryaprāptir eva na jātā | tatra kāryanāśasambhavaḥ khapuṣpādisamạ̣ | tayor itthaśāle kāryaprāptisambhave 'pi lagnapakāryapābhyāṃ candrasya yutītthaśālāsambhavāt kemadrumayogavad itthaśālaphalanāśakah khallāsarayogo jñeya iti | etat spaștam uktam jīrnatājike |

lagneśakāryādhipayor itthaśālo na vā yutih | dvābhyām candro netthaśālī proktah khallāsaro 'subhạ \|

udāharaṇam |

lapsye sutam iti praśne siṃhalagnaṃ raviḥ kriye | vedāṃśaih sutapo jīvaḥ kumbhe 'ṃśaiḥ śarasammitaih || lagnakāryapayor asti yogo muthaśilābhidhaḥ | atha kanyāntime 'miśe ca vidhur muthaśilo na hi | dvābhyāṃ ca tena kāryasya nāśí khallāsaro matah ||

1 tan na] tatra B 2 tatra] jïrṇatājake B; jïrsātājake $\mathrm{N} \quad 2-3$ lagnapa ... kāryapayor] lagneśakāryādhipayor B N K T M 3 eva] evaṃ B N || nāśa] om. K T M $\quad 4-5$ lagnapa] lagna G 5-6 yogavad itthaśāla] yoga*ād itthaśāla B; yogatthaśāla $N \quad$ 9-12 - ktaḥ ... jīvah $]$ om. B $\quad 11$ lapsye] laśye $\mathrm{N} \quad 12$ vedāṃśaiḥ] om. G \|| sutapo] sutapeḥ K T; sutape M 13 yogo] yo G 14 'ṃśe] om. G || muthaśilo] mūthaśile G T 
On this matter, some say that the absence of a mutthasila should be understood [to apply] to the ruler of the ascendant and the ruler of the matter sought as well, [but we say]: not so, for everyone declares the result of a khallāsara to be the destruction of the matter sought. But in the absence of an itthaśa la between the ruler of the ascendant and the ruler of the matter sought, the [possibility of] attainment of the matter sought does not even occur, and the possibility of the matter sought being destroyed is then like a flower in the sky and so forth. ${ }^{43}$ Even when there is an itthaśäla between them and [thus] the possibility of attaining the matter sought, when a joining [or] itthaśála with the ruler of the ascendant or the ruler of the matter sought is not possible for the moon, the khallāsara configuration, like the kemadruma configuration, should be understood to destroy the result of the itthaśála. ${ }^{44}$ This is clearly described in the Jìrnatājika:

[If there is] neither an itthaśăla nor a joining between the ruler of the ascendant and the ruler of the matter sought, and the moon forms an itthaśäla with neither, [that] is declared to be khallāsara, not good. ${ }^{45}$

An example:

In the question 'Will I have a child?', Leo is the ascendant; the sun is in Aries with four degrees; Jupiter, ruler of the fifth house, is in Aquarius with five degrees. There is the configuration called mutthasila between the rulers of the ascendant and of the matter sought. Then the moon is in the last degree of Virgo; [it has] no mutthaśila with the two [others]. Therefore a khallāsara, destroying the matter sought, is considered [to arise].

43 That is, an impossibility or absurdity.

44 Balabhadra's comparison is apt: the kemadruma-yoga described in pre-Islamic Sanskrit works on astrology (e.g. Brhajjätaka 13.3, 6) is a simpler version of the same idea, deriving its name from the Greek $\varkappa \varepsilon v o \delta \rho o \mu i \alpha$, which was later translated into Arabic as khalä' as-sayr and thus entered Sanskrit a second time as khallāsara. Both the Greek and the Arabic names refer to the moon moving in an 'empty path' or, in the traditional English phrase, being 'void of course' (translating the Latin vacua cursus).

45 But this quotation does support the position just refuted by Balabhadra, namely, that a khallāsara involves the lack of an itthaśála between the two relevant planets (in addition to the moon). 


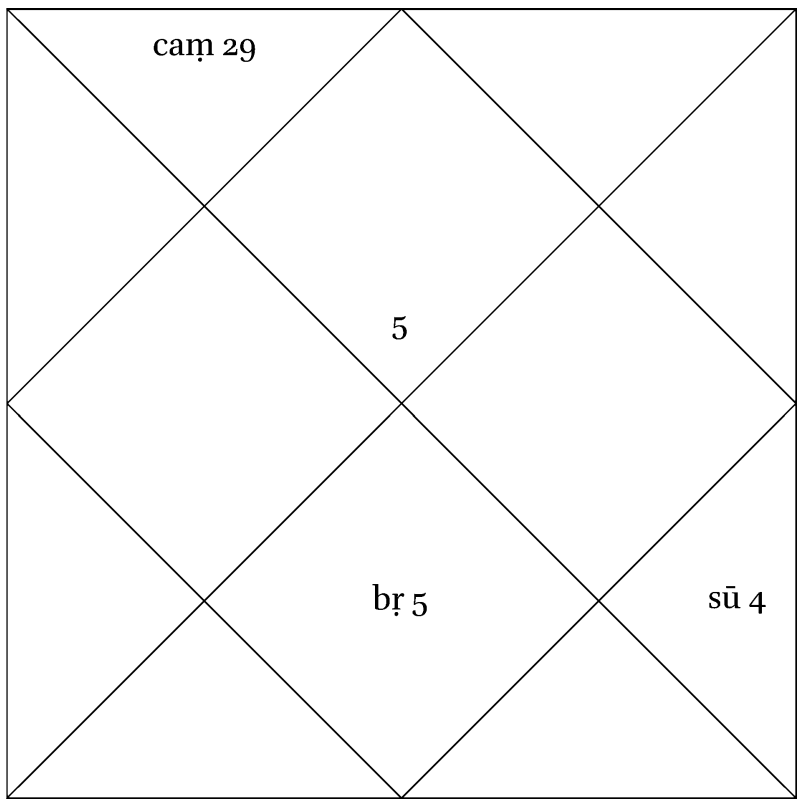

khallāsarayogah

iti khallāsarah \|

atha raddayogah | tatra raddayogalakṣaṇam uktam yogasudhānidhau |

vakreṇa dyumaṇikarābhigāmināstaṃ

prāptena vyayaripunāśagāminā ca|

krūreṇa kramitanabhahsadetthaśālam

tad raddam harati phalam praharșaṇīyam \|

atra viśeṣa uktas tājikabhūṣaṇe |

āpoklimasthaś carakhecaraś cet kendrasthamandena ca mūthaślam | karoti kārye prathamạ̣ vilambaṃ paścād avaśyam sakalārthasiddhị̣ \|

2 raddayogah] raddaḥ G 4 prāptena] prāptam na M 5 nabhaḥ] tabhas T; tamas M 8 āpoklimasthaś] āpoklimaś B N || khecaraś] khețaraś B N 9 siddhiḥ] siddhim K T M

3-6 vakreṇa ... praharșaṇīyam] TYS 6.28 8-9 āpoklimasthaś ... siddhih] TBh 4.26 


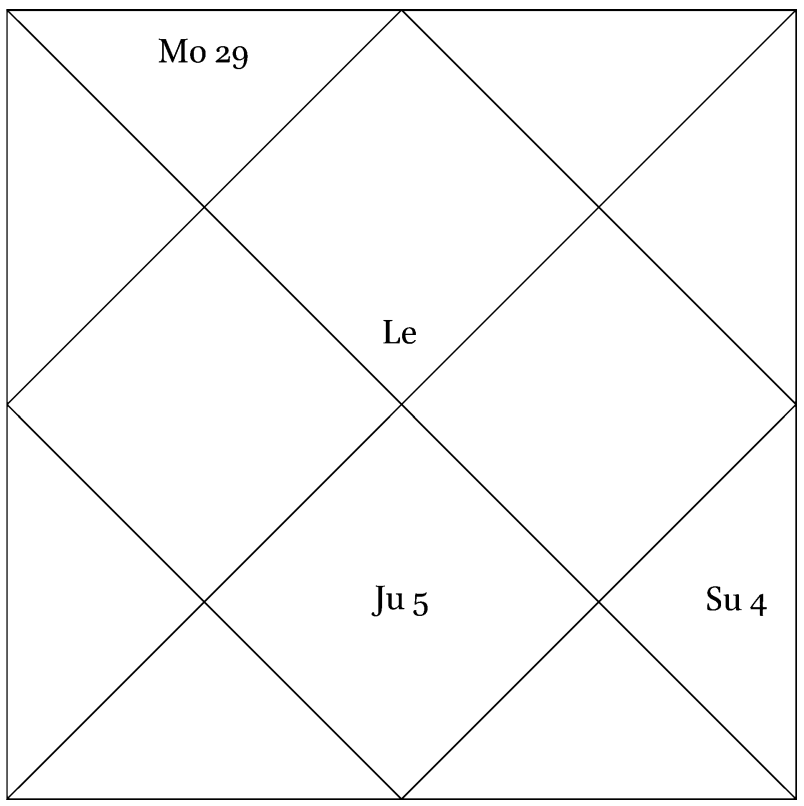

The khallāsara configuration

This concludes the khallāsara.

\subsection{The Radda Configuration}

Next, the radda configuration; and Yādava states the definition of a radda configuration in [Täjika]yogasudhānidhi [6.28]:

An itthaśāla with a planet that is retrograde, approching the sun's rays, [heliacally] set, occupying the twelfth, sixth or eighth house, or overcome by a malefic, is radda: it destroys delightful results. ${ }^{46}$

On this matter, a special rule is stated in Täjikabhūṣaṇa [4.26]:

If a swifter planet occupying a cadent house forms a mutthaśila with a slower one occupying an angle, at first there is a delay in the mat-

46 A punning allusion to the name of the somewhat unusual metre employed here: praharșiniı 'delighting'. 
kendrasthitạ síghragatih karoti

āpoklimasthena ca mūthaśilam |

mandena käryam prathamaṃ ca bhütvā

prānte vināśam samupaity avaśyam \|

atrodāharaṇam |

bhāgyapraśne meșalagnaṃ bhaumaḥ kanyāgato guruh |

bhāgyapas tatra tatraiva saṃsthitau ravimandagau |

sarve digamśapramitā raddo 'yaṃ phalanāśakah ||

vā tallagne mīnasamsthah kujo makarago guruh |

dvau digaṃśau prāg aśubhaṃ śubhaṃ paścāt prakīrtitam ||

vā tallagne karkasamstho bhaumo mīnagato guruh |

dvau digaṃśau prāk śubhaṃ syāt paścād aśubham eva ca ||

iti raddam $\|$

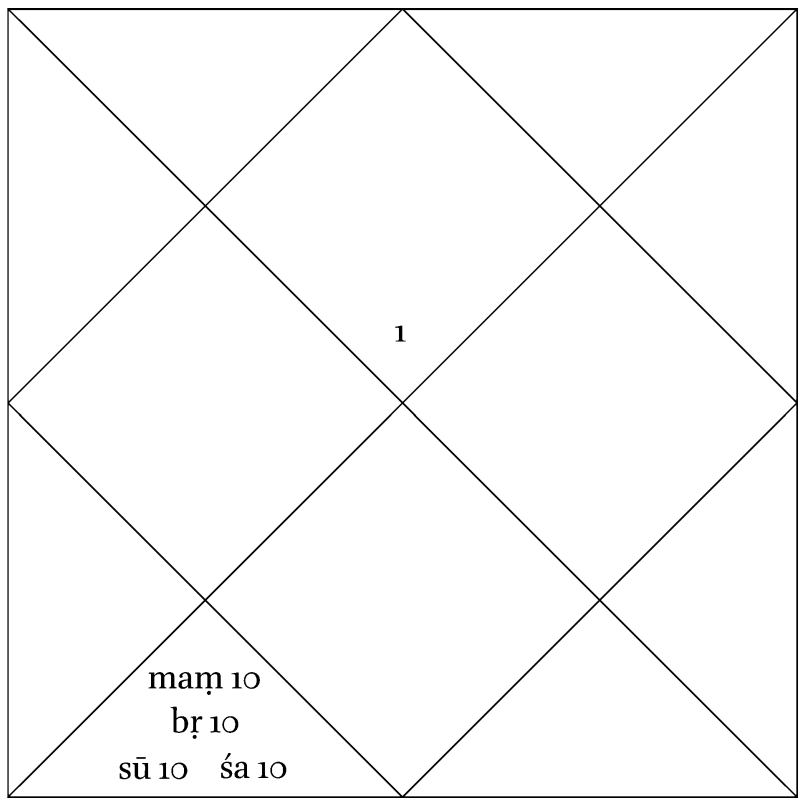

raddayogah phalanāśah

5 atrodāharaṇam] atrodāharaṇam add. K 10 digaṃśau] digaṃśa K T M 11 bhaumo] vā add. M $\|$ mīnagato] mīnato K M 12 syāt] om. B N; syā G 13 raddam] raddaḥ K T M 
ter sought, but afterwards inevitably success in all things. And if the swifter one, occupying an angle, forms a mutthaśila with a slower one occupying a cadent house, the matter sought, having first come into being, is inevitably destroyed in the end. ${ }^{47}$

Here is an example:

In a question on good fortune, Aries is the ascendant; Mars is in Virgo; Jupiter, ruler of the ninth house, is there [as well]; and there, too, are the sun and Saturn, all at ten degrees: this is radda, which destroys the [good] result.

Or, with that ascendant, Mars is in Pisces, Jupiter in Capricorn, both at ten degrees: first evil is declared, then good.

Or, with that ascendant, Mars is in Cancer, Jupiter in Pisces, both at ten degrees: first there will be good, and then evil.

This concludes the radda.

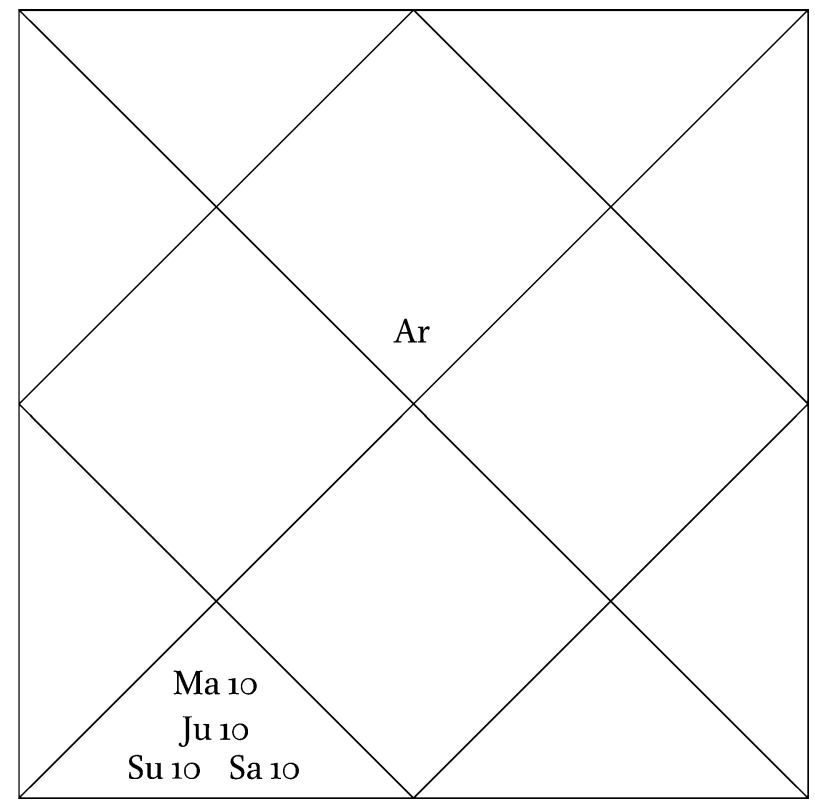

The radda configuration: destruction of results

47 The second sentence/stanza is not found in available text witnesses of the Täjikabhūṣaṇa. 


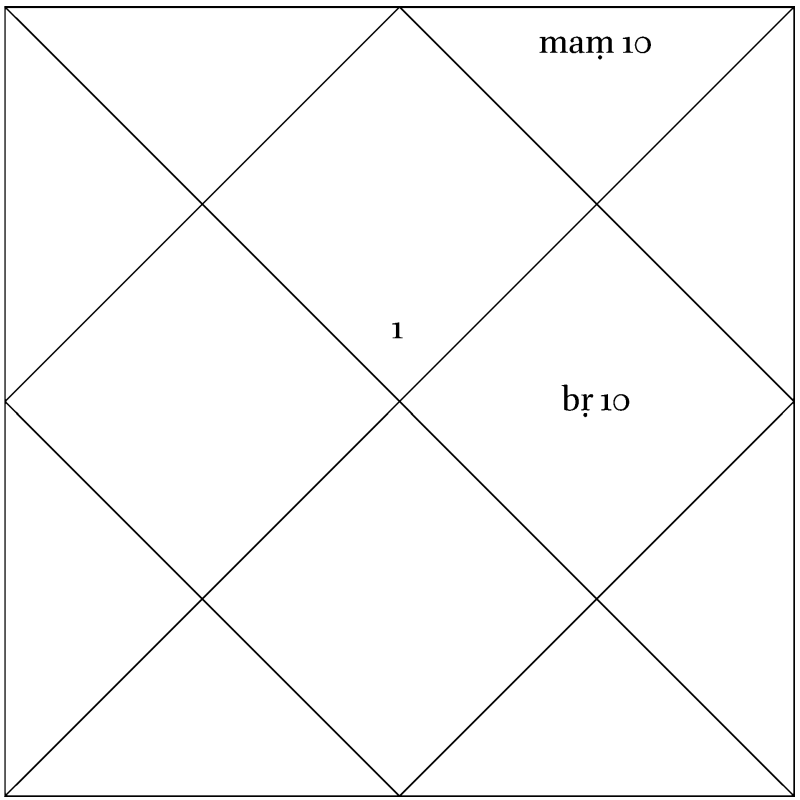

prāgaśubhapaścācchubharaddayogah

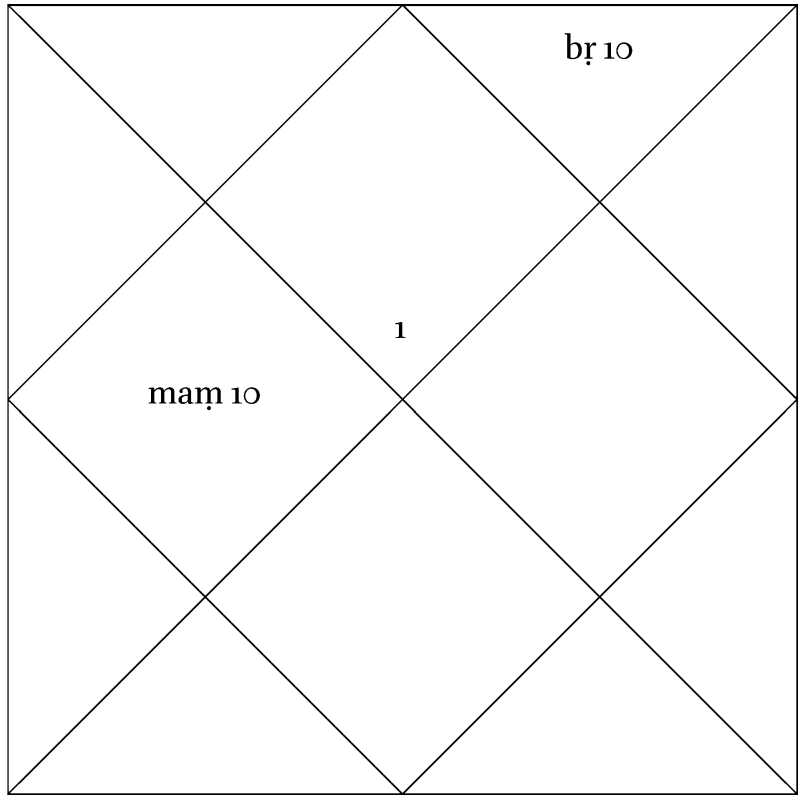

prākśubhapaścādaśubharaddayogạ̣ 


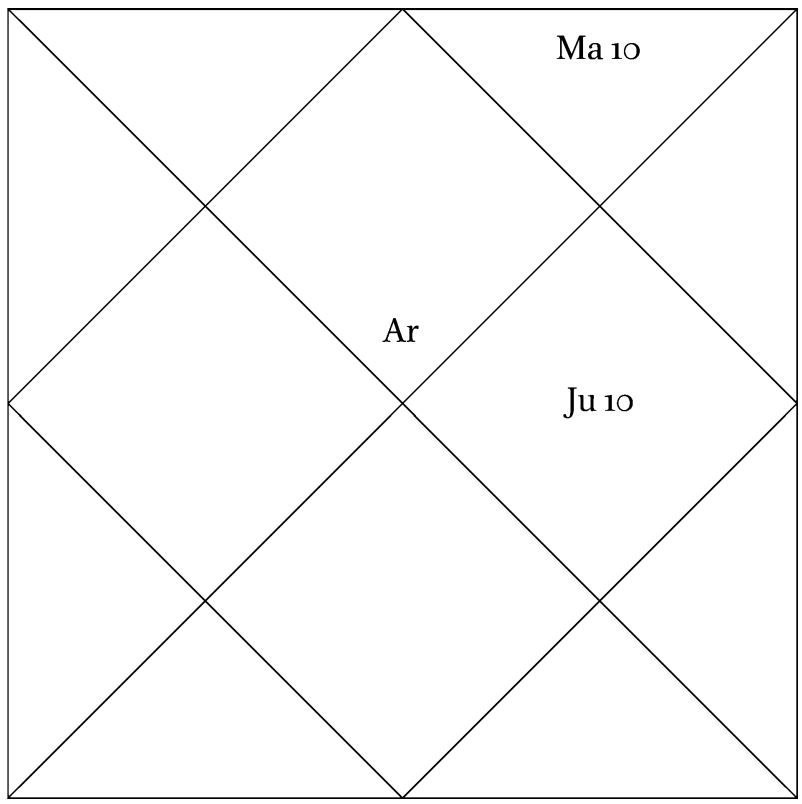

The radda configuration: first misfortune, then good fortune

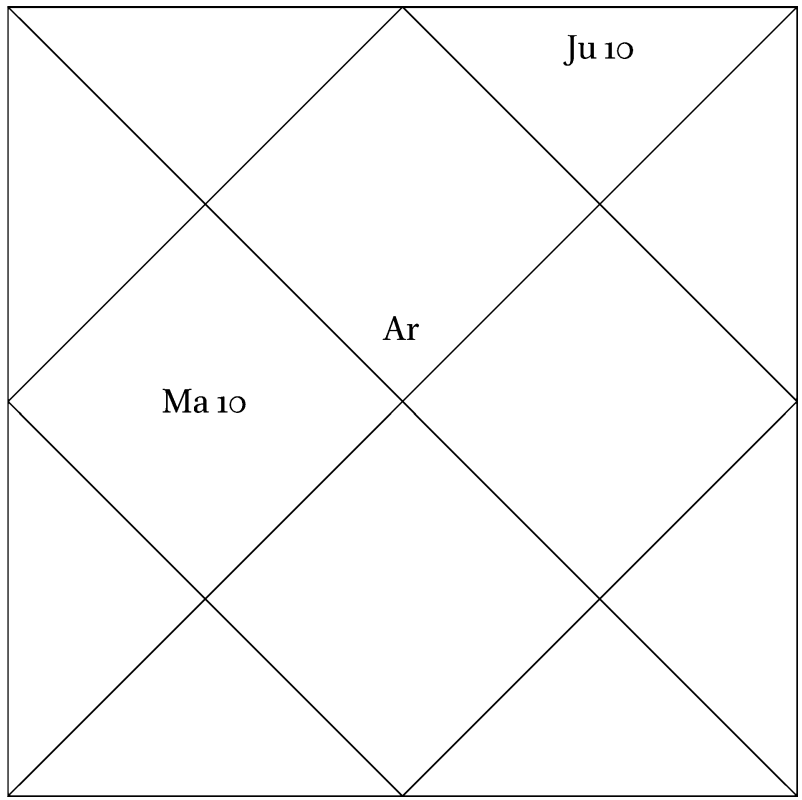

The radda configuration: first good fortune, then misfortune 
atha duḥphālikutthayogạ̣ | tatra duhphālikutthayogalakṣaṇaṃ tājikabhūṣaṇe |

mandaḥ svagehe yadi vā nijocce trairāśike vāpi nije prakuryāt | yogam carenānadhikāriṇā ced duhphālikutthah śubhakrn niruktaḥ \|

yogam muthaśilākhyam | yady adhikārarahitena śīghreṇa muthaśilaṃ 5 kāryakaraṃ tarhi adhikārasahitenāpy avaśyaṃ kāryakaram iti jīrṇațīkākṛt | atrodāharaṇam |

sukhapraśne meșalagnaṃ bhaumạ̣ sūryāṃśakaḥ kriye | digamśakah sukhādhīśo himāṃśuh kumbhasaṃsthitạ̣ | dvayor atretthaśālatvāt sukhalābhaṃ vinirdiśet ||

iti duhphpālikutthayogaḥ \|

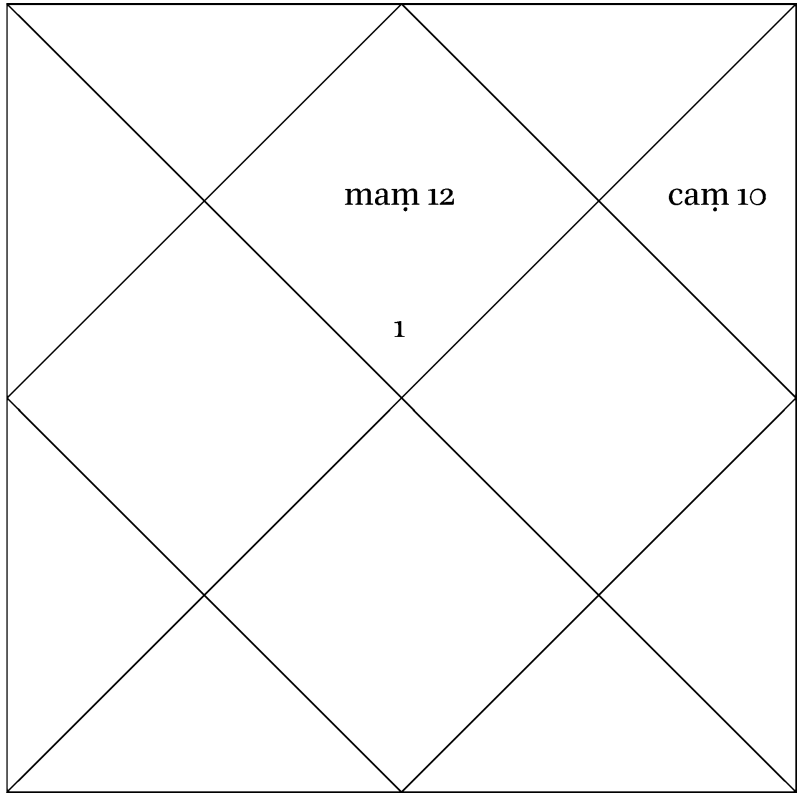

duhphālikutthayogaḥ

1 duhphpālikutthayogah | tatra] om. G 3 trairāśike] traiśike K 4 careṇānadhi] vareṇānadhi G 5 muthaśilam ] muśilaṃ G 6 jīnna] om. G 7 atrodāharaṇam] athodāharaṇam B N 11 duḥphālikutthayogaḥ] duḥphalālikuttha G; duḥphālikutthaḥ K T M

3-4 mandah ... niruktah] TBh 4.27 


\subsection{The Duhphālikuttha Configuration}

Next, the duhphālikuttha configuration; and the definition of a duhphälikuttha configuration [is stated] in Tājikabhūṣaṇa [4.27]:

If a slower [planet] in its own domicile or exaltation, or its own triplicity, should make a configuration with a swifter one with no dignity, [this] is declared to be the beneficent duhphälikuttha.

'A configuration', namely, a mutthaśila. If a mutthaśila with a swifter planet bereft of dignity will accomplish the matter sought, then [a mutthasila] with one that has dignity will necessarily accomplish the matter: so says the ancient commentator. Here is an example:

In a question on happiness, Aries is the ascendant; Mars is in Aries at twelve degrees; the moon, ruler of the fourth house, occupies Aquarius at ten degrees. By the two forming an itthaśāla, one should predict the attainment of happiness.

This concludes the duhphālikuttha configuration.

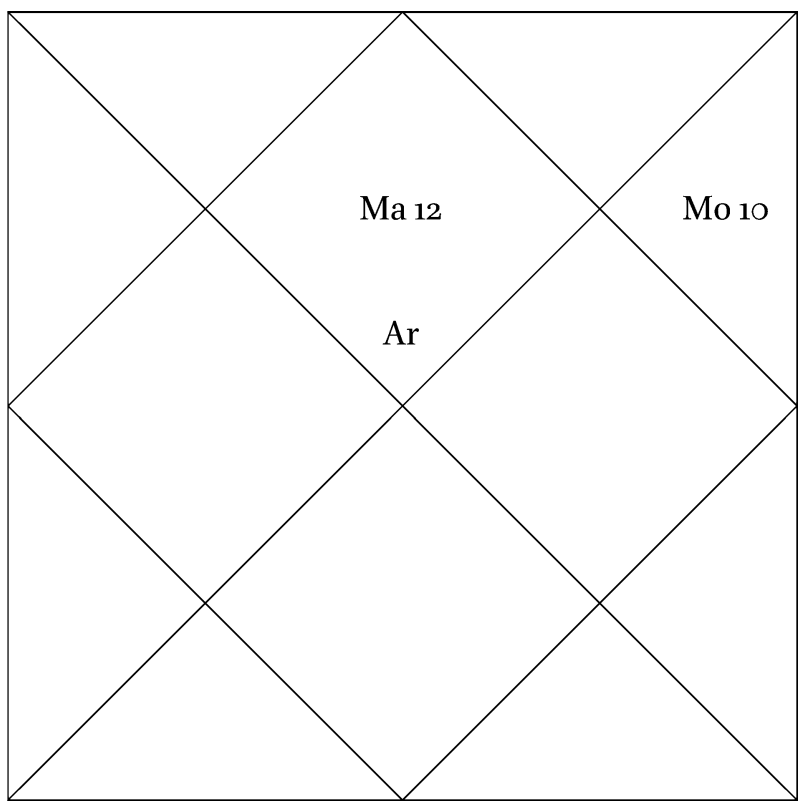

The duhphälikuttha configuration 
atha dutthotthadabīrayogah | tatra dutthotthadabīrayogalakșaṇam uktam jīrṇatājike |

lagneśakāryādhipatī nirbalau yogakārakau| tayor ekah svagehoccādisthenānyena yogakrt \|| dutthadabbïrayogo 'nyasāhāyyāt kāryakārakaḥ|

athavānyau grahau svarkṣādigau síghragatī tayoḥ \|

nirbalena ca mandena muthaśilakarau tadā |

dutthadabbīrayogo 'nyasāhāyyāt kāryakārakah \|

tayor lagneśakāryeśayoḥ | udāharaṇam |

jāyāpraśne siṃhalagnaṃ tulāsaptāṃśake raviḥ | śanir meșe nandabhāgaḥ kujo meșe rasāṃśakah \| nirbalau lagnakāryeśāv itthaśālakarau tayoḥ | śanih svag̣̣hasaṃsthena bhaumena muthaśillakṛt | jāyālābho 'nyasāhāyyād dutthadabbīrayogake || vā tallagne sūryabhaumamandāḥ pūrvoktavat sthitāḥ | meșe jīvaḥ svahaddāyāṃ pañcāṃśo gurubhūmijau | mandena yogakartārāv ato lābho 'nyatah smṛtah ||

1 -dabīra ${ }^{1}$ ] -taṃbīra M || -dabīra²] -taṃbīra M || uktaṃ] uñ K 5 -dabbīra] -taṃbīra M || sāhāyyāt] sāyyāt T \| kārakaḥ] kāraḥ B N; karaḥ G 8 -dabbīra] -taṃbīra M || kārakaḥ] karah G 11-12 śanir ... tayoh] om. N 13 sampsthena] saṃstho na $G \quad 14$ yogake] yogakau B; yogakauh N 15 vat] va B 16 bhūmijau] bhūmijạ̣ M 
Next, the dutthotthadabira configuration; and the definition of a dutthotthadabira configuration is stated in the Jìrnatājika:

[If] the ruler of the ascendant and the ruler of the matter sought, being weak, form a configuration, and one of them [also] forms a configuration with another [planet] occupying its own domicile, exaltation and so forth, [that is] dutthotthadabira, accomplishing the matter sought through the assistance of another.

Or else, if two other, swifter planets, occupying their own domiciles and so forth, form a mutthaśila with the slower, weak one of the two, then [that, too, is] dutthotthadabira, accomplishing the matter sought through the assistance of another.

'Of the two' [means] of the ruler of the ascendant and the ruler of the matter sought. An example:

In a question on [finding] a wife, Leo is the ascendant; the sun is the seventh degree of Libra; Saturn is in Aries at nine degrees; Mars is in Aries at six degrees. The rulers of the ascendant and the matter sought, forming an itthaśăla, are weak, [but] of the two, Saturn forms a mutthaśila with Mars, which occupies its own domicile. In [this] dutthotthadabira configuration, the obtainment of a wife [comes about] through the assistance of another.

Or, in the same ascendant, the sun, Mars and Saturn are placed as already stated; Jupiter is in its own haddā in Aries at five degrees. Jupiter and Mars form a configuration with Saturn; therefore, [a wife] is said to be obtained through another. 


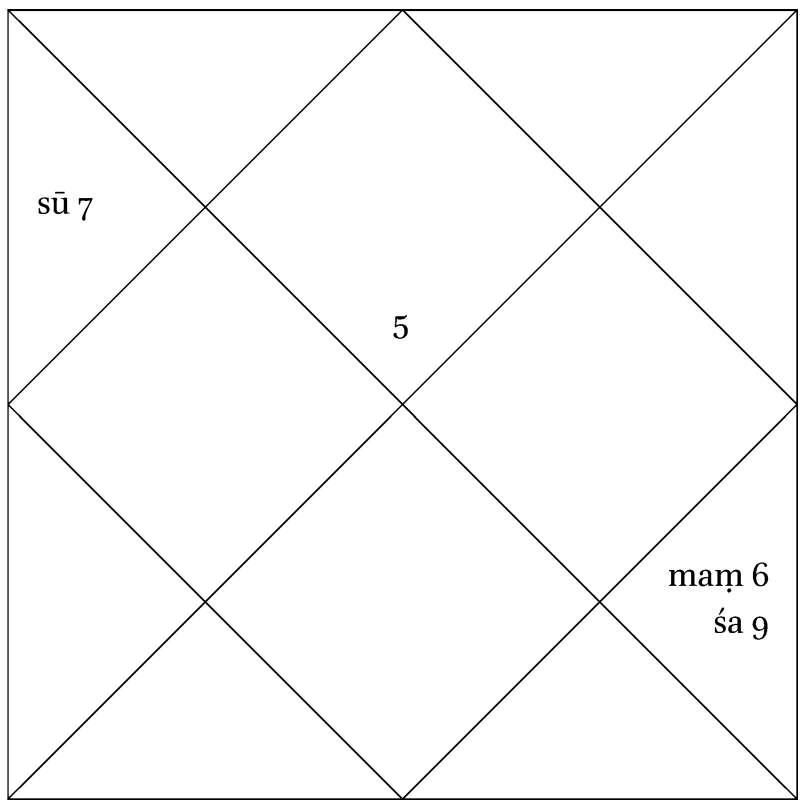

dutthotthadabīrayogạ

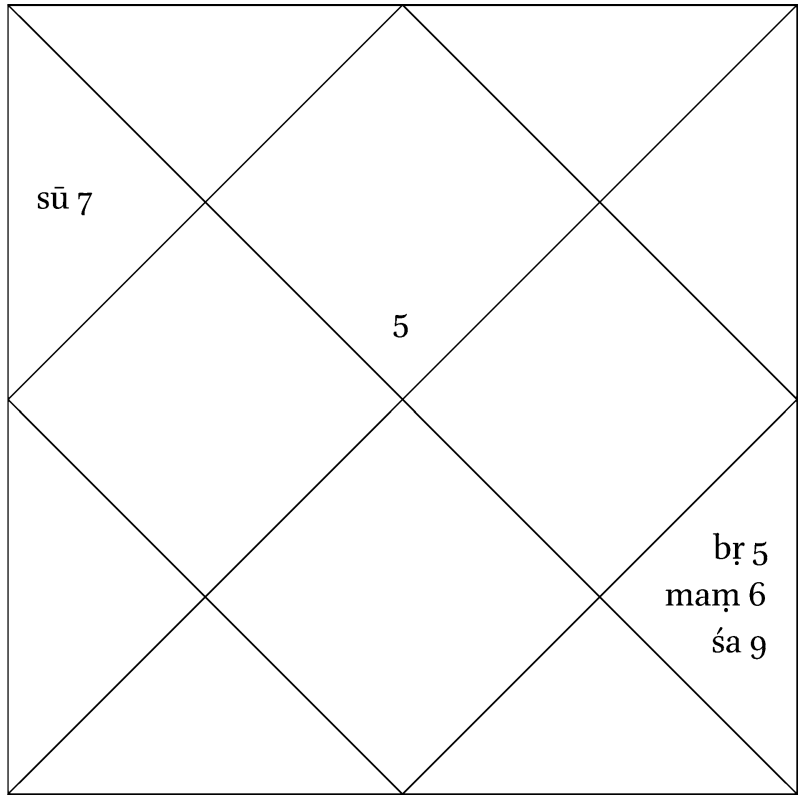

dutthotthadabīrayogah 


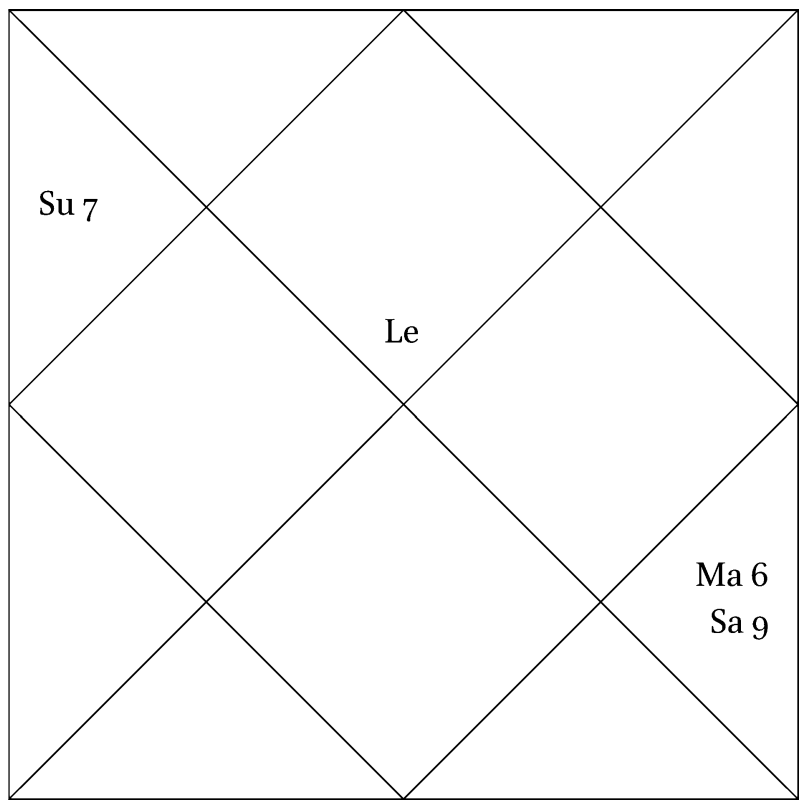

The dutthotthadabira configuration

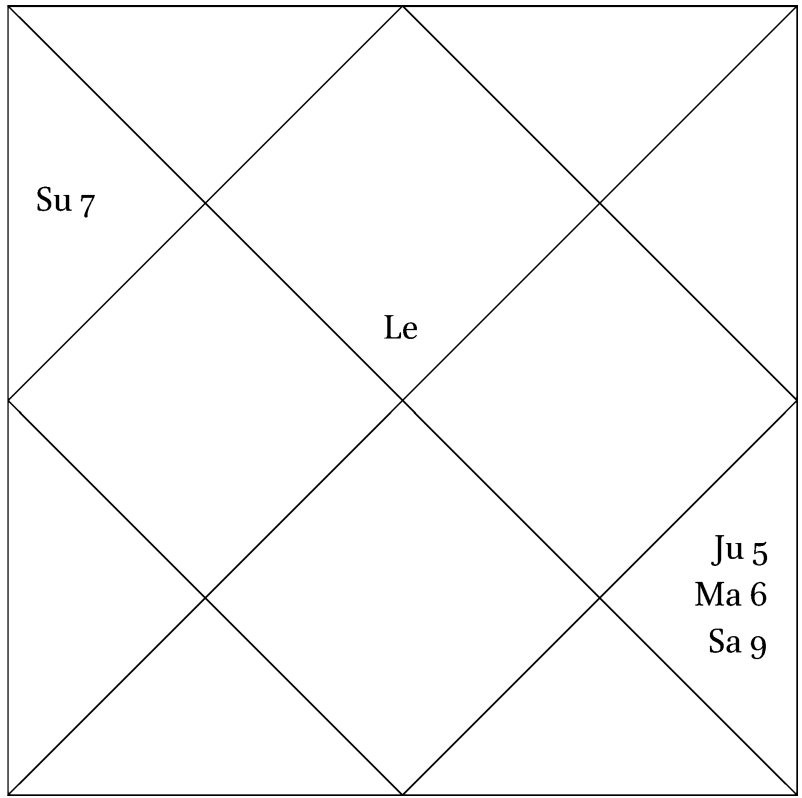

The dutthotthadabira configuration 
atra svagṛhago bhaumạ svahaddāstho gurus tau svanīcasthena nirbalaśanaiścareṇetthaśālakarāv atạ strīlābho 'nyato vācyaḥ | iti dutthotthadabīrayogah ||

atha tambīrayogaḥ | tatra tambīrayogalakșaṇam uktaṃ hāyanasindhau |

lagneśakāryādhipayor nayogo balì tayor bhāntagato 'parāya |

dīptāṃśakair virryayutāya datte 'nyarkșe maho 'tyantaśubhas tabīraḥ ||

atra lagneśakāryeśayor itthaśālābhāve tayor eko balī rāśyantagah aparāya anyasmai svag̣̣hādivīryayutāyāgrimarāsaāv itthaśāladvārayā tejo datte | sa śubhas tambīrayogah | udāharaṇam |

sukhapraśne tulālagnaṃ dvyaṃśạ̣ karke bhṛguḥ śanị̣| ekonatriṃśadaṃśaś ca kumbhe yogas tayor na hi \|| mīnasaṃsthena guruṇā pañcāṃśenetthaśālavān | śanis tambīrayogo 'yaṃ proktạ̣ kāryakaro budhaih ||

1 gṛhago] gṛhagau B N; grahago M 2-3 dutthotthadabīra] dutthodabīra G; dutthotthatambīra M $\quad 7$ itthaśāābhāve] iśālābhāve $\mathrm{K} \quad 8$ anyasmai] vīryayutāya datte 'nyarkṣe maho 'tyaṃtaśubhas tabīrah atra lagneśakārye add. G \|| sva ... yutāyāgrima] agrima G 11 yogas tayor] yogonayor B N; yogo tayor K T M 13 budhaih] budhạ̣ B N 
Here, Mars is in its own domicile; Jupiter is in its own haddā. The two form an itthaśála with the weak Saturn placed in its fall; hence the obtainment of a wife through another [person] should be predicted. This concludes the dutthotthadabira configuration.

\subsection{The Tambira Configuration}

Next, the tambira configuration; and the definition of a tambira configuration is stated in the Hãyanasindhu:

[If] there is no configuration between the ruler of the ascendant and the ruler of the matter sought, [but one] of them, strong and placed at the end of a sign, gives its light to a different [planet] endowed with strength in the next sign, within its orb of light, [that is] the exceedingly beneficial tambira.

Here, in the absence of an itthaśála between the ruler of the ascendant and the ruler of the matter sought, one of them, strong and placed at the end of a sign, by means of an itthaśăla gives its light to a different, [that is], another [planet], endowed with the strength of [occupying] its own domicile and so forth, in the following sign. That is the beneficial tambira configuration. An example:

In a question on happiness, Libra is the ascendant; Venus is in Cancer at two degrees, and Saturn is in Aquarius at twenty-nine degrees. There is no configuration between them, [but] Saturn forms an itthaśäla with Jupiter placed in Pisces at five degrees. This is declared by the wise to be a tambira configuration, accomplishing the matter sought. ${ }^{48}$

48 The scenario described could be an itthaśála, that is, an applying conjunction, only if Jupiter were retrograde or stationing to retrograde, in which case Saturn would most likely be retrograde as well. Jupiter would then re-enter Aquarius, rather than Saturn entering Pisces. Such a scenario is astronomically compatible with Venus being placed in Cancer, but it seems unlikely that this was what Balabhadra had in mind. 


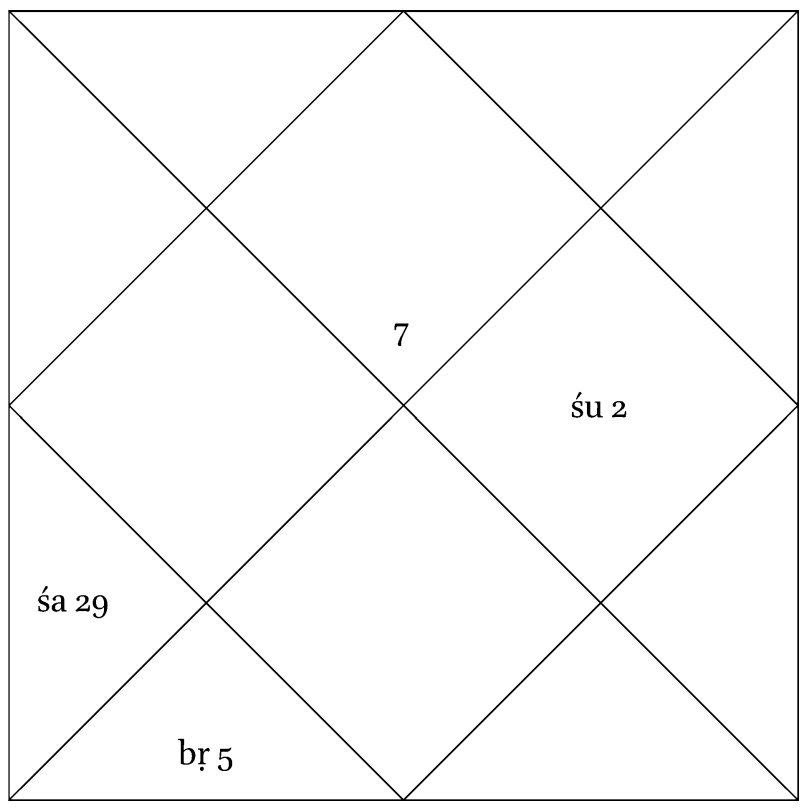

tambīrayogah

iti tambīrayogaḥ ||

atha kutthayogaḥ | tatra kutthayogalakṣaṇam uktam tājikabhūṣaṇe |

khețah svīyagrhādikanțakagatah präglagnasaṃlagnadṛk sadbhir drștayutaś ca pāpayutidṛsamvvarjito 'bhyudgatah | mārgī kālabalānvitah sa balavān samyakphalāvāptidặ kālajñair balavīkșaṇāya gadito yogo hi kutthābhidhạ̣ \|

iti kutthạ \|

1 tambīrayogaḥ] taṃbīrạ̣ $\mathrm{G} \quad 3$ prāg] prāga $\mathrm{K}$ T 4 sadbhir dṛșța] sadbhidarșța N || 'bhyudgatah] bhyudgamạ K T M

3-6 khețah ... ābhidhah] TBh 4.29a

3-6 khețah ... äbhidhah] This stanza is missing from the printed edition of the TBh, where it should occur between vv. 4.29 and 4.30, but present in MS TBh. 


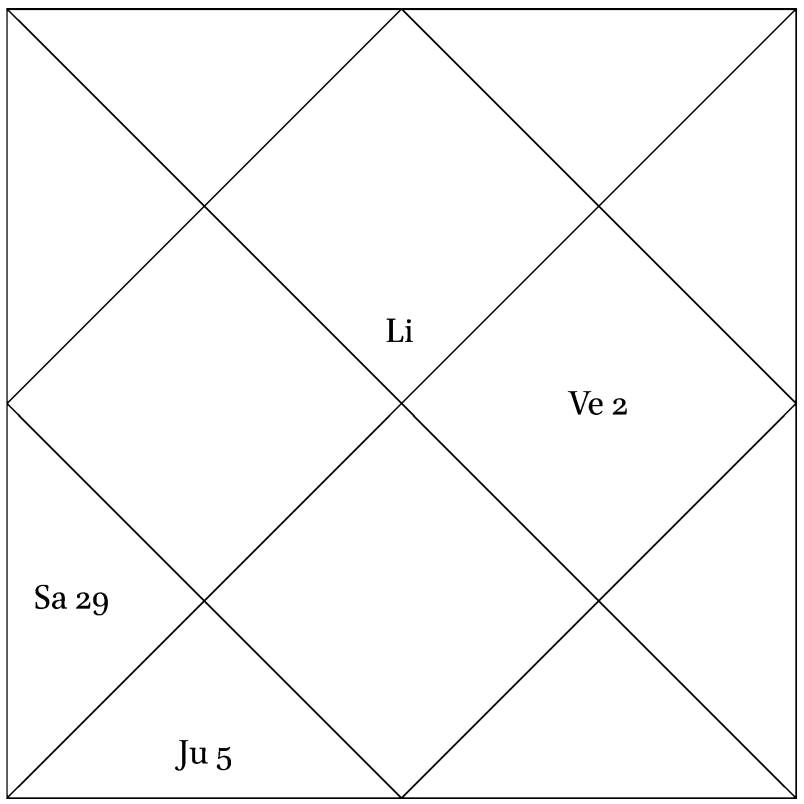

The tambira configuration

This concludes the tambira configuration.

\subsection{The Kuttha Configuration}

Next, the kuttha configuration; and the definition of a kuttha configuration is stated in Täjikabhūṣaṇa [4.29 $]$ :

A planet occupying its own domicile and so on, in an angle, conjunct or aspecting the ascendant, conjunct or aspected by benefics, free from the conjunction and aspect of malefics, [heliacally] risen, direct, possessed of strength by time, is strong and grants the attainment of results in full. [This] configuration, called kuttha, is declared by astrologers for ascertaining the strength [of a planet].

This concludes the kuttha. 
atha duruḥphayogaḥ | tatra duruḥphayogalakșaṇaṃ tatraiva |

astamgato vyastagatis tv aśastair yutekșito 'ștāntyarigah svagehāt | saptopago nīcakhagetthaśáli rāhvāsyapucche duruphäbhidhānaḥ \|

samjjñātantre candrasya duruḥphe viśeșa uktaḥ |

candrah sūryād dvādaśe vrścikādye khaṇde neșțo 'ntye tulāyāṃ viśeșāt |

rāsiśsenādrșțamūrtir na sarvair dṛșto jñeyah śūnyamārgaḥ padonah \||

kșine bhānte no śubho janmakāle prcchāyām vā candra evaṃ vicintyaḥ | śukle bhaumah krșnapakșe 'rkasūnuḥ kșuddrștyendum vīkșate no śubho 'sau \|

asyāpavādam āha samarasiṃhaḥ|

divase tu pūrvapakṣe prcchāyām jātake ca ravisūnuḥ| nararāsígo 'lpadoșaṃ bahudoṣam vyatyayāt kurute \| bhaumo rātrāv apare pakṣe strīrāsisisạngatah svalpam| doșaṃ kurute praśne janmani ca vyatyayāt pracuram \|

iti duruḥphạ ||

2 gatis] gamis B N || 'șțāntyarigah] șțāṃtyārigaḥ B; 'ștāṃtyādiragaḥ N; șțāṃtyārigas K M 3 saptopago] samopago $\mathrm{N} \quad 4$ viśeșa uktaḥ] viśeșoktaḥ B N G K T 6 rāśíśenādṛșta] rāśîśena dṛșta N 7 kṣiṇe] kṣinno N $\|$ kṣiṇe bhānte] kṣinnaś caṃdro G T 8 pakṣe 'rka] parkekṣai N \| vīkṣate] vīkṣyato B N; vīkṣyate K T \| śubho 'sau] śubhāsau B 11 vyatyayāt] vityayāt B N 12 rātrāv apare] rātrāpare $\mathrm{B} \mathrm{N}$

2-3 astaṃgato ... ābhidhānah] TBh 4.30 $\quad 5^{-8}$ candrah ... 'sau] ST 2.73-74 $\quad 10-13$ divase ... pracuram] TŚ

2 'ștāntyarigah svagehāt] For metrical reasons, -anty- (for a non-standard stem form antin) must be accepted here in the sense of antya. Independent text witnesses of the TBh read randhragrhādisamsthah. 
Next, the duruhpha configuration; and the definition of a duruhpha configuration [is stated] in the same place [Tājikabhūṣaṇa 4.30]:

[If a planet is heliacally] set, retrograde, conjunct or aspected by malefics, occupying the eighth, twelfth or sixth house, placed in the seventh [sign] from its domicile, forming an itthaśâla with a fallen planet [or] in the mouth or tail of Rāhu, [that configuration] is called duruhpha.

A special rule on the duruhpha of the moon is stated in Samjñätantra [2.73$74]: 49$

The moon is not good in the twelfth [sign] from the sun; in the former half of Scorpio and the latter [half] of Libra in particular; unaspected by the ruler of its sign; unaspected by anyone, known as being in an empty path, ${ }^{50}$ without dignity; nor is it good when waning [or] at the end of a sign, whether at the time of the nativity or in a question: thus should the moon be judged. [If] Mars in the bright or Saturn in the dark fortnight aspects the moon with a kșut aspect, it is not good.

Samarasiṃha states an exception to this [in the Täjikaśāstra]:51

In the daytime and in the former [bright] fortnight, in a nativity or a question, Saturn placed in a male sign does little harm, but much harm if the opposite. Mars at night, in the latter fortnight, and placed in a female sign, does little harm in a nativity or a question, but much if the opposite.

This concludes the duruhpha.

49 This 'special rule' is based on the sixteenth and last condition in Sahl's original list: ahwāl al-qamar 'the [harmful] conditions of the moon', separate from duff 'weakness'; see the Introduction.

$5^{\circ}$ Here a Sanskrit expression is used for what was treated as a separate configuration in 3.10. Cf. note 44 .

$5^{1} \quad$ But the quotation from Samarasimha is not so much an exception as an elaboration of what was just said. The distinctions made here between day and night, odd and even signs, and the waxing and waning phases of the moon, are based on the Hellenistic concept of sect, not well understood in Tājika tradition. 
ete sarve itthaśālasyaiva bhedā ity uktaṃ ca yādavena |

tam tạ̣ viśeșam pratipadyamāno nirūpitaḥ șoḍaśadhetthaśālạ̣| yathā caturvimiśatibhedaśālì syāt keśavaś cakragadādibhedaih ||

anyo 'pi viśeșas tatraiva |

yadyadbhāvapatir dadāti hi nijaṃ tejo 'ñganāthāya cet

tattatprāptikaro 'nyathā kṣayakaraḥ krūraḥ śubhārdhāptikrt |

evam krūraśubhādivīkșaṇavaśāj jñātvā vaded buddhimān

bhāgair antarasambhavai raviguṇais tatprāptikālam tathā $\|$

iti śrīmaddaivajñavaryapaṇḍitadāmodarātmajabalabhadraviracite hāyanaratne șoḍaśayogādhyāyas tṛtīyah $\|3\|$

\footnotetext{
1 bhedā] bhedaḥ B N $\quad 2$ tam² ${ }^{2}$ om. B N || șoḍaśadhetthaśālaḥ] ṣoḍaśadyetthaśālataḥ B N 3 śâlī syāt] śīlāsya B N 5 patir] papatir B 6 tat $^{2}$ ] om. N \|| subhārdhāpti] śubharddhyāpti $\mathrm{M}$

2-3 tam $^{1} \ldots$ bhedaih] TYS $6.34 \quad 5^{-8}$ yad $^{1} \ldots$ tathā] TYS 6.35
} 
Yādava says [in Täjikayogasudhānidhi 6.34] that all these [configurations] are simply subdivisions of itthaśála:

[Thus] itthaśāla has been described in sixteen ways, by setting forth this or that distinction, just as Keśava has twenty-four distinct forms, distinguished by [the hands in which he holds] the discus, mace and so on. ${ }^{52}$

Another special rule [is found] in the same place [Täjikayogasudhānidhi 6.35]:

Whichever ruler of a house gives its own light to the ruler of the ascendant, it effects the attainment of [the signfications of] that [house], or else its destruction: a malefic effects half the attainment [bestowed by] a benefic. Understanding it thus, in accordance with the aspects of malefics and benefics and so on, the wise should likewise predict the time of attaining that [result] from the intervening degrees [in the itthaśála] multiplied by twelve. ${ }^{53}$

In the Hāyanaratna composed by Balabhadra, son of the learned Dāmodara, foremost of astrologers, this concludes the third chapter: the sixteen configurations.

$5^{2}$ These are the so-called upavyūhas or secondary manifestations of Viṣnu in Vaiṣnava Pāñcarātra doctrine, each known by a different name.

53 Cf. note 18. 